


\section{Agrarische productie ten behoeve van de korte keten. Een landelijke meting}

Gabe Venema, Mariël Benus, Walter van Everdingen, Linda Puister-Jansen, Gerben Splinter, Marcel Vijn, Dominique van Wonderen

Dit onderzoek is uitgevoerd door Wageningen Economic Research en gesubsidieerd door het ministerie van Landbouw, Natuur en Voedselkwaliteit, in het kader van het Beleidsondersteunend onderzoeksthema 'Duurzame voedselvoorziening \& -productieketens \& Natuur' (projectnummer BO-43-014.01-066)

Wageningen Economic Research

Wageningen, juni 2021

RAPPORT

2021-067

ISBN 978-94-6395-852-3 
Gabe Venema, Mariël Benus, Walter van Everdingen, Linda Puister-Jansen, Gerben Splinter, Marcel Vijn, Dominique van Wonderen, 2021. Agrarische productie ten behoeve van de korte keten. Een landelijke meting. Wageningen, Wageningen Economic Research, Rapport 2021-067. 58 blz.; 7 fig.; 10 tab.; 7 ref.

Afzet van agrarische producten via korte ketens wordt in toenemende mate door beleid en markt gezien als een middel om te komen tot nieuwe verdienmodellen voor agrarische ondernemers en tot versterking van de verbinding tussen de producerende ondernemers en burgers. De in dit rapport gepresenteerde nulmeting geeft inzicht in de afzet van producten via korte ketens in agrarische sectoren in 2020. Op nationaal niveau wordt inzicht gegeven in aantallen korteketenbedrijven, kenmerken van deze bedrijven en een schatting van de omzet via afzet van producten via korte ketens. Ook wordt in hoofdlijnen ingegaan op korte ketens in de provincies, met een samenvattend overzicht van aandachtspunten voor verdere stimulering van korte ketens. Een beschrijving van de situatie per provincie is te vinden in aparte factsheets per provincie.

Policy makers and markets increasingly view the sales of agricultural products through short chains as a way to create new revenue models for agricultural entrepreneurs and to strengthen the relationship between producers and citizens. The baseline measurement presented in this report offers insight into the sales of agricultural products through short chains in agricultural industries in 2020 . On a national level, insight is given into the number of short-chain enterprises, the characteristics of these businesses and an estimate of the turnover as a result of short-chain product sales. Also, an outline is given of short chains in the provinces with a summary overview of focus points for further promotion of short chains. The situation for each province is described in separate factsheets.

Trefwoorden: Korte keten bedrijven, monitoring, land- en tuinbouw, bedrijfskenmerken, opbrengsten

Dit rapport is gratis te downloaden op https://doi.org/10.18174/548279 of op www. wur.nl/economicresearch (onder Wageningen Economic Research publicaties).

(C) 2021 Wageningen Economic Research

Postbus 29703, 2502 LS Den Haag, T 07033583 30, E communications.ssg@wur.nl, www.wur.nl/economic-research. Wageningen Economic Research is onderdeel van Wageningen University \& Research.

\section{(cc) BY-NC}

Dit werk valt onder een Creative Commons Naamsvermelding-Niet Commercieel 4.0 Internationaallicentie.

(C) Wageningen Economic Research, onderdeel van Stichting Wageningen Research, 2021

De gebruiker mag het werk kopiëren, verspreiden en doorgeven en afgeleide werken maken. Materiaal van derden waarvan in het werk gebruik is gemaakt en waarop intellectuele eigendomsrechten berusten, mogen niet zonder voorafgaande toestemming van derden gebruikt worden. De gebruiker dient bij het werk de door de maker of de licentiegever aangegeven naam te vermelden, maar niet zodanig dat de indruk gewekt wordt dat zij daarmee instemmen met het werk van de gebruiker of het gebruik van het werk. De gebruiker mag het werk niet voor commerciële doeleinden gebruiken.

Wageningen Economic Research aanvaardt geen aansprakelijkheid voor eventuele schade voortvloeiend uit het gebruik van de resultaten van dit onderzoek of de toepassing van de adviezen.

Wageningen Economic Research is ISO 9001:2015 gecertificeerd. 


\section{Erratum bij Rapport 2021-067}

29 juli 2021

Pagina 21, onderaan:

De daaruit voortkomende verhoudingsfactor is vermenigvuldigd met de berekende SO per bedrijf in 2020 (dit is per bedrijfstype toegepast) om tot een zo goed mogelijke indicatie te komen van de werkelijke opbrengsten in 2020.

Wordt:

De daaruit voortkomende correctiefactor is vermenigvuldigd met de berekende SO per bedrijf en het $\%$ opbrengsten korte keten per bedrijf in 2020 (dit is per bedrijfstype toegepast) om tot een zo goed mogelijke indicatie te komen van de werkelijke opbrengsten korte keten in 2020.

Pagina 35, tabel 3.6:

De omzet overig tuinbouw is 209 miljoen euro, in plaats van 2.096 miljoen euro. 


\section{Addendum bij Rapport 2021-067}

29 juli 2021

Samenvatting pagina 7 midden:

De totale opbrengsten door verkoop via korte ketens op agrarische bedrijven gerepresenteerd in de Landbouwtelling wordt geschat op minimaal 1,359 miljard euro.

Wordt:

De totale opbrengsten door verkoop via korte ketens op agrarische bedrijven gerepresenteerd in de Landbouwtelling wordt geschat op minimaal 1,359 miljard euro over de periode april $2019 \mathrm{t} / \mathrm{m}$ maart 2020.

Engelse vertaling, pagina 11:

The total revenue from sales via short chains among the agricultural companies listed in the Agricultural Census is estimated at a minimum of $€ 1359$ billion

\section{Becomes:}

The total revenue from sales via short chains among the agricultural companies listed in the Agricultural Census is estimated at a minimum of $€ 1359$ billion a year ( 1 April 2019 to 31 March 2020)

Pagina 34, 3.6.3 Totale omzet via korte ketens - $2^{\mathrm{e}}$ alinea:

De totale opbrengsten uit afzet van voedings- en sierteeltproducten op agrarische bedrijven worden geschat op 1,359 miljard euro. Dit is gebaseerd op de bedrijven die vertegenwoordigd zijn in de Landbouwtelling 2020.

Wordt:

De totale opbrengsten uit afzet van voedings- en sierteeltproducten op agrarische bedrijven worden geschat op 1,359 miljard euro. Dit is gebaseerd op de bedrijven die vertegenwoordigd zijn in de Landbouwtelling 2020, en betreft de periode april 2019 t/m maart 2020 (in het vervolg wordt deze twaalf-maandelijkse periode als opbrengsten 2020 bestempeld).

In het rapport wordt meerdere keren verwezen naar de plaats van de factsheets per provincie op agrimatie.nl. Deze link is nu nader gepreciseerd naar het thema korte keten in beeld (indicator korte keten) op agrimatie.nl.:

https://www.agrimatie. $n \mathrm{l} /$ ThemaResultaat.aspx? subpubID =2232\&themaID = 3577\&indicatorID $=7722$

De verwijzingen staan op:

- Pagina 9 en 13: zie agrimatie.nl (in het blauw);

- Pagina 29 en 31: zie factsheets per provincie (in blauw);

- Pagina 27, 33 en 34: zie provinciale factsheets (in blauw). 


\section{Inhoud}

Erratum bij Rapport 2021-067 i

Addendum bij Rapport 2021-067 ii

Woord vooraf $\quad 5$

Samenvatting $\quad 6$

S.1 Belangrijkste resultaten $\quad 6$

$\begin{array}{lll}\text { S.2 Overige resultaten } & 8\end{array}$

$\begin{array}{ll}\text { S.3 Methodiek } & 9\end{array}$

$\begin{array}{ll}\text { Summary } & 10\end{array}$

$\begin{array}{lll}\text { S.1 Key results } & 10\end{array}$

S.2 Other results $\quad 12$

S.3 Methodology 13

$1 \quad$ Inleiding $r$

1.1 Aanleiding $\quad 14$

1.2 Probleemstelling $\quad 15$

$\begin{array}{lll}1.3 & \text { Doelstelling en deelvragen onderzoek } & 15\end{array}$

1.4 Aanpak en opbouw rapport 16

$2 \quad$ Monitor korte ketens $\quad 18$

$\begin{array}{lll}2.1 & \text { Inleiding } & 18\end{array}$

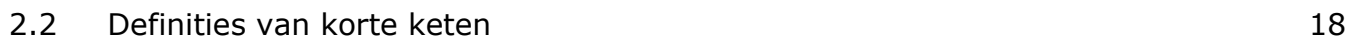

$\begin{array}{ll}2.3 \text { Methodiek } & 20\end{array}$

$3 \quad$ Resultaten monitoring korteketenbedrijven $\quad 24$

3.1 Inleiding $\quad 24$

3.2 Naar bedrijfstype $\quad 24$

$\begin{array}{lll}3.3 & \text { Ontwikkeling 2017-2020 } & 25\end{array}$

$\begin{array}{lll}3.4 & \text { Kenmerken korteketenbedrijven } & 28\end{array}$

$\begin{array}{lll}3.5 & \text { Ruimtelijke verdeling } & 30\end{array}$

3.6 Omzet korte keten $\quad 32$

3.6.1 Aandeel omzet korte keten in de bedrijfsomzet $\quad 32$

3.6.2 Ruimtelijke verdeling omzetdichtheid 33

3.6.3 Totale omzet via korte ketens $\quad 34$

4 Suggesties voor stimulering korte ketens 36

$4.1 \quad$ Inleiding $\quad 36$

4.2 Aandacht voor (meervoudige) waarde creatie 36

4.3 Logistiek en organisatie $\quad 36$

$\begin{array}{lll}4.4 & \text { Regelgeving en hoge kosten } & 37\end{array}$

$\begin{array}{lll}4.5 & \text { Kennisontwikkeling } & 37\end{array}$

4.6 Stimuleren van de vraag 38

$\begin{array}{lll}4.7 & \text { Gezamenlijke verantwoordelijkheid } & 38\end{array}$

$5 \quad$ Slotbeschouwing $\quad 40$

$\begin{array}{ll}\text { Literatuur en websites } & 43\end{array}$

$\begin{array}{lll}\text { Bijlage } 1 & \text { Begrippenlijst } & 44\end{array}$

$\begin{array}{lll}\text { Bijlage } 2 & \text { Typering bedrijven } & 46\end{array}$

$\begin{array}{lll}\text { Bijlage } 3 & \text { Detaillering resultaten } & 47\end{array}$ 



\section{Woord vooraf}

Afzet van agrarische producten via korte ketens wordt in toenemende mate door beleid en markt gezien als een middel om te komen tot nieuwe verdienmodellen voor agrarische ondernemers en tot versterking van de verbinding tussen de producerende ondernemers en burgers. Ook kan het een goede bijdrage leveren aan het proces naar meer kringlooplandbouw en versterking van de economie van regio's. De in dit rapport gepresenteerde nulmeting geeft inzicht in de positie van korte ketens in 2020 , en is een basis om ontwikkelingen rond korte ketens in komende jaren zichtbaar te maken in nieuwe metingen. In dit rapport wordt op nationaal niveau inzicht gegeven in aantallen korte keten bedrijven, kenmerken van deze bedrijven en een schatting van de opbrengsten op agrarische bedrijven via afzet van producten via korte ketens. Ook wordt in dit rapport in hoofdlijnen ingegaan op korte ketens in de provincies, met een samenvattend overzicht van aandachtspunten voor verdere stimulering van korte ketens. Dit laatste als output van provinciale sessies. Een uitgebreidere beschrijving van de situatie per provincie is te vinden in een aparte factsheet per provincie. Een woord van dank gaat uit naar de deelnemers in de provinciale sessies en naar de begeleidingscommissie van dit onderzoek.

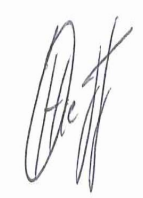

Ir. O. (Olaf) Hietbrink

Business Unit Manager Wageningen Economic Research

Wageningen University \& Research 


\section{Samenvatting}

\section{S.1 Belangrijkste resultaten}

\section{Aantallen korteketenbedrijven}

In 2020 zijn er in Nederland 7.234 primaire agrarische bedrijven die (een deel van de) door hen geproduceerde of bewerkte voedsel- en sierteeltproducten afzetten via een korte keten. In dit onderzoek wordt een korte keten gedefinieerd als afzet rechtstreeks of via 1 tussenschakel aan de consument (zie S.3 Methodiek). De bedrijven met afzet via een korte keten (hierna 'korteketenbedrijven') vertegenwoordigen 13,7\% van alle bedrijven. Van de korteketenbedrijven verkopen 3.401 bedrijven uitsluitend rechtstreeks aan de consument, 2.107 bedrijven uitsluitend via 1 tussenschakel, en 1.726 zowel rechtstreeks als via 1 tussenschakel. De bedrijfstypen met het hoogste aantal korteketenbedrijven zijn overig tuinbouw, melkveehouderij, en overig graasdierhouderij. Het aandeel korteketenbedrijven in het totaal aantal bedrijven is het hoogst bij de bedrijfstypen blijvende teelt, glastuinbouw en de groep overig tuinbouw (met name boomkwekerij en opengrondsgroente). De aanwezigheid van relatief veel korteketenbedrijven in een bedrijfstype heeft sterk te maken met het feit dat er geen of nauwelijks bewerking nodig is voordat het product aan de eindconsument kan worden verkocht. Dit geldt in sterke mate voor eieren en fruit, maar ook voor bijvoorbeeld meerdere groenten, planten en bloemen.

\section{Ontwikkeling 2017-2020}

Het aantal korteketenbedrijven is de laatste jaren met meer dan een kwart gegroeid: van 5.735 bedrijven in 2017 naar 7.234 bedrijven in 2020 (situatie per 1 april 2020). Het aandeel is nog sterker gestegen: van 10,5\% in 2017 naar 13,7\% in 2020. In Drenthe, Limburg, Noord-Holland en Zuid-Holland is dit aandeel het meest toegenomen. Kijken we naar het aandeel per bedrijfstype dan zijn de sterkste groeiers de glastuinbouw en de overig tuinbouw.

De ontwikkeling van het aantal korteketenbedrijven heeft vooral plaatsgevonden op de qua economische omvang (in standaardverdiencapaciteit) zeer kleine bedrijven: van ruim 1.600 korteketenbedrijven in 2017, naar bijna 2.300 bedrijven in 2020. Binnen de groepen kleine bedrijven en zeer grote bedrijven was de toename met een derde eveneens groot.

\section{Kenmerken van korteketenbedrijven}

Van de 52.695 bedrijven die de Landbouwtelling vertegenwoordigt, heeft ruim een derde een economische omvang die als zeer klein kan worden bestempeld. Ruim $12 \%$ van deze bedrijven is een korteketenbedrijf. Het aandeel korteketenbedrijven ligt het hoogst voor de groep zeer grote bedrijven (bijna 20\%).

Kijken we naar de leeftijd van het bedrijfshoofd, dan bevinden zich in de groep jonger dan 40 jaar procentueel gezien (17\%) de meeste korteketenbedrijven. Maar ook op bedrijven met een bedrijfshoofd vanaf 65 jaar zijn er bedrijven met rechtstreekse afzet of via 1 tussenschakel (10\% van de bedrijven).

Op bedrijven (met een bedrijfshoofd vanaf 51 jaar) met een potentiële bedrijfsopvolger ligt dit percentage met $13 \%$ iets beneden het nationale gemiddelde, en slechts iets hoger dan voor de groep oudere bedrijfshoofden zonder opvolger.

$\mathrm{Er}$ is een sterke relatie tussen afzet van producten via korte ketens en multifunctionele activiteiten. Zo vindt op bijna 30\% van de bedrijven met agrotoerisme en op meer dan een derde van de zorgboerderijen ook afzet van eigen geproduceerde producten via een korte keten plaats. De bedrijven met educatieactiviteiten scoren nog hoger (43\%). Het is niet verrassend dat bedrijven die zelf producten verwerken (zoals zelfkazers), deze producten veelal (88\%) direct aan de consument of via 1 tussenschakel verkopen. 
Het aandeel korte ketens in de biologische landbouw (39\%) ligt in procentpunten gezien driemaal hoger dan voor de bedrijven met gangbare productiesystemen (13\%). Het percentage biologische bedrijven met afzet via een korte keten in de provincies loopt uiteen van $23 \%$ in Flevoland tot $49 \%$ in Noord-Brabant.

\section{Ruimtelijke verdeling}

Absoluut gezien bevinden de meeste korteketenbedrijven zich in de provincie Noord-Brabant, gevolgd door Gelderland en Zuid-Holland. In de Noordelijke provincies en in midden-Nederland zijn de aantallen bedrijven met afzet via een korte keten het laagst. Procentueel gezien scoort Limburg het hoogst met een aandeel van $20 \%$ van alle agrarische bedrijven die afzet via een korte keten, gevolgd door Noord- en Zuid-Holland (19\%). De provincies Groningen, Friesland en Overijssel zitten qua aandeel nog onder de $10 \%$.

In de drie provincies met de meeste korte ketens, zijn veel van de onderscheiden hoofdbedrijfstypen goed vertegenwoordigd. Dit geldt vooral voor de provincie Gelderland. In meerdere provincies zien we daarentegen een sterke overheersing van 2 à 3 bedrijfstypen binnen het aantal korteketenbedrijven. Zo omvatten de melkveehouderij en overige graasdierhouderij in de provincies Friesland, Overijssel en Utrecht meer dan de helft van de korteketenbedrijven. In Zeeland en Flevoland (en in mindere mate Groningen) bevindt het grootste aantal korteketenbedrijven zich in de akkerbouw.

In Noord-Brabant en ook in Noord-Holland en Limburg bevinden zich relatief veel korteketenbedrijven in de groep Overig tuinbouw. De korteketenbedrijven in de blijvende teelt (vooral fruitteelt en/of wijngaarden) bevinden zich vooral in de provincies Gelderland, Zeeland en Limburg.

Naast de aanwezigheid van welk bedrijfstype, en dan vooral producten met geen of weinig bewerking vooraf aan consumeren, speelt aan de vraagkant bevolkingsdichtheid, recreatie en horeca een rol bij de mate van afzet via korte ketens.

\section{Opbrengsten via korte ketens}

Het aandeel in de omzet loopt sterk uiteen. Op 45\% van de korteketenbedrijven bedraagt de gerealiseerde bedrijfsopbrengst minder dan $10 \%$ van de totale bedrijfsopbrengst. Hier staat tegenover dat op meer dan een kwart van de bedrijven het bedrijfshoofd aangeeft dat dit meer dan de helft is.

De totale opbrengsten door verkoop via korte ketens op agrarische bedrijven gerepresenteerd in de Landbouwtelling wordt geschat op minimaal 1,359 miljard euro over de periode april 2019 t/m maart 2020.

De hoogste korte keten omzet wordt gerealiseerd in Zuid-Holland (356 miljoen euro), op afstand gevolgd door Noord-Brabant (212 miljoen) en Noord-Holland (177 miljoen). In Zuid-Holland zorgt de glastuinbouw voor liefst $80 \%$ van de provinciale korte keten omzet. De aanwezigheid van bedrijfstypen is een belangrijke factor (met name producten met weinig of geen bewerking) in de hoogte van de omzet per provincie, naast de omvang van de vraag door inwoners en toeristen (en als afgeleide hiervan de horeca). Ook logistieke mogelijkheden zijn relevant waarbij samenwerking in toenemende mate essentieel is/wordt.

Ook op nationaal niveau levert de glastuinbouw met bijna 600 miljoen euro verreweg de grootste bijdrage aan de omzet (44\%). Dit komt mede doordat relatief veel bedrijven in de reguliere markt afzetten via 1 tussenschakel. Ook de hoge gemiddelde bedrijfsopbrengsten in de glastuinbouw spelen mee. Op grote afstand volgen de melkveehouderij (195 miljoen) en de groep overig tuinbouw (210 miljoen), waaronder opengrondgroentebedrijven, boomkwekerijen, champignonbedrijven en bloembollenbedrijven. Kijken we ook naar het aantal bedrijven binnen een bedrijfstype, dan is de omzet relatief hoog in de leghennenhouderij en de fruitteelt.

De regionale omzetdichtheid is het hoogst in de specifieke glastuinbouwgebieden in Nederland (figuur S.1). De glastuinbouwbedrijven staan relatief dicht op elkaar, hebben relatief weinig grondoppervlakte, en gemiddeld (zeer) hoge bedrijfsopbrengsten. Met name in de regio's met veel (grote) grondgebonden bedrijven is de omzetdichtheid per $\mathrm{km}^{2}$ lager. Ook is de bevolkingsdichtheid in 
deze regio's relatief laag. De overheersing van grondgebonden landbouw zien we terug in de Noordelijke provincies, Zeeland en in Flevoland. Ook in Noord-Holland, Utrecht, Overijssel zijn regio's met veel grondgebonden bedrijven.

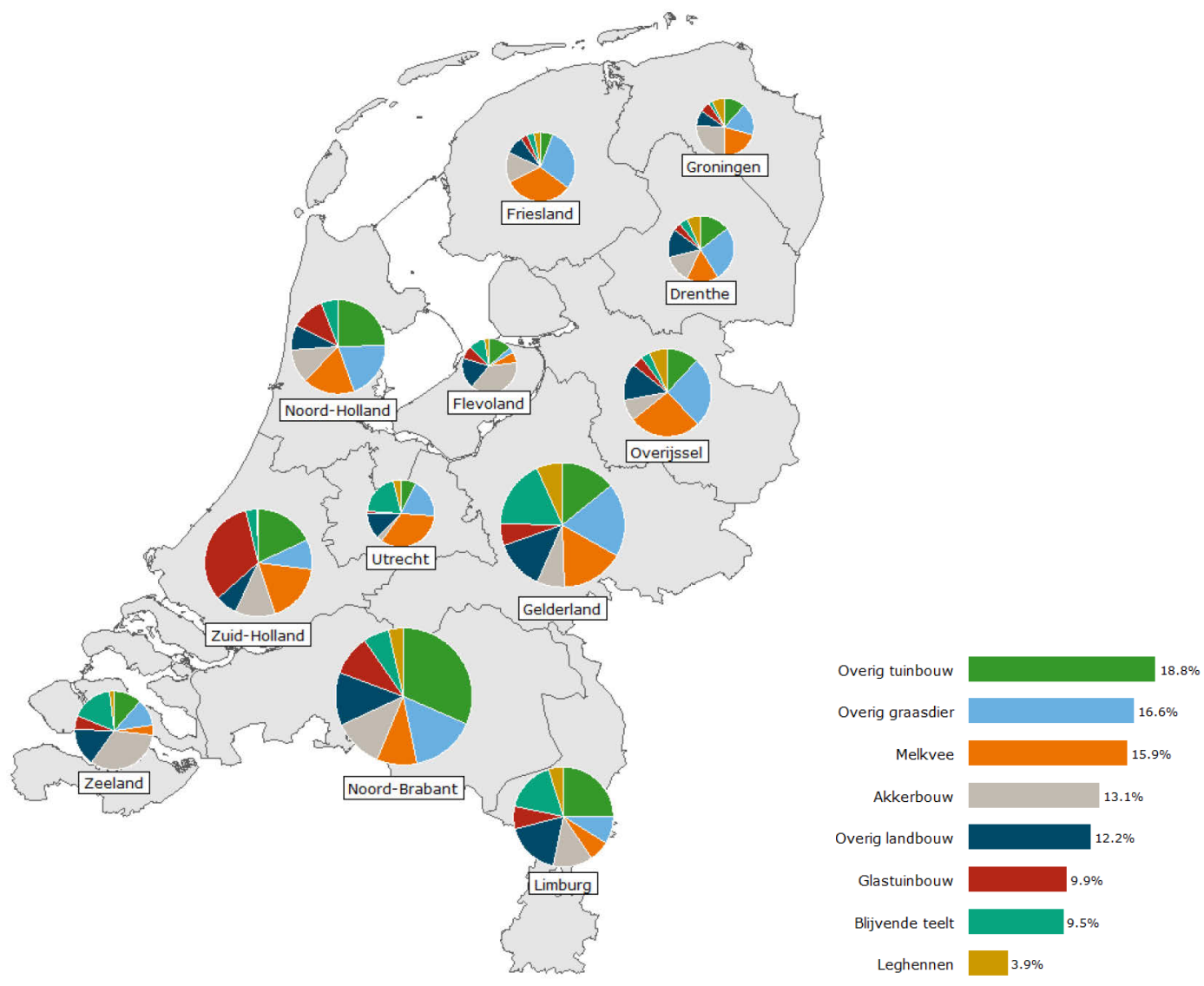

Figuur S.1 Agrarische bedrijven met afzet via korte keten per provincie, ingedeeld naar aandeel bedrijfstype per provincie a), b), 2020

a) De omvang van een cirkel heeft een directe relatie met het aantal korteketenbedrijven;

b) percentage = aandeel bedrijfstype in totaal aantal korteketenbedrijven per provincie.

Bron: Landbouwtelling.

\section{S.2 Overige resultaten}

In provinciale onlinesessies hebben genodigde personen naast een reflectie op de gepresenteerde cijfers en ontwikkelingen met betrekking tot korte ketens in hun provincie ook huidige belemmeringen en mogelijke handelingsperspectieven benoemd. In deze sessies kwam een aantal aandachtspunten naar voren:

- Meervoudige waardecreatie biedt kansen waar de korte keten onderdeel van kan zijn. Ondernemers zouden meer kennis van de afzetmarkt (wie, waar, welke eisen) kunnen vergaren.

- Logistiek is nog steeds een grote uitdaging voor veel korte keten initiatieven. Vooral de wijze waarop dit binnen de korte keten logisch en efficiënt georganiseerd kan worden.

- De toegankelijkheid van subsidies zou beter kunnen. Procedures zijn vaak omslachtig en de boer vindt niet altijd de weg naar subsidies.

- Kennisontwikkeling is van belang om de gehele korte keten (van producent tot consument) verder te ontwikkelen. Er worden rollen gezien voor onderwijs, overheden, banken, kennisinstellingen, ketenpartijen, burgerinitiatieven en uiteraard de ondernemer zelf.

- Gezamenlijke verantwoordelijkheid in de korte keten is een punt dat veel werd benoemd in de Provinciale sessies. Zowel boeren, overheden en ketenpartijen moeten verantwoordelijkheid nemen om gezamenlijk succes te hebben. Samenwerking is daarbij uiterst belangrijk. 
- Hoewel dit onderzoek gericht is op de productiekant van de korte keten wordt ook nadrukkelijk de verdere ontwikkeling van de marktkant (pull) benoemd als belangrijk aandachtspunt om korte ketens verder te ontwikkelen.

Voor een uitgebreider beeld van de korteketenbedrijven in de agrarische sector voor de provincies, wordt verwezen naar de factsheets per provincie (agrimatie.nl).

\section{S.3 Methodiek}

De kernvragen in deze monitor van korte ketens zijn inzicht verkrijgen in het aantal primaire agrarische bedrijven in Nederland dat voedsel- of sierteeltproducten rechtstreeks of via 1 tussenschakel afzet aan consumenten, de kenmerken en locatie van deze zogenaamde korteketenbedrijven, en het verkrijgen van inzicht in de omzet die gepaard gaat met afzet via een korte keten.

Er zijn meerdere definities van het begrip korte keten in de land- en tuinbouw. Dit loopt uiteen van meer beschrijvende definities met daarin economische, sociale en lokale kenmerken, tot een meer meetbare definitie waarin afzet van voedings- en sierteeltproducten aan de consument rechtstreeks of via 1 tussenschakel wordt meegenomen. Laatstgenoemde definitie is ook gehanteerd in een vraag naar korte ketens in de Landbouwtelling (RVO). Het voordeel van deze database is dat (waarschijnlijk op enkele procentpunten na) de Nederlandse primaire landbouwproductie wordt gerepresenteerd. Door de provincies, het ministerie LNV en de Taskforce Korte Keten (TKK) is de korte keten gedefinieerd als een toeleveringsketen met een beperkt aantal marktdeelnemers die zich inzetten voor samenwerking, lokale economische ontwikkeling en nauwe geografische en sociale betrekkingen tussen voedselproducenten, -verwerkers en consumenten.

Door de beschikbaarheid van data is deze monitor korte ketens gebaseerd op de Landbouwtelling 2020, die loopt van 1 april 2019 tot en met 31 maart 2020. Dit is een periode waarin de invloed van COVID-19 op verkoop via korte ketens nauwelijks aanwezig is geweest. Voor de ontwikkeling van het aantal korteketenbedrijven is een vergelijking gemaakt met gegevens uit de Landbouwtelling 2017. Deze ontwikkeling is in beeld gebracht voor provincies, hoofdbedrijfstypen en de economische omvang van bedrijven. Ook is op basis van de Landbouwtelling 2020 inzicht gegeven hoe groot het aandeel bedrijfsopbrengsten gerealiseerd via korte ketens is in de totale bedrijfsopbrengsten. Op basis van deze aandelen is een onderbouwde schatting gemaakt van de totale bedrijfsopbrengsten op een bedrijf en een indicatie gegeven van de omzet korte ketens per provincie en hoofdbedrijfstype.

De gepresenteerde cijfers over korte ketens op basis van de Landbouwtelling 2020 kunnen naar verwachting een beperkte onderschatting geven. In toenemende mate splitsen ondernemers hun bedrijven (als gevolg van bijvoorbeeld wetgeving, fiscale voordelen, of risicospreiding) in meerdere zelfstandige bedrijven met vaak een eigen rechtsvorm en boekhouding. Dit komt ook voor bij agrarische bedrijven met multifunctionele activiteiten, waaronder ook rechtstreekse verkoop. Eveneens representeert de Landbouwtelling niet de visserijbedrijven. Ook visproducten kunnen via een korte keten bij de consument komen. Dit is niet meegenomen in dit onderzoek. De resultaten op basis van de Landbouwtelling zijn eveneens per provincie gepresenteerd in een sessie met groepen betrokkenen bij korte ketens in de betreffende provincie. Daarbij zijn feedback en aanvullingen op de gepresenteerde resultaten ontvangen. Ook zijn in deze provinciale sessies inzichten verkregen in aanwezige knelpunten bij de verdere ontwikkeling van afzet via korte ketens, uitmondend in aanbevelingen richting beleid en markt. In deze publicatie van de monitor korte ketens zijn de belangrijkste knelpunten en aanbevelingen samengevat weergegeven. In de factsheet voor iedere provincie worden de belangrijkste verkregen inzichten uit de sessie kort beschreven. Ook worden in deze factsheets de belangrijkste resultaten uit de monitor korte ketens per provincie gepresenteerd en toegelicht. 


\section{Summary}

\section{S.1 Key results}

\section{Number of short-chain companies}

In 2020 there were 7234 primary agricultural companies in the Netherlands that sold part of or all of their produced or processed food and horticultural products via a short chain. In this study, a short chain is defined as selling directly or via a single intermediary to the consumer (see 5.3 Methodology). The companies that sold via a short chain (short-chain companies) represent $13.7 \%$ of all companies. Among short-chain companies, 3401 companies sell directly to the consumer, 2107 companies sell only via a single intermediary, and 1726 sell both directly and via a single intermediary. The company types with most short-chain companies are 'other horticulture', 'dairy farming', and 'other livestock farming'. The proportion of short-chain companies is highest in the company types 'permanent crop farming', 'greenhouse farming', and 'other horticulture' (in particular 'arboriculture' and 'open soil vegetable production'). The relatively high number of short-chain companies within a specific company type is strongly related to little or no processing being required before the product can be sold to the end consumer. This is especially the case for eggs and fruit, but also for many vegetables, plants and flowers.

\section{Developments from 2017 to 2020}

In the last few years, the number of short-chain companies increased by more than $25 \%$ : from 5735 companies in 2017 to 7234 companies in 2020 (per 1 April 2020). Their percentage increased even more: from $10.5 \%$ in 2017 to $13.7 \%$ in 2020 . This percentage increased most in Drenthe, Limburg, North Holland and South Holland. Looking at percentage per company type, the strongest increase took place in 'greenhouse farming' and 'other horticulture'.

The increase in number of short-chain companies mostly occurred among companies with a very small economic scope (in standard earning power): from more than 1600 short-chain companies in 2017 to nearly 2300 companies in 2020. A strong increase was also observed among small and very large companies.

\section{Features of short-chain companies}

Of the 52,695 companies listed in the Agricultural Census, more than one third has an economic scope that can be described as very small. More than $12 \%$ of these companies are short-chain companies. The percentage of short-chain companies is highest among very large companies (nearly $20 \%$ ).

Looking at the age of the company holder, most short-chain companies (17\%) are owned by farmers aged under 40. However, companies with a company holder aged 65 and older also include companies selling their products directly or via a single intermediary ( $10 \%$ of companies).

Among companies (with a company holder aged 51 and older) with a potential successor this percentage is $13 \%$, which is a little lower than the national average, and only a little higher than in the group with older company holders without a successor.

There is a strong link between selling products via a short chain and multifunctional activities. For example, nearly $30 \%$ of short-chain companies also engage in agritourism and more than one third of care farms also sell their own products via a short chain. Companies that offer educational activities score even higher (43\%). It is not surprising that companies that process their products themselves (for example cheesemakers) usually sell these products directly or via a single intermediary (88\%).

The percentage of short chains in organic agriculture (39\%) is three times higher than among companies with regular production systems (13\%). The percentage of organic companies that sell via a short chain in the various provinces varies from $23 \%$ in Flevoland to $49 \%$ in North Brabant. 


\section{Geographical distribution}

In absolute terms, most short-chain companies are located in the province of North Brabant, followed by Gelderland and South Holland. The number of companies that sell via a short chain is lowest In the Northern provinces and Central Netherlands. In terms of percentages, Limburg scores highest with $20 \%$ of all agricultural companies selling via a short chain, followed by North and South Holland (19\%). The provinces of Groningen, Friesland and Overijssel still score only under $10 \%$.

In the three provinces with most short-chain companies, many of the defined company types are well represented. This is particularly true of Gelderland. On the other hand, there are some provinces where short-chain companies are clustered within two or three company types. For example, 'dairy farming' and 'other livestock farming' account for more than half of all short-chain companies in Friesland, Overijssel and Utrecht. In Zeeland and Flevoland (and to a lesser extent in Groningen), most short-chain companies are found in 'arable farming'.

In North Brabant, and also in North Holland and Limburg, most short-chain companies are found in 'other horticulture'. Short-chain companies in 'permanent crops' (especially fruit farming and/or vineyards) are mostly located in Gelderland, Zeeland and Limburg.

In addition to the presence of specific company types, and especially the availability of products with little to no processing prior to consumption, factors on the consumer side that affect sales scope via short chains are population density, recreation and catering.

\section{Revenue from short chains}

The turnover percentage varies greatly: for $45 \%$ of short-chain companies, realised short-chain revenue represents less than $10 \%$ of the total company revenue. On the other hand, for more than $25 \%$ of companies, the company holder indicates that this revenue exceeds $50 \%$.

The total revenue from sales via short chains among the agricultural companies listed in the Agricultural Census is estimated at a minimum of $€ 1359$ billion a year (1 April 2019 to 31 March 2020).

The highest short-chain revenue is realised in South Holland ( $€ 356$ million), followed at some distance by North Brabant ( $€ 212$ million) and North Holland ( $€ 177$ million). In South Holland, 'greenhouse farming' accounts for no less than $80 \%$ of the province's short-chain revenue. The presence of specific company types is an important factor (in particular companies that sell products with little to no processing) in revenue level per province, in addition to the level of demand among inhabitants and tourists (and relatedly the availability of catering). Logistical possibilities also play a role, with collaboration becoming increasingly essential.

At national level too, 'greenhouse farming' makes by far the greatest contribution to revenues, with nearly $€ 600$ million (44\%). This is partially due to the fact that relatively many companies in the regular market sell via a single intermediary. Another factor that plays a role is high average company revenues in 'greenhouse farming'. This is followed at a great distance by dairy farming (a little under $€ 200$ million) and 'other horticulture' ( $€ 210$ million), including 'open soil vegetable production', 'arboriculture', 'mushroom farms' and 'flower bulb companies'. If we look at the number of companies within a company type, revenue is highest in poultry and fruit farming.

The regional revenue density is highest in traditional greenhouse farming areas in the Netherlands (figure S.1). Greenhouse companies are located relatively close together, have relatively little land, and relatively high to very high company revenues. In particular in regions with many land-bound farms, revenue density per $\mathrm{km}^{2}$ is lower. Population density in these regions is also relatively low. The dominance of land-bound farming is a factor in the Northern provinces, Zeeland and Flevoland. North Holland, Utrecht and Overijssel are also regions with a high number of land-bound companies. 

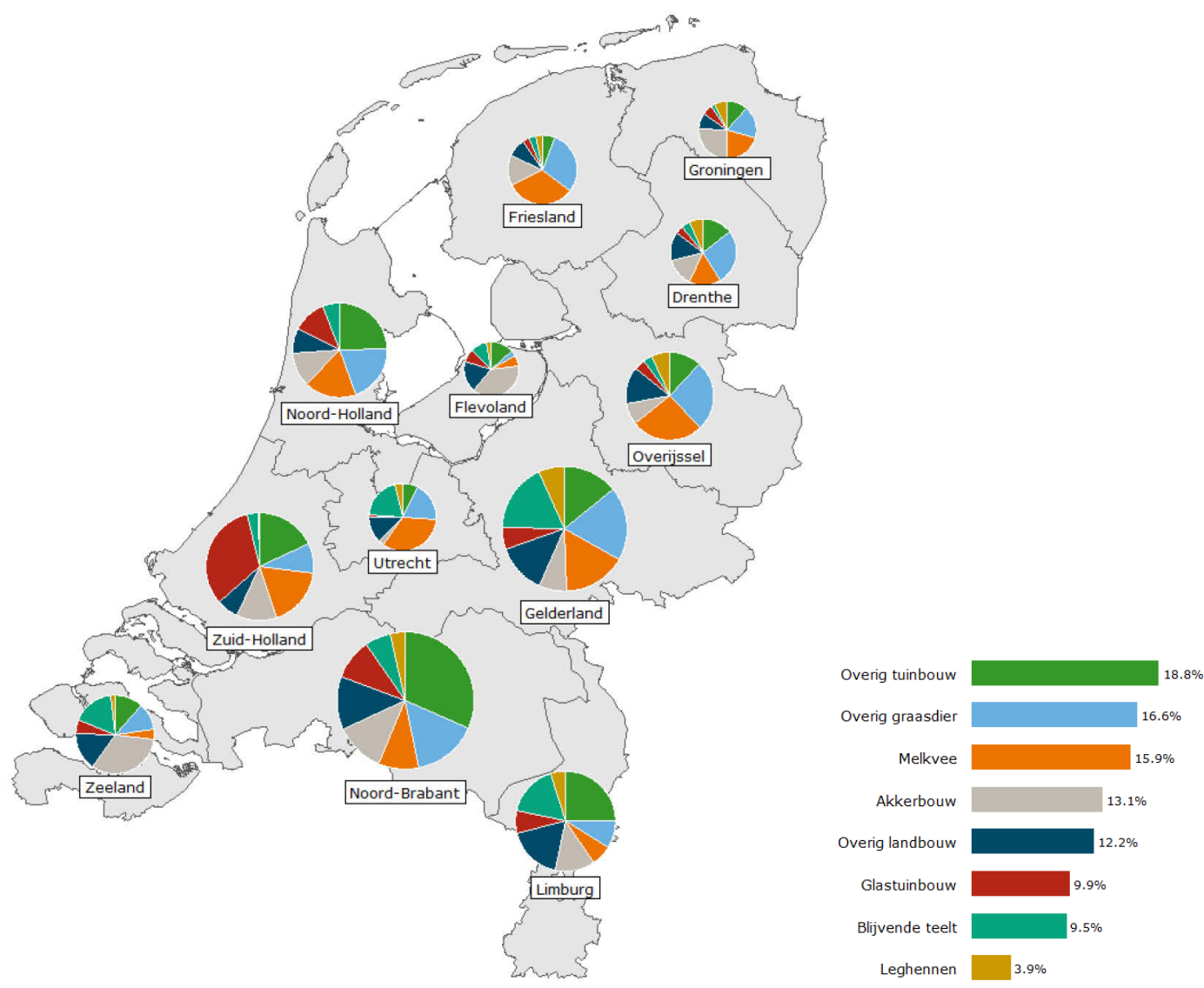

Figure S.1 Agricultural farms with short-chain sales per province, classified according to share in business type per province a), b)

a) The size of a circle has a direct relation with the number of short-chain farms; b) percentage= share of business type in total number of short-chain farms per province.

Source: Landbouwtelling.

\section{S.2 Other results}

In provincial online sessions, in addition to reflecting on the presented figures and developments with respect to short chains in their province, participants were also invited to list current obstacles and potential action perspectives. From these sessions, a number of points of focus emerged:

- Multiple value creation offers opportunities that may include a short chain. Entrepreneurs could gather more knowledge of the target market (who, where, what are the requirements).

- Logistics is still a big challenge for many short-chain companies. In particular, companies struggle with how to organise a short chain logically and efficiently.

- Access to subsidies could be improved. Procedures are often cumbersome and company holders do not always find their way to the subsidies.

- Knowledge development is important to further develop the entire short chain (from producer to consumer). The following parties can play a role in this respect: educational institutions, governments, banks, knowledge institutions, short-chain parties, citizen initiatives and of course the entrepreneurs themselves.

- Joint responsibility in the short chain was often mentioned in the provincial sessions. Farmers, governments and short-chain parties should take responsibility for joint success. Collaboration is crucial in this context.

- Although this study focuses on the production side of the short chain, further development on the market side (pull) was expressly mentioned as an important point of focus in further developing short chains. 
For a more extensive perspective on short-chain companies in the agricultural sector for the various provinces, we refer the reader to the factsheets per province (agrimatie.nl).

\section{S.3 Methodology}

The central objectives of this short-chain monitor were to gain insight in the number of primary agricultural companies in the Netherlands that sell food or horticultural products directly or via a single intermediary to the consumer, define the features and geographical location of these short-chain companies, and gain insight in revenues from short-chain sales.

There are a number of definitions of 'short chain' in agriculture and horticulture, varying from more descriptive definitions based on economic, social and local features to more measurable definitions that include revenues from selling food and horticulture products directly or via a single intermediary to the consumer. We used the latter definition to investigate short chains in the Agricultural Census (RVO). The advantage of this database is that it represents all Dutch primary agricultural production (probably with a margin of a few percent). The provinces, the Ministry of Agriculture, Nature and Food Quality and the Short-Chain Taskforce (Taskforce Korte Keten, TKK) define the short chain as a supply chain with a limited number of market operators committed to collaboration, local economic development, and close geographical and social relations between food producers, food processors and consumers.

Using the available data, this short-chain monitor is based on the 2020 Agricultural Census, which runs from 1 April 2019 to 31 March 2020. This is a period during which the impact of COVID-19 on short-chain sales was scarcely noticeable. To assess the development in the number of short-chain companies, a comparison was made with data from the 2017 Agricultural Census. This development was mapped for provinces, main company types, and economic scope of the companies. The 2020 Agricultural Census was also used to gain insight in the percentage of company revenue realised through short chains as compared to total company revenue. Based on these percentages, a substantiated estimate was made of the total revenue of a company and an indication was given of the short-chain revenue per province and company type.

The short-chain data presented here and based on the 2020 Agricultural Census may possibly involve a slight underestimation. Entrepreneurs are increasingly splitting their companies (for reasons of legislation, tax advantages or risk spreading) into a number of independent companies, often with their own legal form and accountancy. This also happens in agricultural companies with multifunctional activities, including direct product sales. Furthermore, the Agricultural Census does not include fishing companies. Fish products can also be sold to consumers via a short chain. This is not included in this study. The results based on the Agricultural Census were also presented in a session with short-chain stakeholders from the relevant province. This allowed us to gather feedback and additions to the presented results. The provincial sessions also helped us gain insight into the current obstacles to further development of short-chain sales, leading to some policy and market recommendations. This short-chain monitor lists the most important obstacles and recommendations. The province factsheets briefly describe the most important insights from the relevant sessions. These factsheets also present and explain the most important results of the short-chain monitor per province. 


\section{$1 \quad$ Inleiding}

\section{$1.1 \quad$ Aanleiding}

Het ministerie van Landbouw, Natuur en Voedselkwaliteit (LNV) heeft Wageningen Economic Research de vraag gesteld een landelijke nulmeting op te stellen die kwantitatief inzicht biedt in de situatie en de ontwikkeling van het aantal agrarische bedrijven dat een deel van de productie afzet via een korte keten.

In de visie Landbouw, Natuur en Voedsel; waardevol en verbonden (2018) is de erkenning van waarde van voedsel en het versterken van de relatie tussen boer en burger een van de

5 speerpuntonderwerpen. De korte keten is voor het ministerie van LNV een belangrijk aandachtspunt bij vooral de volgende beleidsthema's:

- LNV stelt kringlooplandbouw centraal in de transitie naar een duurzame landbouw. Het ziet korte ketens als een van de middelen om kringlooplandbouw te bevorderen.

- LNV wil de verbinding tussen boeren, natuurbeschermers en burgers versterken om elkaar beter te leren begrijpen en samen te werken naar een degelijk en duurzaam voedselsysteem. Het verkleinen van de afstand tussen primaire producenten en burgers is ook van belang om onder meer de waardering van voedsel te vergroten. Dit als antwoord op de initiatiefnota van het lid Dik-Faber getiteld Verbinding boer(in)-burger.

- LNV hecht veel waarde aan de ontwikkeling van nieuwe verdienmodellen in de agrarische sector. In hoeverre leiden nieuwe initiatieven rond korte ketens tot positieve gevolgen voor de inkomens van boeren en tuinders?

Ook bij provincies ${ }^{1}$ heeft het thema korte ketens volop aandacht in het beleid. Zo hebben meerdere provincies projecten rond stimulering korte ketens opgenomen in de lopende plattelandsontwikkelingsprogramma's (POP3). Ook wordt stimulering van korte ketens in toenemende mate in de provinciale landbouwagenda's opgenomen, of zijn aandachtspunt voor de nieuwe landbouwagenda.

In opdracht van de provincie Gelderland is in 2019 op basis van de Landbouwtelling 2017 een analyse gemaakt van de omvang en dynamiek in de provinciale korteketensector (Van der Schans en Van Wonderen, 2019). De resultaten zijn besproken met vertegenwoordigers van diverse provincies, bij elkaar gekomen in het kader van de City Deal Voedsel op de stedelijke agenda. Er blijkt ook bij andere provincies behoefte aan een kwantitatief beeld van de omvang en verspreiding van korte ketens op hun grondgebied.

Op 5 oktober 2020 was de bijeenkomst Nationale Handelsmissie korte ketens, georganiseerd door het ministerie van LNV en de provincies, in samenwerking met de Taskforce Korte Keten. In deze Handelsmissie werd gezocht naar inspirerende voorbeelden in de korte keten. Deze bezoeken stonden in het teken van het ondersteunen van pioniers, nieuwe kansen ontdekken en kijken hoe de band tussen boeren en buurt kan worden versterkt. Twee belangrijke uitkomsten waren: De Nederlandse provincies, het ministerie van LNV en de Taskforce Korte Keten gaan intensief samenwerken om de ontwikkeling van de korte keten te versnellen. Eveneens is de cateringdeal 'Eten uit de Korte Keten' ondertekend. ${ }^{2}$

\footnotetext{
1 Een voorbeeld is Gelderland. De provincie neemt een actieve rol in het voedselbeleid en ondersteunt - al jaren - de ontwikkeling van korte ketens en de transitie in de landbouw. In het Coalitieakkoord van de Provincie Gelderland wordt de afzet van lokale producten als beleidsspeerpunt genoemd, voor een levensvatbaar voortbestaan van de participerende boerenbedrijven en het in stand houden van de belangrijke bijdragen aan veilig, gezond en duurzaam voedsel voor haar inwoners en de regionale economie. Gelderland kent talrijke voedselinitiatieven van primaire ondernemers, maar het is nog niet duidelijk waar deze lokale producten terechtkomen.

2 Bron: https://taskforcekorteketen.nl/2020/
} 
In september 2020 vond de kick-off plaats van de Rabo Food Forward korte keten-track. Rabo Food Forward (het innovatieprogramma voor voedselondernemers van Rabobank), de Taskforce Korte Keten en Food Hub hebben de handen ineen geslagen voor een programma voor iedereen die een rol speelt in de korte keten: van producenten, consumenten, retailers en distributeurs tot beleidsmakers, webdevelopers en data-analisten. ${ }^{3}$

Dit zijn voorbeelden van ontwikkelingen in zowel beleid als markt om korte ketens te stimuleren.

\subsection{Probleemstelling}

De rijksoverheid en diverse provincies zetten via allerlei initiatieven in op het thema korte voorzieningsketens (regionale voedselvoorziening), zowel in het kader van een vitaal platteland als ten behoeve van de vitaliteit van steden en regio's. Met de toenemende beleidsinzet neemt ook de behoefte toe aan inzicht. In welke sectoren en in welke regio's slaan korte ketens aan, waar liggen knelpunten en daarmee aandachtspunten voor beleid en markt? Wat is de dynamiek door de jaren heen, neemt het aandeel van de omzet via korte ketens in de totale omzet van agrariërs toe? Is er een verband tussen deelname in de korte keten en economische prestaties?

\section{Doelgroep}

De doelgroep van dit onderzoek zijn beleidsmakers bij het Rijk en bij de provincies, en ook regio's/gemeenten in Nederland. Het gaat vooral om beleidsmakers plattelandsontwikkeling, economische ontwikkeling van de landbouw, en ruimtelijke ordening en stad-plattelandrelaties. Daarnaast is het onderzoek van belang voor de sectororganisaties in de agrarische sector, zoals ten aanzien van inzet van belangenbehartiging ten behoeve van korte ketens. Waar liggen de aandachtspunten voor verdere stimulering (ontwikkeling) van korte ketens, waar is ondersteuning nodig? Levert verkorting van ketens een bijdrage aan verbetering van de inkomenspositie en daarmee het perspectief van bedrijven? Ook voor het dienstverlenende bedrijfsleven zijn de onderzoeksresultaten van belang (in verband met het al dan niet aanbieden van specifiek op de korte keten gerichte diensten).

\subsection{Doelstelling en deelvragen onderzoek}

Doelstelling van dit onderzoek is het opzetten van een monitor korte ketens en het uitvoeren van een nulmeting. De nulmeting is gebaseerd op data uit de Landbouwtelling 2020 (tot 1 april 2020) en omvat een terugblik op de ontwikkeling tussen 2017 en 2020. De monitor 2020 kan als benchmark worden gebruikt voor een terugkerende monitor korte ketens.

Het onderzoek bevat de volgende onderdelen:

- Het opzetten van een monitor korte ketens. Belangrijk aandachtspunten hierbij zijn de definitie en de te gebruiken bronnen

- Resultaten monitor korte ketens op nationaal niveau

- Resultaten op provinciaal niveau (een verkorte versie van nationaal niveau)

- Aandachtspunten voor verdere stimulering korte ketens (als resultaat van provinciale sessies)

- Conclusies en aanbevelingen

De kernvragen van dit onderzoek luiden:

1. Hoeveel primaire agrarische bedrijven in Nederland zijn een korteketenbedrijf: een bedrijf dat via geen of max 1 tussenschakel producten afzet aan consumenten. Binnen welke bedrijfstypen bevinden zich deze bedrijven? Hoe is de verdeling van deze bedrijven over de provincies en waar zitten deze bedrijven?

\footnotetext{
3 Bron: https://taskforcekorteketen.nl/2020/
} 
2. Wat zijn kenmerken van deze bedrijven qua bedrijfsomvang, leeftijd, productiewijze, continuïteit? In welke mate voeren korteketenbedrijven ook multifunctionele (niet-landbouw)activiteiten uit, zoals agrotoerisme?

3. Hoe groot is het aandeel van omzet verkregen via korte ketens ( 0 of 1 schakel) in de totale omzet van primaire agrarische bedrijven? Is daarmee een schatting te geven van de totale omzet via korte ketens in de agrarische sector?

4. Wat is de ontwikkeling tussen 2017 en 2020 in het aantal korteketenbedrijven, zowel nationaal als op provinciaal niveau?

5. Wat zijn handelingsperspectieven voor beleid en markt om de agrarische afzet via korte ketens te laten groeien?

\subsection{Aanpak en opbouw rapport}

Dit onderzoek heeft de volgende stapsgewijze aanpak:

- bestudering Landbouwtelling als databron voor de opzet en invulling monitor korte ketens agrarische bedrijven. Inzichten in definities, mogelijkheden gebruik data

- opzet en ontwikkeling van het instrument Monitor Korte ketens

- resultaten en analyse op basis van Landbouwtelling 2020 (met waar mogelijk een reflectie ten opzichte van 2017), op nationaal niveau en op provinciaal niveau

- toetsing van voorlopige resultaten per provincie, een sessie met bij korte ketens betrokken personen

- rapportage: op nationaal niveau een rapport met resultaten en gehanteerde definities Monitor 2020; op provinciaal niveau een factsheet met belangrijkste resultaten en beschrijving, te publiceren op Agrimatie.nl

- inzichten in belangrijkste aandachtspunten voor verdere stimulering korte ketens, als resultaat van de gehouden sessies per provincies.

Als eerste is een literatuuronderzoek uitgevoerd naar de definitie van een korte keten in de agrarische sector in Nederland. Bij het begin van het project was al duidelijk dat in de praktijk verschillende definities worden gehanteerd, waarbij theorie en praktijk ook nog eens van elkaar verschillen. In hoofdstuk 2 wordt verder ingegaan op de definitie van een korte keten. Ook komt aan de orde hoeveel korteketenbedrijven via directe verkoop aan de consument (0-schakels) verkopen, of alleen via 1 tussenschakel tussen producent en consument. Ook wordt ingegaan op de databron Landbouwtelling.

De resultaten van de monitor korte ketens worden in hoofdstuk 3 weergegeven. Er wordt inzicht gegeven in het aantal korteketenbedrijven in voor dit onderzoek gekozen hoofdbedrijfstypen (paragraaf 3.2). Hoe deze hoofdtype-indeling zich verhoudt tot de bestaande NSO-typering is terug te vinden in bijlage 2. Daarin wordt ook aangegeven welke (sub)bedrijfstypen vallen onder de gekozen hoofdbedrijfstype indeling. Een beeld van de ontwikkeling in aantallen korteketenbedrijven tussen 2017 en 2020 (per provincie en per bedrijfstype) is terug te vinden in paragraaf 3.3.

Vervolgens wordt ingegaan op meerdere kenmerken van korteketenbedrijven (paragraaf 3.4), zoals de economische omvang van het bedrijf, de leeftijd van het bedrijfshoofd, en de opvolgingssituatie op het bedrijf (bekend voor bedrijfshoofden vanaf 51 jaar). Ook wordt inzicht gegeven in welke mate korteketenbedrijven aan niet-agrarische activiteiten doen (de zogenaamde multifunctionele activiteiten). Deze activiteiten dienen mede ter verbreding van het economisch potentieel van het bedrijf (gezin), en versterking van de boer-burgerverbinding. Vervolgens wordt in paragraaf 3.5 ingegaan op de ruimtelijke verdeling van korteketenbedrijven op provinciaal niveau.

In paragraaf 3.6 komen de opbrengsten uit afzet agrarische producten via een korte keten aan de orde. Hier wordt ingegaan op het aandeel van de opbrengsten door afzet verkoop agrarische producten aan de consument via rechtstreekse verkoop of via 1 tussenliggende schakelde. Het bedrijfshoofd van een korteketenbedrijf heeft hiervan een globale inschatting gemaakt (invullen van 4 percentageklassen: tot $10 \%, 10-30 \%, 30-50 \%,>50 \%$ ) bij het invullen van de Landbouwtelling. Er is vervolgens getracht een zeer globale schatting te maken van de totale opbrengsten in de primaire agrarische sector verkregen door de afzet van land- en tuinbouwproducten via de korte keten. Het hoofdstuk wordt afgesloten met een slotbeschouwing. 
Via provinciale ambtenaren en het onderzoeksteam zijn informanten gevonden met een (sterke) betrokkenheid bij korte ketens in hun provincie. Deze personen, variërend van 8 tot 18 deelnemers per provincie, hebben een reflectie gegeven op de gepresenteerde voorlopige cijfers en ontwikkelingen uit de landbouwtelling, en eigen inzichten hieromtrent. Dit is gedaan in eenmalige sessie (onlinebijeenkomst) zonder verdere voorbereiding van de deelnemers. Ook hebben de genodigde personen huidige belemmeringen en mogelijke kansen benoemd. Van dit laatste gedeelte van de sessie is een samenvattend overzicht gemaakt (hoofdstuk 4).

Als aanvulling op de weergave van de resultaten in dit rapport op nationaal niveau, is voor iedere provincie een aparte factsheet gemaakt met de belangrijkste resultaten voor betreffende provincie ${ }^{4}$ Hierin wordt ingegaan op aantallen (en ontwikkeling 2017-2020) korteketenbedrijven, kenmerken van deze bedrijven, de locatie op COROP-niveau, en een inschatting van de opbrengsten via afzet korte ketens. Deze 12 provinciale factsheets zijn gepubliceerd op Agrimatie.nl.

\section{Uitbraak COVID-19}

Dit onderzoek is uitgevoerd laatste kwartaal 2020 en eerste kwartaal 2021, een periode waarin Nederland te maken had met een COVID-19-uitbraak. De sessies met provincies voor dit onderzoek zijn daarom online uitgevoerd.

Tijdens de lockdown als gevolg van de COVID-19-uitbraak, was er een toenemende interesse voor lokale producten uit de korte keten. Dit heeft zowel bij producenten, consumenten en partijen in de voedingsmiddelenketen (tijdelijk) meer aandacht voor lokale producten opgeleverd. Het is de vraag hoe dit zich verder zal ontwikkelen na COVID-19.

De resultaten van de monitor korte ketens zijn gebaseerd op de Landbouwtelling 2020. Deze telling betreft de resultaten over de periode 1 april 2019 tot en met 31 maart 2020, een periode waarin de invloed van corona nauwelijks aanwezig is geweest.

\footnotetext{
4 De periode van onderzoek bracht met zich mee dat de resultaten in de factsheets gebaseerd zijn op voorlopige cijfers Landbouwtelling 2020. Dit in tegenstelling tot dit nationale rapport, dat gebaseerd is op definitieve cijfers Landbouwtelling 2020.
} 


\section{$2 \quad$ Monitor korte ketens}

\section{$2.1 \quad$ Inleiding}

$\mathrm{Er}$ is afgelopen jaren in Nederland veel discussie zowel in de wetenschap als in de praktijk wat de definitie is van een korte keten in het geval van afzet van voedsel- en sierteeltproducten. Om inzicht te verkrijgen wat er hieromtrent speelt wordt een overzicht gegeven van een aantal toegepaste definities voor korte ketens. Ook wordt hierbij verwezen naar eerdere onderzoeken van Wageningen Economic Research die ingaan op de definitie van korte ketens: Korte ketens in Gelderland (Van der Schans en Van Wonderen, 2019) en Korte keten producten in Nederland; Zijn horeca, catering en supermarkten geïnteresseerd in producten uit de regio? (Tacken et al. 2021).

\subsection{Definities van korte keten}

\section{Europese definitie}

De Europese definitie luidde in eerste aanleg als volgt:

'Korte toeleveringsketen': 'een toeleveringsketen bestaande uit een beperkt aantal marktdeelnemers die streven naar samenwerking, plaatselijke economische ontwikkeling en nauwe geografische en sociale betrekkingen tussen producenten, verwerkers en consumenten' (Verordening (EU) nr. 1305/2013, artikel 2 m).

Later werd de EU-definitie werd verder aangescherpt naar: geen of maximaal één ketenpartij tussen de landbouwpartij en de consument aanwezig is (Commission 2014, Article 11).

\section{Definitie in de Landbouwtelling}

In de Landbouwtelling van RVO, als onderdeel van de Gecombineerde Opgave, is in 2017 en 2020 een vraag opgenomen die zich specifiek richt op de korte keten. Dit om meer zicht te krijgen op de aantallen boeren en tuinders (vissers worden in deze telling niet opgenomen) die een deel van hun producten afzetten via een korte keten. Ook is gevraagd naar een eerste indicatie van de korte keten omzet als percentage van de totale omzet. Een belangrijk punt hierbij is te streven naar een concrete definitie bij de vraagstelling en daardoor voor agrariërs eenvoudiger in te vullen. Dat is een belangrijke reden dat voor de toe te passen definitie in de Landbouwtelling is aangehaakt bij de aangescherpte Europese definitie, die is af te bakenen en daardoor beter meetbaar is dan de meer beschrijvende definitie uit de eerdergenoemde EU-verordening.

In de Landbouwtelling wordt de korte keten afgebakend als: 'Er is sprake van geen of maximaal 1 tussenschakel tussen de producent van agrarische producten en de consument.' Dit houdt in:

- Bij geen tussenschakel is er een rechtstreekse levering aan de consument. Het gaat dan bijvoorbeeld om huisverkoop (inclusief eigen winkel, verkoop langs de weg), op de markt, via een webwinkel, bezorging aan huis, groenteabonnement, boodschappentas of -doos, rechtstreekse verkoop aan consumentencollectief.

- Als er een 'tussenschakel' is, dan kan dat zijn een distributeur, handelaar (markthandel, winkel, webwinkel) of een verwerker (slager, bakker, zuivelaar, horeca, catering).

- Er zijn situaties waarin een dienstverlenend bedrijf niet meetelt als tussenschakel, omdat zij geen eigenaar wordt van het product, maar een dienst verleent die weliswaar nodig is om het product bij de consument te brengen, maar feitelijk als onderaannemer van de boer of de retailer werken. Bijvoorbeeld: vervoerders, loonslachters, bij het verkazen of verzuivelen van melk van een ander en het weer terug leveren van het verwerkte product aan de supermarkt of de boer (in dit geval blijft het een rechtstreekse levering aan de consument door boer, foodservice of retail). Levert een 
zuivelaar of bijvoorbeeld melkfabriek de producten aan de detailhandel, dan valt dit niet onder levering aan consument via één tussenschakel, omdat het eigenaarschap verandert.

Omdat de Landbouwtelling wordt ingevuld door alle boeren en tuinders die als agrariër ingeschreven staan bij de Kamer van Koophandel (zie ook paragraaf 2.3, en bijlage 1) verkrijgen we een totaalbeeld over de hele Nederlandse land- en tuinbouw. Dit kan verder worden ingekleurd naar bijvoorbeeld provincies, bedrijfstypen, leeftijd bedrijfshoofd, omvang bedrijf, etc. Ook maakt toepassing van deze definitie het mogelijk op termijn ook te vergelijken met de ontwikkeling van korte ketens in andere EU-landen.

De verwachting is dat de afzet via korte ketens de komende jaren vaker zal worden onderzocht. Dit biedt mogelijkheden het beeld te actualiseren en de ontwikkeling te volgen.

Een punt van aandacht is dat in de Landbouwtelling de toelichting op de definitie (afbakening) van een korte keten bondig is omschreven. Deze korte toelichting kan leiden tot verschillen in interpretaties tussen ondernemers. Daarbij kan gedacht worden aan: welke afzet valt er nog wel of niet onder rechtstreekse verkoop? In hoeverre is een bepaalde bewerking wel of niet een (volgende) schakel? Hoe wordt een telersvereniging geïnterpreteerd: als een extra schakel of als verlengstuk van de ondernemer?

\section{Andere (meer beschrijvende) definities}

\section{EIP Focus Group 5 korte ketens}

Deze groep richt zich meer op een beschrijvende definitie van korte ketens. De definitie van EIP Focus Group voor korte ketens gaat bijvoorbeeld over zo min mogelijk schakels, over transparantie, eerlijkheid en partnerschap (EIP-Agri, 2015). Het betreft dus een meer inhoudelijk omschrijving dan de EU-definitie, en het sluit meer aan op thema's zoals marges in de keten, zeggenschap en onderhandelingsperspectief voor de boer (Van der Schans en Van Wonderen, 2019).

\section{Rabobank Nederland}

In Rabobank (2020) wordt het volgende vermeld:

'Er is een veelvoud aan definities voor korte ketens, van minder schakels tussen boer en consument tot minder $\mathrm{km}$ tussen productielocatie en locatie van aankoop/consumptie. De definitie van de korte keten is sterk afhankelijk van het uiteindelijk doel dat men met de "korte keten" voor ogen heeft. Voor de Rabobank is de "korte keten" dan ook een middel om een bepaald doel te bereiken en bepaalt de doelstelling de uiteindelijke definitie en inrichting van de korte keten. De brede doelstelling die Rabobank voor ogen heeft is het realiseren van een duurzamer verdienmodel voor agrarisch ondernemers en een betere verbinding met de consument.'

De stichting Taskforce Korte Keten (TKK) ondersteunt en versterkt de regionale dynamiek van korte voedselketens door kennis te delen, ontwikkeling te faciliteren en het momentum van korte ketens zo goed mogelijk te benutten. De Taskforce wil de ketens verkleinen en ondernemers daarbij helpen hun groei te realiseren. De TKK volgt de beschrijvende EU-definitie in Verordening (EU) nr. 1305/2013, artikel $2 \mathrm{~m}$ ):

'Een korte voedselketen is een toeleveringsketen met een beperkt aantal marktdeelnemers die zich inzetten voor samenwerking, lokale economische ontwikkeling en nauwe geografische en sociale betrekkingen tussen voedselproducenten, -verwerkers en consumenten.'

Deze definitie gaan de provincies en het ministerie van LNV ook hanteren. De definitie is opgenomen in de roadmap die de TKK heeft gemaakt in opdracht van LNV en de provincies voor een verdere ontwikkeling van de korte keten in Nederland.

${ }^{5}$ Een EIP-AGRI (Agricultural European Innovation Partnership) Focus Group is een tijdelijke groep van geselecteerde deskundigen op een specifiek thema, met als doel delen van kennis en ervaringen. 
Andere kenmerken die vaak genoemd worden in definities van korte keten/c.q. de kenmerken (beelden) die men daarbij voor ogen heeft (onder andere in provinciale sessies in dit onderzoek) zijn: producten rechtstreeks op het bord, regionale producten (een relatief beperkte geografische afstand, bijvoorbeeld $40 \mathrm{~km}$ of producten uit de provincie inclusief aangrenzende gebieden van andere provincies), alles van Nederlandse bodem (dus Nederland als regio), transparantie in de keten, producten met extra aaibaarheid, producenten hebben echt invloed op prijs, de versheid van producten, het meenemen van de consument in het productieproces op het bedrijf (het ervaren van de passie van de boer of tuinder, het horen of lezen van het verhaal achter de productie door de boer of tuinder, oftewel het personaliseren van voedsel/van ons eten.

In de publicatie Korteketenproducten in Nederland: Zijn horeca, catering en supermarkten geïnteresseerd in producten uit de regio? (Tacken, et al. 2021), het onderzoek uitgevoerd door Wageningen Economic Research waarin de verkoopkanalen van producten uit korte ketens centraal staat, wordt de volgende definitie aangehouden (vooral vanuit oogpunt van de verkoopkanalen):

'Korte toeleveringsketen: een toeleveringsketen bestaande uit een beperkt aantal marktdeelnemers die streven naar samenwerking, plaatselijke economische ontwikkeling en nauwe geografische en sociale betrekkingen tussen producenten, verwerkers en consumenten, waarbij er geen of maximaal twee ketenpartijen tussen de boer en de consument aanwezig zijn en waarbij de boer als afzender van het product herkenbaar is voor de consument. ${ }^{6}$

\subsection{Methodiek}

Deze monitor bevat gegevens over agrarische bedrijven met afzet via een korte keten (aantallen, bedrijfstype, bedrijfskenmerken, locatie van het bedrijf. Daarnaast wordt inzicht gegeven in het aandeel van de omzet verkregen via een korte keten in de totale bruto-opbrengst van het bedrijf. Op basis van laatstgenoemde wordt een globale indicatie gegeven van de totale opbrengst die gepaard gaat met afzet via korte ketens.

De bron voor deze nulmeting van de monitor korte ketens is de Landbouwtelling. De Landbouwtelling makt deel uit van de gecombineerde opgave, die onder meer gebruikt wordt voor de uitvoering van het landbouwbeleid en handhaving van de Meststoffenwet. De gegevens over korte ketens hebben betrekking op de periode april tot en met maart voorafgaand aan de Landbouwtelling.

Met ingang van 2016 wordt voor de afbakening van de Landbouwtelling gebruikgemaakt van informatie uit het Handelsregister. Inschrijving in het Handelsregister met een agrarische SBI (Standaard Bedrijfsindeling) is leidend bij de bepaling of er sprake is van een landbouwbedrijf. Met deze afbakening wordt zo nauw mogelijk aangesloten bij de statistische verordeningen van Eurostat en de (Nederlandse) implementatie van het begrip 'actieve landbouwer' uit het Gemeenschappelijk Landbouwbeleid (GLB). ${ }^{7}$

De cijfers over korte ketens op basis van de Landbouwtelling kunnen een onvolledig beeld geven, onder andere omdat steeds meer ondernemers hun bedrijven (als gevolg van bijvoorbeeld wetgeving, fiscale voordelen, of risicospreiding) splitsen in meerdere zelfstandige bedrijven met vaak een eigen rechtsvorm (veelal een bv) en boekhouding. Deze bedrijven komen mogelijk niet of onvolledig in beeld via de Landbouwtelling. Dit komt relatief veel voor bij agrarische bedrijven met multifunctionele activiteiten (zie ook Van der Meulen et al., 2019), zoals recreatie, zorg, en huisverkoop.

6 Toelichting hierop in Tacken et al. (2021): Ondanks dat bepaalde producten geen bewerking nodig hebben, verwachten afnemers, zoals horeca en retail, van ondernemers dat ze een sortering van producten of bewerking van producten voor hun rekening nemen. Hiervoor is specialistische expertise nodig, die boeren niet hebben en afnemers niet altijd hebben. Dus in de praktijk bestaan korte ketens, met uitzondering van de boerderijverkoop, vaak uit 2 schakels tussen boer en consument. Daarvan heeft 1 schakel een logistieke en verwerkende of sorteerfunctie en hebben horeca of retail de contacten met de consument.

7 Bron: https://www.cbs.nl/nl-nl/onze-diensten/methoden/onderzoeksomschrijvingen/korteonderzoeksbeschrijvingen/landbouwtelling; 
In 2020 is zowel 'rechtstreekse verkoop aan de consument' als 'verkoop via 1 tussenschakel' opgevraagd (zie ook bijlage 1). Gezamenlijk vormen ze de cijfers voor korte ketens. Eerder zijn in 2016, als onderdeel van verbredingsactiviteiten op het bedrijf, gegevens over rechtstreekse verkoop aan de consument (huisverkoop) opgevraagd. In 2017 is als extra vraag specifiek gevraagd naar de afzet van agrarische producten via geen of 1 tussenschakel.

In deze monitor staan data uit de Landbouwtelling 2020 centraal. Het betreft in deze nationale nulmeting de definitieve cijfers 2020. In de laatste fase van dit onderzoek zijn voorlopige cijfers vervangen door definitieve cijfers. Waar dit niet heeft plaatsgevonden staat voorlopige cijfers 2020 onder de figuur of tabel vermeld (met name in de bijlagen). De factsheets per provincie zijn evenwel gebaseerd op voorlopige cijfers 2020. Hierdoor kunnen er relatief kleine verschillen aanwezig zijn tussen cijfers voor provincies in deze nationale rapportage en in de provinciale factsheets.

Ten aanzien van aantallen korteketenbedrijven is een vergelijking gemaakt met 2017, waarmee inzicht wordt verkregen in de ontwikkeling tussen 2017 en 2020 (onder andere op bedrijfstype niveau, op provinciaal niveau). Voor de vraag in de Landbouwtelling over de opbrengstenkant van korte ketens wordt in deze monitor alleen ingegaan op de gegevens van 2020, en wordt geen vergelijking gemaakt met 2017. Alleen bedrijven die producten rechtstreeks afzetten of via 1 tussenschakel, de zogenaamde korteketenbedrijven, hebben deze vraag in de Landbouwtelling ingevuld, die als volgt luidt:

'Wat is het percentage opbrengst uit verkoop via korte ketens ten opzichte van de totale bruto-opbrengst van het bedrijf (inclusief subsidies).' En is dit aandeel: minder dan 10\%; tussen 10-30\%; tussen 30-50\%; meer dan 50\%?

De boer of tuinder zal bij het invullen van het percentage van deze korteketenvraag in de Landbouwtelling voor het begrip bruto-opbrengsten uitgaan van een zo goed mogelijke benadering van de werkelijke bruto-opbrengst. Echter, de hoogte van dit bedrag wordt niet gevraagd in de telling en is dus niet beschikbaar.

Om de hoogte van de bruto-opbrengsten van ieder korte keten bedrijf zo goed mogelijk te benaderen, is gebruikgemaakt van het begrip Standaardopbrengst (SO), zie Wisman (2021). Voor ieder bedrijf in de Landbouwtelling wordt namelijk het volgende berekend: een gestandaardiseerde opbrengst (in euro) per ha of per dier die met een gewas of diercategorie gemiddeld op jaarbasis wordt behaald. Deze SO-normen per dier of gewas zijn gebaseerd op genormaliseerde vijfjaargemiddelde opbrengsten. Omdat in de Landbouwtelling voor alle gewassen en dieren de aantallen opgegeven worden, kan de totale Standaardopbrengst (SO) voor een bedrijf worden berekend. Opbrengsten uit bedrijfstoeslagen en subsidies zijn niet in deze SO-norm meegenomen, ook wordt geen rekening gehouden met managementkwaliteiten tussen ondernemers. Wel is in de SO de opbrengstwaarde intern verkeer meegenomen, die weer niet is opgenomen in de werkelijke opbrengsten (behalve voorraadverschillen). Hierdoor kunnen er jaarlijks afwijkingen zijn tussen de gestandaardiseerde opbrengst en werkelijke opbrengst zowel op bedrijfsniveau als op groepsniveau (bedrijfstype). Deze afwijkingen lopen per bedrijfstype uiteen.

In dit onderzoek zijn de berekende gestandaardiseerde SO-normen voor bedrijven per bedrijfstype (via de bron Landbouwtelling) vergeleken met de werkelijke bedrijfsopbrengsten per bedrijfstype (bron: Bedrijveninformatienet van Wageningen Economic Research). Dit is uitgevoerd voor een periode van 4 jaar (2016-2019). De verhoudingsfactor per hoofdbedrijfstype tussen de werkelijke opbrengsten (een gewogen gemiddelde van bedrijven uit het Bedrijveninformatienet) en de Standaardopbrengsten (SO) is eerst berekend. Deze verhoudingsfactor is vervolgens per bedrijfstype aangepast voor de subgroep korte keten bedrijven, waar alleen de SO 2017 bekend is en het \% opbrengsten uit afzet korte ketens in 2017. De daaruit voortkomende correctiefactor is vermenigvuldigd met de berekende SO per bedrijf en het \% opbrengsten korte keten per bedrijf in 2020 (dit is per bedrijfstype toegepast) om tot een zo goed mogelijke indicatie te komen van de werkelijke opbrengsten korte keten in 2020. In formulevorm:

Verhoudingsfactor $r_{\text {bedrijfstype }}=\frac{\text { Werkelijke opbrengst } 2016-2019_{\text {bedrijfstype }}}{\text { Standaard opbrengst } 2016-2019_{\text {bedrijfstype }}}$ 


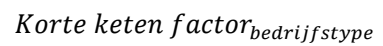

$=\frac{(\text { Werkelijke opbrengst } 2017 \text { korte keten/Standaard opbrengst } 2017 \text { korte keten })_{\text {bedrijfstype }}}{(\text { Werkelijke opbrengst } 2017 \text { /Standaard opbrengst 2017 })_{\text {bedrijfstype }}}$

Correctiefactor $_{\text {bedrijfstype }}=$ Verhoudingsfactor $_{\text {bedrijfstype }} \cdot$ Korte keten factor $_{\text {bedrijfstype }}$

Opbrengst korte keten bedrijfstype

$=(\text { Standaard opbrengst } 2020 \cdot \% \text { opbrensten korte keten })_{\text {bedrijfstype }}$

- Correctiefactor ${ }_{\text {bedrijfstype }}$

Het bedrijfshoofd op de korteketenbedrijven heeft op de vraag 'het percentage opbrengst uit verkoop via korte ketens ten opzichte van de totale bruto-opbrengst' een van de vier aangegeven klassen ingevuld. Voor berekening van de opbrengst op bedrijfsniveau is voor alle bedrijven die de klasse minder dan $10 \%$ hebben ingevuld, uitgegaan van het gemiddelde van deze range, namelijk $5 \%$. Voor de overige 3 klassen, tussen 10-30\%; tussen 30-50\%; meer dan 50\%, is dat gemiddelde respectievelijk $20 \%$, $40 \%$ en $75 \%$. Zie voor de resultaten opbrengstschatting paragraaf 3.6.

\section{Aantallen bedrijven}

In de Landbouwtelling 2020 hebben in totaal 7.234 agrarische bedrijven ingevuld via geen of 1 schakel producten aan de consument te verkopen (tabel 2.1). Van deze bedrijven geeft ruim $70 \%$ ( 5.127 bedrijven) aan een deel van hun producten rechtstreeks aan de consument te verkopen. Daarnaast geeft 53\% (3.833 bedrijven) aan via 1 tussenschakel hun voedings- of sierteeltproduct aan de consument te verkopen. Deze groepen zijn op te splitsen in 3.401 bedrijven die uitsluitend rechtstreeks aan de consument verkoopt, 2.107 bedrijven die uitsluitend via 1 tussenschakel verkopen, en 1.726 bedrijven die naast verkoop via 1 tussenschakel eveneens rechtstreeks verkopen.

Provincie Flevoland is de provincie waarin het aandeel bedrijven met rechtstreekse verkoop het laagst ligt: $56 \%$. In Limburg en Utrecht ligt dit aandeel met $78 \%$ het hoogst.

Tabel 2.1 Aantal korteketenbedrijven, met rechtstreekse verkoop aan consument en verkoop via 1 tussenschakel, ingedeeld naar provincies, 2020

\begin{tabular}{lrrr} 
Provincies & Rechtstreeks a) & via 1 tussenschakel b) & totaal via korte keten \\
Drenthe & 242 & 152 & 320 \\
\hline Flevoland & 123 & 149 & 219 \\
\hline Friesland & 228 & 210 & 351 \\
\hline Gelderland & 850 & 570 & 1.139 \\
\hline Groningen & 176 & 123 & 244 \\
\hline Limburg & 570 & 354 & 732 \\
\hline Noord-Brabant & 1.015 & 703 & 1.376 \\
\hline Noord-Holland & 410 & 374 & 654 \\
\hline Overijssel & 397 & 302 & 566 \\
\hline Utrecht & 262 & 172 & 334 \\
\hline Zeeland & 340 & 210 & 451 \\
\hline Zuid-Holland & 514 & 514 & 848 \\
\hline Totaal Nederland & 5.127 & 3.833 & 7.234 \\
\hline
\end{tabular}

a) Inclusief bedrijven die ook via 1 tussenschakel verkopen;

b) Inclusief bedrijven die ook rechtstreeks verkopen. Bron: Landbouwtelling.

Kijken we naar de bedrijfstypen, dan zie we in onder andere voor de blijvende teelt (82\%) en leghennenhouderij (86\%) hoge scores voor het aandeel bedrijven dat rechtstreeks aan de consument verkoopt (tabel 2.2). Producten als vele fruitsoorten en eieren hebben nauwelijks bewerkingsslagen nodig om geconsumeerd te worden, en worden veel rechtstreeks verkocht. Dit geldt ook voor meerdere producten in de glastuinbouw (potplanten, groenten, bloemen), alleen vindt daar ook veel reguliere handel via 1 tussenschakel plaats, waardoor het aandeel rechtstreeks lager blijft. 
Tabel 2.2 Aantal korteketenbedrijven, met rechtstreekse verkoop aan consument en verkoop via 1 tussenschakel, ingedeeld naar hoofdbedrijfstypen, 2020

\begin{tabular}{|c|c|c|c|}
\hline Hoofdbedrijfstypen & Rechtstreeks a) & via 1 tussenschakel b) & via korte keten \\
\hline Akkerbouw & 654 & 504 & 946 \\
\hline Blijvende teelt & 556 & 369 & 683 \\
\hline Leghennen & 255 & 100 & 283 \\
\hline Melkvee & 713 & 670 & 1.146 \\
\hline Overig landbouw & 687 & 413 & 891 \\
\hline Overig tuinbouw & 927 & 798 & 1.365 \\
\hline Totaal & 5.127 & 3.833 & 7.234 \\
\hline
\end{tabular}

a) Een deel van de bedrijven dat rechtstreeks verkoopt, verkoopt eveneens via 1 tussenschakel.

b) Een deel van de bedrijven dat via 1 tussenschakel verkoopt, zet eveneens rechtstreeks af. Bron: Landbouwtelling.

\section{Bedrijfstype}

De land- en tuinbouwbedrijven kunnen worden ingedeeld naar bedrijfstypen. Omdat in de blijvende teelt (fruitteelt, wijngaarden) en leghennenhouderij relatief veel korte ketens aanwezig zijn, is voor deze monitor de volgende hoofdindeling aangehouden:

- tuinbouwsectoren: blijvende teelt, glastuinbouw en overig tuinbouw

- landbouwsectoren: akkerbouw, melkveehouderij, leghennenhouderij, overig graasdierhouderij, overig landbouw

Hiermee wijkt de indeling in deze monitor af van de NSO-typering. Voor nader inzicht wordt verwezen naar bijlage 1 . 


\section{$3 \quad$ Resultaten monitoring korteketenbedrijven}

\subsection{Inleiding}

In dit hoofdstuk wordt inzicht gegeven in de huidige situatie (in 2020) van primaire agrarische bedrijven met (gedeeltelijke) afzet van producten via een korte keten. In deze monitor worden deze bedrijven bestempeld als korteketenbedrijven. Ook wordt ingegaan op de opgetreden ontwikkeling sinds 2017. Aan de orde komen aantallen bedrijven, kenmerken van deze bedrijven en de regionale spreiding. Daarnaast wordt voor 2020 een globale inschatting gegeven van de gerealiseerde omzet die gepaard gaat met afzet via een korte keten.

\subsection{Naar bedrijfstype}

Nederland heeft in 2020 bijna 52.700 primaire agrarische bedrijven. Dit zijn bedrijven die de Landbouwtelling 2020 hebben ingevuld. Hierbij geldt een ondergrens van meer dan 3000 aan standaardopbrengsten (zie bijlage 1). Ongeveer 13,7\% (7.234) van deze primaire agrarische bedrijven zet een deel van de producten (voeding en sierteelt) af via een korte keten (tabel 3.1). Deze worden in deze monitor bestempeld als korteketenbedrijf.

\section{Aandeel korte ketens in de tuinbouw hoog}

Het aandeel korte ketenbedrijven is in de tuinbouw het hoogst voor het bedrijfstype blijvende teelt. Bijna de helft van deze overwegend fruitteeltbedrijven zet af naar de consument via geen of maximaal 1 tussenschakel. Een kleine subgroep zijn de in opkomst zijnde wijngaarden: vier op de vijf bedrijven is een korteketenbedrijf.

Ook de andere onderscheiden tuinbouwtypen, de glastuinbouw en de verzamelgroep overig tuinbouw, scoren relatief hoog. Ruim een kwart van de glastuinbouwbedrijven typeert zichzelf als een korteketenbedrijf. Hieronder veel bedrijven met afzet die via 1 tussenschakel bij de consument terechtkomt. Voor de achterliggende gespecialiseerde typen glasgroente en pot- en perkplantenteelt is dit aandeel bijna een derde (bijlage 3, tabel B3.1). De snijbloementeelt onder glas blijft daarbij achter $(18 \%)$.

De overige tuinbouw is een verzamelgroep van meerdere bedrijfstypen. Voor drie van de binnen deze groep vallende bedrijfstypen ligt het aandeel korteketenbedrijven boven een derde: opengrondsgroente (39\%), paddenstoelenteelt (37\%) en boomkwekerij (33\%). De bloembollenteelt blijft steken op $15 \%$, iets boven het eerder aangehaalde nationale gemiddelde van 13,7\%.

In de landbouw relatief minder korteketenbedrijven, uitgezonderd de leghennenhouderij De aandelen korteketenbedrijven in de bedrijfstypen gericht op veehouderij blijven vooral onder het nationale gemiddelde $(13,7 \%)$. Een uitzondering is de leghennenhouderij. Op meer dan de helft van deze bedrijven is er bij de afzet van producten een korte verbinding tussen producent en consument. Dit is een van de bedrijfstypen met een product (consumptie-eieren) waarbij nauwelijks of weinig bewerkingsslagen plaatsvinden voordat het product aan de eindconsument kan worden verkocht. Dit gaat naast eieren, bijvoorbeeld ook voor fruit, en voor meerdere glasgroenten en opengrondsgroenten, en champignons. Het fruit dat je als producent plukt is het fruit dat je als consument koopt; het ei dat je als producent raapt is het ei dat je als consument koopt. Ondernemers hoeven nauwelijks/beperkt te investeren in verwerkingscapaciteit en kunnen dus eenvoudiger dan veel collega's uit andere bedrijfstypen, instappen in de korteketeneconomie (Van der Schans en Van Wonderen, 2019). 
Tabel 3.1 Aantallen agrarische bedrijven, korteketenbedrijven en het aandeel korteketenbedrijven in Nederland, 2020

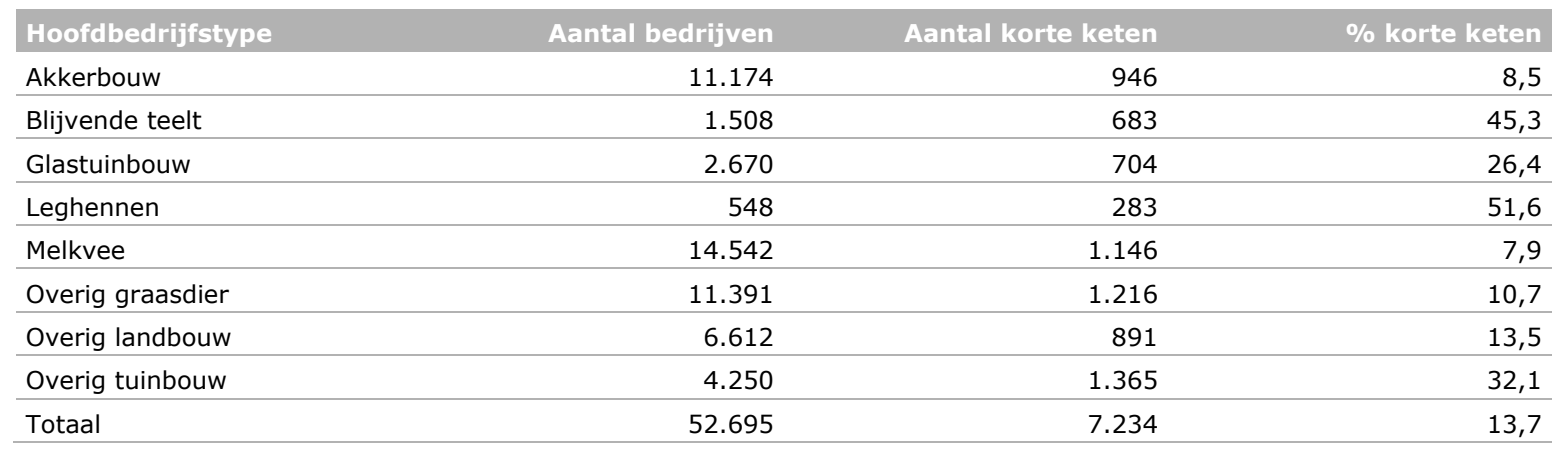

Bron: Landbouwtelling.

Dit is mede een reden dat er binnen andere veehouderijtypen (zoals geitenbedrijven, melkveebedrijven, schapenbedrijven, vleeskalverenbedrijven, vleeskuikenbedrijven en vleesvarkensbedrijven) relatief weinig korteketenbedrijven worden geteld.

Op de ruim 14.500 gespecialiseerde melkveebedrijven heeft $8 \%$ van de bedrijfshoofden ingevuld een korte keten bedrijf te zijn. Ondanks dit relatief lage percentage gaat het wel om bijna 1.150 bedrijven, $16 \%$ van het volledige aantal korteketenbedrijven in Nederland.

Het aandeel in de verzamelgroep overig graasdier ligt met ruim $10 \%$ iets hoger dan in de melkveehouderij. Binnen deze groep scoren de achterliggende bedrijfstypen geitenhouderij (18\%), de schapenhouderij (13\%) en de qua aantallen bedrijven grootste groep Overig Rundvee (13\%) het hoogst. De paarden-/ponybedrijven blijven steken op ruim $7 \%$.

De akkerbouw, in Nederland een grote tak met bijna 11.200 bedrijven, zet ongeveer 1 op de 12 bedrijven agrarische producten af via maximaal 1 schakel.

Het hoofdbedrijfstype dat resteert is de verzamelgroep overig Landbouw. Binnen de verschillende bedrijfstypen die hieronder vallen lopen de aandelen korteketenbedrijven sterk uiteen: van ruim $30 \%$ op de gewascombinatiebedrijven, tot $4 \%$ voor zowel de vleesvarkenshouderij als de vleeskuikenhouderij (zie bijlage 3, tabel B3.1). De gewas-veecombinaties (18\%) en de veeteeltcombinaties (16\%) zitten enkele procentpunten boven het nationale niveau.

\subsection{Ontwikkeling 2017-2020}

In 2017 is voor het eerst in de Landbouwtelling gevraagd naar de afzet via geen of maximaal 1 schakel. Figuur 3.1 geeft de ontwikkeling weer in het percentage korteketenbedrijven in de 3-jaarlijkse periode 2017-2020. In 2017 zijn 5.735 bedrijven bestempeld als een korteketenbedrijf. Dit aantal is met ruim een kwart toegenomen tot 7.234 bedrijven in 2020 . Omdat ieder jaar ongeveer $2 \%$ van de agrarische bedrijven stopt en dus niet langer zichtbaar is in de telling, is het ook relevant te kijken wat de ontwikkeling is van het aandeel korteketenbedrijven in het totaal. Voor de totale land- en tuinbouw zien we dat dit aandeel is gestegen van 10,5\% naar 13,7\%. Ook laat figuur 3.2. zien dat de toename van het aandeel in alle onderscheiden hoofdbedrijfstypen op is getreden. Relatief zien we de sterkste toename in de glastuinbouw en de overige tuinbouw. In de grondgebonden bedrijfstypen is de ontwikkeling beperkt tot enkele procentpunten (akkerbouw +1 ), melkvee +2 ). De blijvende teelt is veruit het bedrijfstype dat het hoogste aandeel scoort, en de afgelopen jaren zelfs iets verder door stijgt naar ruim $45 \%$. 


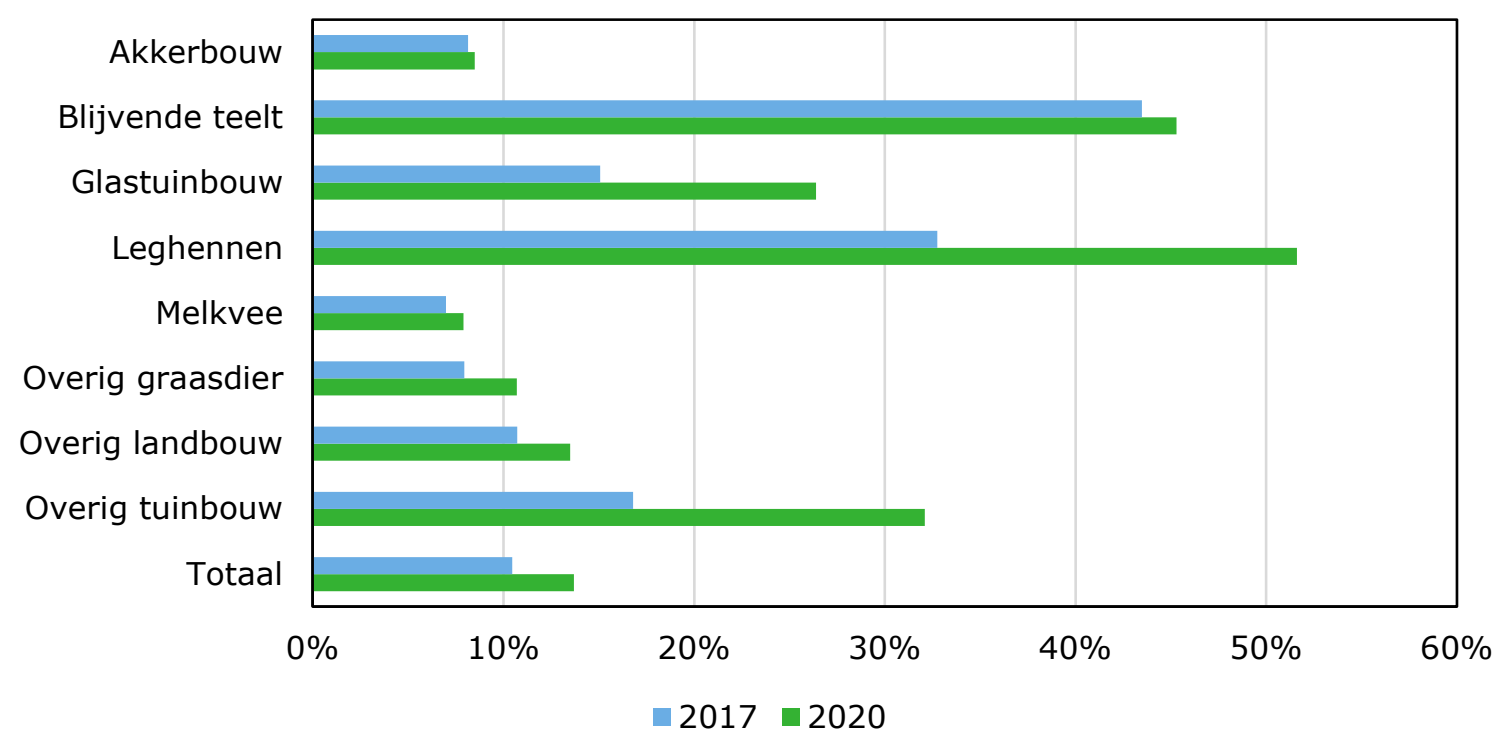

Figuur 3.1 Ontwikkeling aandeel korte ketens voor de onderscheiden hoofdbedrijfstypen, 2017-2020 Bron: Landbouwtelling.

De ontwikkeling van het aantal korteketenbedrijven heeft vooral plaatsgevonden op de qua omvang (in SVC= standaardverdiencapaciteit) ${ }^{8}$ zeer kleine bedrijven: van ruim 1.600 korteketenbedrijven in 2017, naar bijna 2.380 bedrijven in 2020 (figuur 3.2). Ook binnen de als zeer groot bestempelde groep was een sterke stijging zichtbaar, evenals voor de groep kleine bedrijven. In totaal leveren bijna 2.390 grote en zeer grote bedrijven afzet via een korte keten. In 2017 betrof het in totaal 2.160 bedrijven, een toename van 230 omvangrijke (in SVC gemeten) bedrijven in drie jaar tijd.

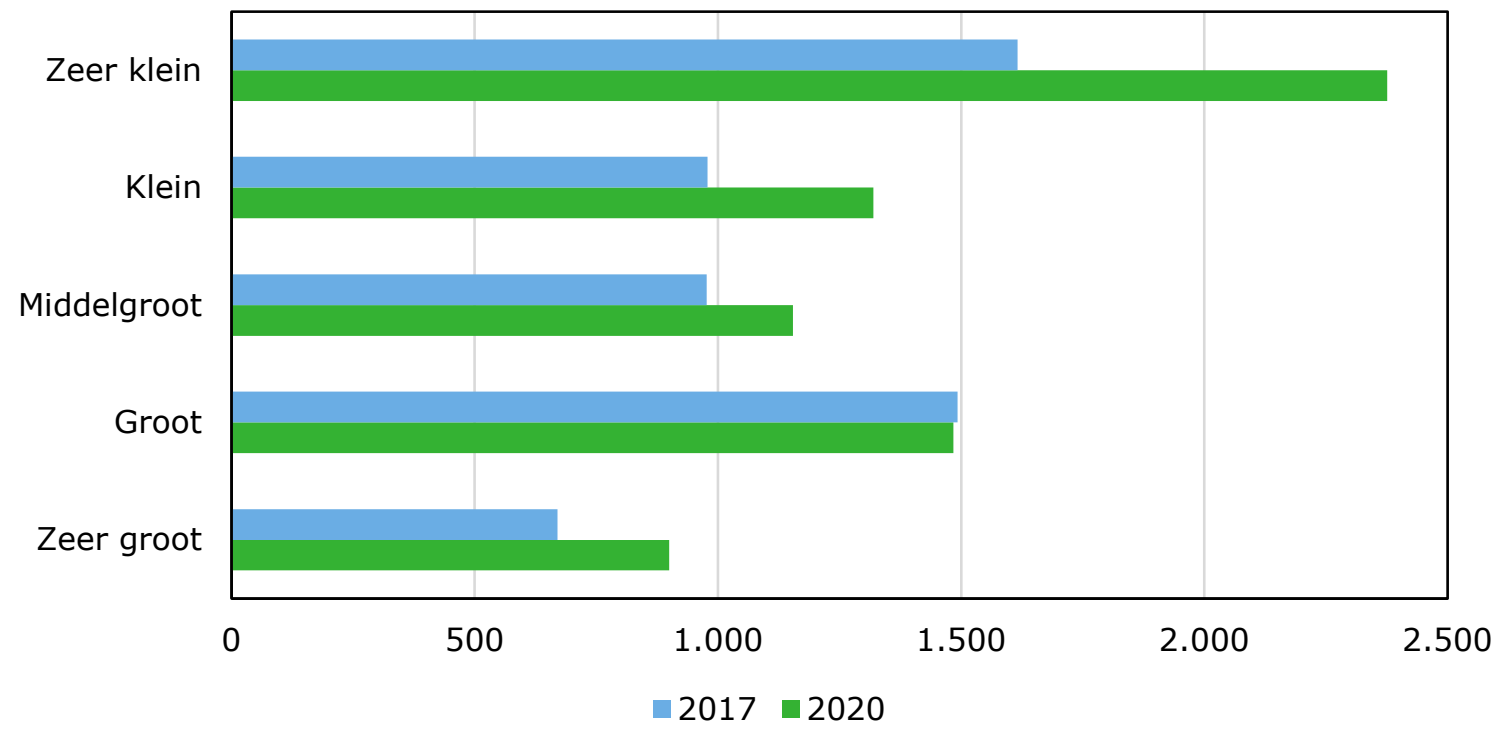

Figuur 3.2 Ontwikkeling aantal korteketenbedrijven naar economische omvang klasse (in standaardverdiencapaciteit (SVC)), 2017-2020

Bron: Landbouwtelling.

\footnotetext{
${ }^{8}$ Zie bijlage 1 voor definitie SVC en toelichting op onderscheiden grootteklassen.
} 


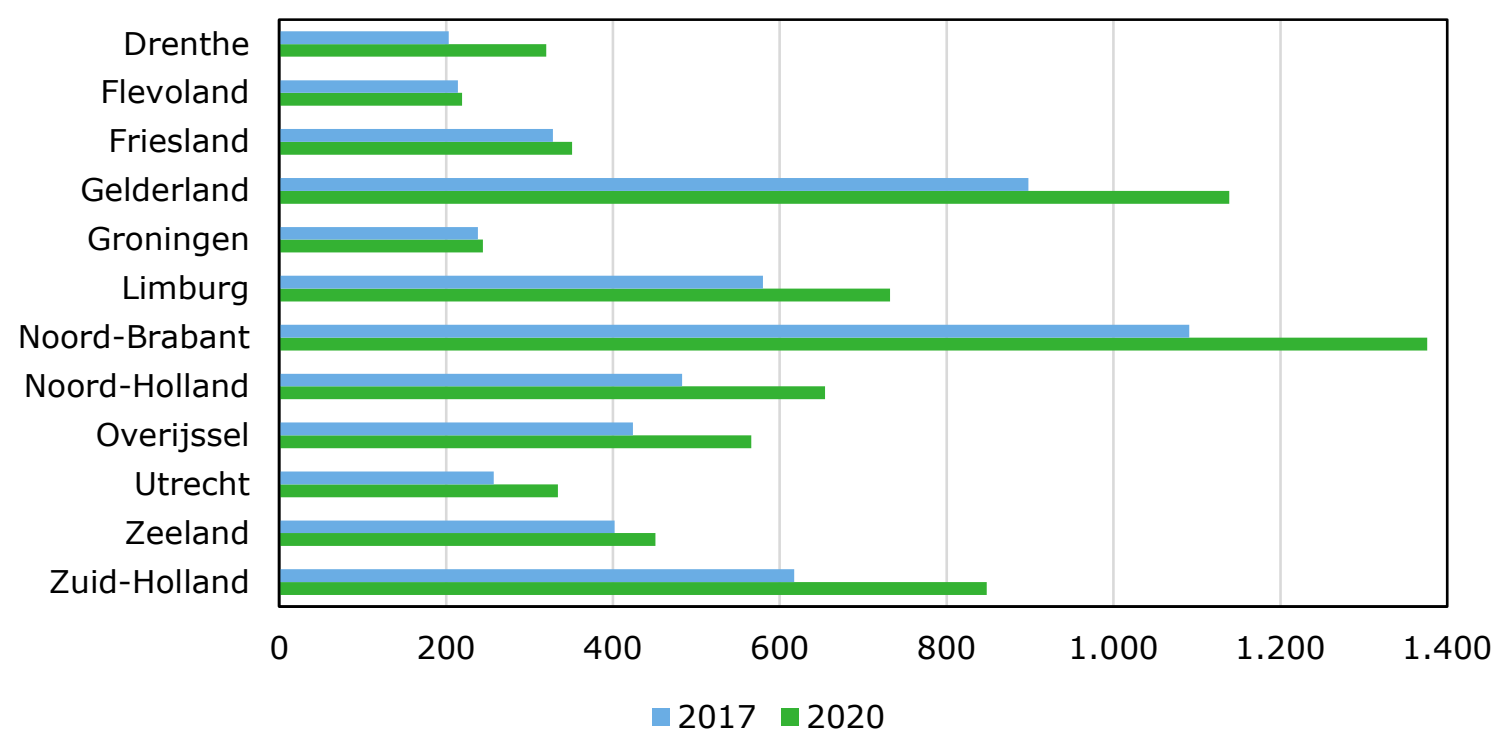

Figuur 3.3 Ontwikkeling aantal korteketenbedrijven per provincie, 2017-20209 Bron: Landbouwtelling.

In alle provincies is het aantal korteketenbedrijven toegenomen (figuur 3.3). Dit is ondanks de jaarlijkse structurele afname van agrarische bedrijven met gemiddeld 2 à 3 procentpunten door onder andere geen geschikte opvolger of financiële problemen (vaak wordt zo'n bedrijf opgekocht door naburige collega's) of verandering van beroep. De toename van het aantal korteketenbedrijven is het sterkst in de provincies Noord-Brabant, Gelderland en Zuid-Holland, ook provincies met het grootste aantal land- en tuinbouwbedrijven. Dat zijn overigens ook de provincies met het grootste aantal landen tuinbouwbedrijven. De toename van het aantal bedrijven met afzet via korte ketens was het geringst in de provincies Friesland, Groningen en Flevoland.

De ontwikkeling van het aandeel korteketenbedrijven per provincie wordt weergegeven in figuur 3.4. Koploper in het aandeel korteketenbedrijven (in totaal aanwezige bedrijven) is de provincie Limburg: een op de vijf bedrijven heeft ingevuld via geen of maximaal 1 schakel te leveren aan de consument (in 2017 15\%). Limburg wordt op de voet gevolgd door Noord-Holland en Zuid-Holland: beide met een aandeel van $19 \%$, in beide provincies een toename van rond de 6 procentpunten. Ook de provincies Zeeland, Noord-Brabant en Utrecht scoren hoger dan het landelijke percentage, en zien we dat de aandelen korteketenbedrijven met tussen de 2 en 4\% stijgen. De provincies Gelderland en Flevoland zitten met een aandeel rond de $13 \%$ iets beneden het nationale niveau. In Gelderland stijgt het aandeel met 3 procentpunten. Drenthe volgt met $11,6 \%$, maar is de provincie waar korteketenbedrijven relatief het sterkst zijn toegenomen (in 2017: ruim 7\%). In de drie overige provincies, Groningen, Friesland en Overijssel heeft minder dan een op de tien bedrijfshoofden aangegeven binnen een korte keten af te zetten. In alle drie de provincies neemt het aandeel toe, het sterkst in Overijssel ( $+2,4$ procentpunten).

Voor meer inzicht in de positie van korteketenbedrijven in de provincies wordt verwezen naar de provinciale factsheets. Hierin wordt per provincie een beschrijving gegeven van de huidige situatie (2020) op de primaire agrarische bedrijven met (gedeeltelijke) afzet van producten via een korte keten. Ook wordt ingegaan op de opgetreden ontwikkeling sinds 2017. Aan de orde komen aantallen bedrijven, kenmerken van deze bedrijven en de regionale spreiding. Ook wordt een globale inschatting gegeven van de gerealiseerde omzet die gepaard gaat met afzet via een korte keten. ${ }^{10}$

\footnotetext{
9 Zie voor precieze aantallen per provincie bijlage 3, tabel B3.3 en de factsheets per provincie.

${ }^{10}$ Via provinciale ambtenaren zijn informanten gevonden met een betrokkenheid bij korte ketens in hun provincie. Deze personen hebben commentaar gegeven op de provinciale cijfers en ontwikkelingen uit de landbouwtelling. Dit is gedaan in eenmalige sessie bijeenkomst zonder verdere voorbereiding. Ook hebben de genodigde personen huidige belemmeringen en mogelijke kansen benoemd. In de factsheets wordt een aantal van deze belemmeringen en kansen vermeld.
} 


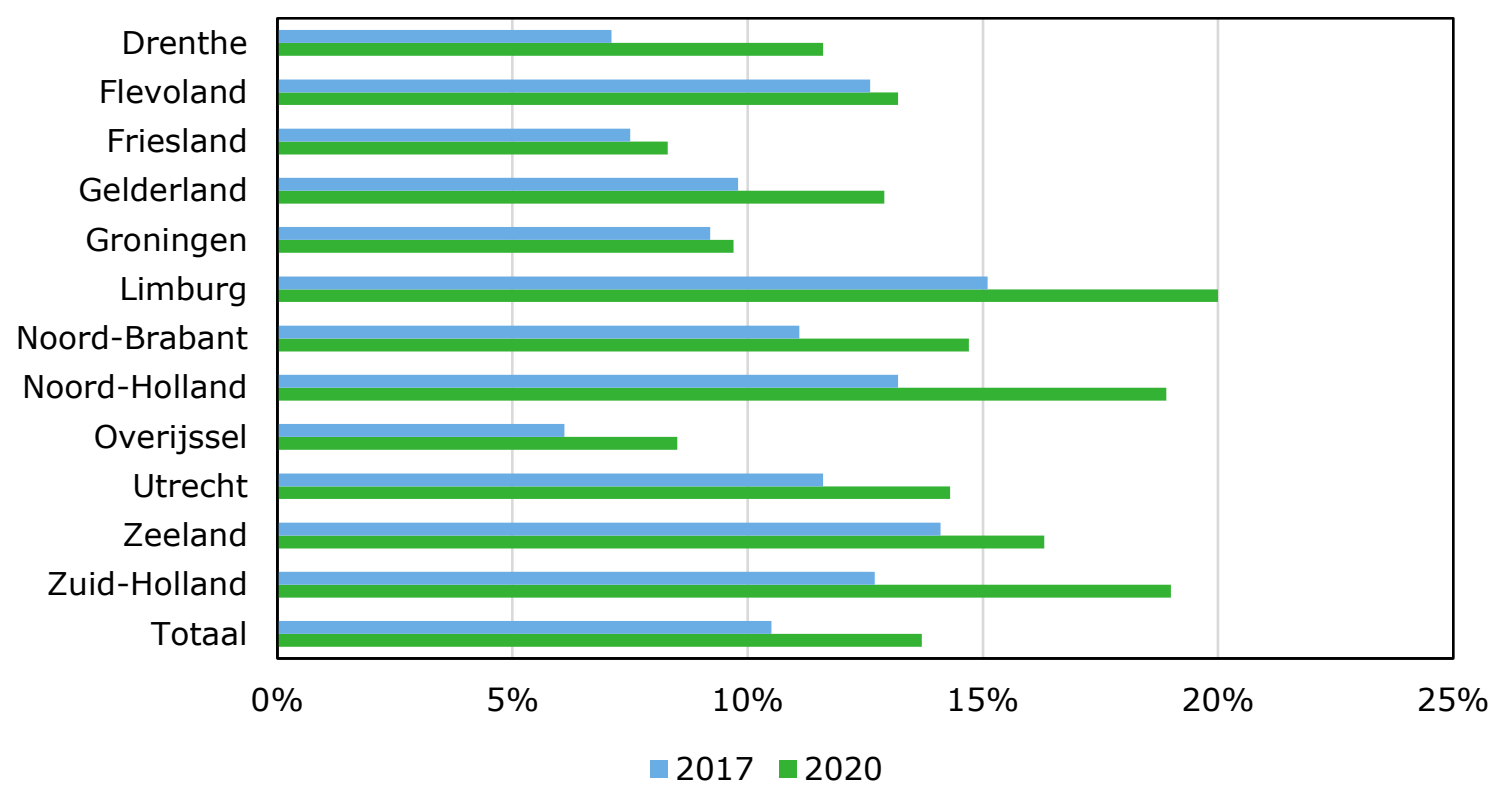

Figuur 3.4 Ontwikkeling aandeel korteketenbedrijven per provincie, 2017-2020 Bron: Landbouwtelling.

\subsection{Kenmerken korteketenbedrijven}

Een belangrijk deel van de primaire agrarische bedrijven in Nederland is qua economische omvang (in SVC) zeer klein (19294 bedrijven, tabel 3.2). Ongeveer een op de acht van deze groep bedrijven is een korte keten bedrijf. In de andere grootteklassen ligt dit aandeel gelijk (middelgrote bedrijven), iets hoger (klein en groot) of duidelijk hoger (de zeer grote bedrijven). Binnen laatstgenoemde groep is een op de vijf bedrijven een korteketenbedrijf. Hieronder zijn relatief veel glastuinbouwbedrijven die afzetten via maximaal 1 schakel.

Verreweg de meeste bedrijven in Nederland hebben een bedrijfshoofd in de leeftijdscategorie van 50 tot 65 jaar oud (bijna 27.000 bedrijven, tabel 3.2). Toch is dit niet de leeftijdscategorie waar procentueel gezien de meeste korteketenbedrijven zich in bevinden. Dit is de leeftijdscategorie jonger dan 40 jaar (17,3\%). Op de 11.781 bedrijven met een bedrijfshoofd vanaf 65 jaar levert een op de 10 bedrijven via een korte keten.

Op bedrijven met een bedrijfshoofd ouder dan 51 jaar wordt in de Landbouwtelling ook de vraag gesteld of er een potentiële bedrijfsopvolger aanwezig is. Op de bedrijven met een potentiële opvolger werkt de opvolger veelal in een samenwerkingsverband met de ouders. Dit is veelal voor een periode van 10 tot 15 jaar waarin vermogensvorming een belangrijk element is om de toekomstige definitieve overname te kunnen financieren. De opvolger werkt meestal als maat in het bedrijf, en heeft ook vaak nog een (parttime)baan buitenshuis. Vaak is dit toch een periode waarin meer gezinsarbeid beschikbaar is en kunnen strategische keuzes gemaakt worden. Bijvoorbeeld om de agrarische tak te vergroten of een ander (bijkomend) verdienmodel op te starten, zoals een korteketeninitiatief of een multifunctionele activiteit. In de cijfers zien we echter dat in deze groep met potentiële opvolger het aandeel bedrijven met afzet via een korte keten (13\%) nog onder het nationale gemiddelde blijft. De groep oudere bedrijfshoofden zonder opvolger blijft daarbij iets achter. In deze groep zitten ook bedrijven die de agrarische tak afbouwen en (tijdelijk) verdienvermogen uit bijvoorbeeld een korte keten initiatief halen. In het algemeen zijn binnen deze groep toekomstige uittreders veel kleine bedrijven. We zagen eerder dat de ontwikkeling van het aantal korteketenbedrijven binnen de groep zeer kleine en kleine bedrijven het sterkst de afgelopen jaren is toegenomen. Het is interessant in nader onderzoek verder in te zoomen naar de kenmerken van de nieuwe korteketenbedrijven. 
Tabel 3.2a Aantal agrarische bedrijven, percentage bedrijven met afzet via korte keten, ingedeeld naar economische omvang (SVC), 2020

\begin{tabular}{lcr} 
SVC-klasse & Aantallen bedrijen & \%orte keten \\
Zeer klein & 19.294 & 12,3 \\
\hline Klein & 9.254 & 14,3 \\
\hline Middelgroot & 9.346 & 12,3 \\
\hline Groot & 10.239 & 14,5 \\
\hline Zeer groot & 4.562 & 19,7
\end{tabular}

a) Grenzen SVC-klassen (standaardverdiencapaciteit) x 1.000 euro: Zeer klein: <25; klein: 25-60; middelgroot: 60-100; groot: 100-220; zeer groot: $>250$

Tabel 3.2b Aantal agrarische bedrijven, percentage bedrijven met afzet via korte keten, ingedeeld naar leeftijd bedrijfshoofd, 2020

\begin{tabular}{lcrr} 
Leeftijd & Aantallen bedrijven & \%orte keten \\
\hline Jonger dan 40 & 4.337 & 17,4 \\
\hline $40-50$ & 9.665 & 16,1 \\
\hline $50-65$ & 26.921 & 14,2 \\
\hline 65 en ouder & 11.781 & 9,3 \\
\hline
\end{tabular}

Tabel 3.2c Aantal agrarische bedrijven, percentage bedrijven met afzet via korte keten, ingedeeld naar continuïteitsituatie, 2020

\begin{tabular}{lrr} 
Continuiteitspositie & Aantal bedrijven & \% korte keten \\
Rechtspersoon & 4.705 & 18,3 \\
\hline Jonger dan 51 jaar & 13.900 & 15,8 \\
\hline$\geq 51$ jaar met opvolger & 13.503 & 13,0 \\
\hline 51 jaar zonder opvolger & 20.603 & 11,7 \\
\hline
\end{tabular}

Bron: Landbouwtelling.

Sterke relatie activiteiten als educatie, zorglandbouw en toerisme met afzet producten via korte keten In Nederland zijn er veel bedrijven die naast de agrarische tak andere activiteiten uitvoeren, zoals agrarisch natuurbeheer ( 8.190 bedrijven) of agro-toerisme (bijna 2.000 bedrijven). Afzet van agrarische producten via een korte keten gaat dikwijls samen met de aanwezigheid van multifunctionele activiteiten op het bedrijf. Zo vindt op bijna 30\% van de bedrijven met agrotoerisme en op meer dan een derde van de zorgboerderijen ook afzet van eigen geproduceerde producten via een korte keten plaats (tabel 3.3). Veelal via huisverkoop of het aanbieden van zorgmaaltijden. Op de bedrijven die aan educatie doen ligt het aandeel korteketenbedrijven nog hoger (43\%). Op de bedrijven met overige multifunctionele activiteiten, zoals opwekking van duurzame energie, agrarisch natuurbeheer, kinderopvang en stalling ligt het aandeel tussen de 14 en $18 \%$. Het is niet verrassend dat bedrijven die zelf producten verwerken, deze producten veelal direct aan de consument verkopen of hooguit via 1 tussenschakel (88\%).

In veel provincies zien we hetzelfde beeld, waarbij een aantal activiteiten, zoals agrotoerisme, in meerdere provincies relatief sterk aanwezig is. In hoeverre de multifunctionele bedrijven ook een korte keten bedrijf zijn (per multifunctionele activiteit bekeken) is terug te vinden in de factsheets per provincie. Al meerdere keren is er een monitor multifunctionele landbouw uitgebracht met aandacht voor de ontwikkeling van aantallen bedrijven, structuurkenmerken bedrijven, en een inschatting opbrengsten uit multifunctionele activiteiten (onder andere huisverkoop). Zie van der Meulen et al. (2019). 
Tabel 3.3 Aantal agrarische bedrijven en percentage bedrijven met afzet via korte keten in Nederland, ingedeeld naar multifunctionele activiteit a), 2020

\begin{tabular}{lrr} 
Activiteit & Aantal bedrijen & 179 \\
agrarische kinderopvang & 1.995 & 14 \\
\hline agrotoerisme & 1.004 & 29 \\
\hline boerderij educatie & 8.190 \\
\hline natuurbeheer & 3.508 \\
\hline opwekking duurzame energie voor levering aan derden & 2.990 \\
\hline stalling van goederen / dieren & 1.167 \\
\hline verwerking landbouwproducten & 701 \\
\hline zorgboerderij & 16 \\
\hline
\end{tabular}

a) Bedrijven kunnen een combinatie van multifunctionele activiteiten hebben, en meegeteld zijn bij meerdere activiteiten; de multifunctionele activiteit huisverkoop is niet meegenomen omdat deze activiteit onderdeel is van de definitie korte keten.

Bron: Landbouwtelling.

Van de 1.826 primaire agrarische bedrijven die in de Landbouwtelling hebben aangegeven een biologisch bedrijf te zijn, zet bijna 39\% van de bedrijven voedsel- en/of sierteeltproducten af via geen of 1 schakel tussen de producent en consument. Op de bedrijven met een gangbare productiewijze is dit duidelijk minder: een op de acht bedrijven. Het aandeel korte ketens in de biologische landbouw ligt dus driemaal zo hoog. Tussen provincies loopt dit percentage uiteen van $23 \%$ in Flevoland tot $49 \%$ in Noord-Brabant. Beide provincies behoren samen met Gelderland tot de top 3-provincies met de grootste aantallen biologische bedrijven. Gelderland is topscorer met 358 biologische bedrijven. Het aandeel korteketenbedrijven is hier $35 \%$.

Het aandeel korte ketens op biologische bedrijven in de provincies heeft ook sterk te maken met de aanwezige bedrijfstypen per provincie: de mate waarin biologisch wordt geproduceerd verschilt per bedrijfstype, de mate van bewerking van producten voordat het kan worden afgezet bij de consument. Zo hebben bijvoorbeeld veel fruitproducten weinig bewerking nodig.

Tabel 3.4 Aantal agrarische bedrijven, percentage bedrijven met afzet via korte keten, ingedeeld naar productiewijze (wel/niet biologisch), 2020

\begin{tabular}{lrr} 
Productiewijze & Aantal bedrijven & \% korte keten \\
geheel biologisch & 1.826 & 38,5 \\
\hline niet biologisch (gangbaar) & 50.869 & 12,8 \\
\hline Bron: Landbouwtelling. & &
\end{tabular}

\subsection{Ruimtelijke verdeling}

De meeste korteketenbedrijven bevinden zich in de provincies Noord-Brabant, Gelderland en ZuidHolland (zie cirkelomvang in figuur 3.5, zie figuur 3.3). In de Noordelijke provincies en in middenNederland zijn de aantallen bedrijven met afzet via een korte keten het laagst. Omdat de aantallen agrarische bedrijven nogal verschillen tussen provincies kan de onderlinge positie van provincies ten aanzien van het kengetal aandeel korteketenbedrijven in totaal bedrijven, anders liggen (zie figuur 3.4).

Ook zijn er aanzienlijke verschillen in de mate van aanwezigheid van de bedrijfstypen per provincie, en daarmee ook (deels) terug in de verdeling van korte ketenbedrijven naar bedrijfstype. Als we naar de drie provincies kijken met de meeste korte ketens, dan valt op dat bijna alle onderscheiden hoofdbedrijfstypen (redelijk) goed vertegenwoordigd zijn. Dit geldt vooral voor de provincie Gelderland. In Zuid-Holland en Noord-Brabant springen wel twee bedrijfstypen eruit. Zo staat de volgende toelichting in de factsheets voor deze provincies:

- Van de 848 korteketenbedrijven in Zuid-Holland is bijna een derde (32,7\%) een glastuinbouwbedrijf. Hieronder vallen zowel glasgroente- (86), snijbloemen- (81), als pot- en perkplantenbedrijven (93). 
Dit varieert van zowel zeer grote telers met directe lijnen naar retail, als bedrijven met verkoop aan de weg/of via winkel.

- Van de 1.375 korte ketenbedrijven in Noord-Brabant valt bijna een derde $(31,6 \%)$ binnen het verzamelbedrijfstype overig tuinbouw. Dit zijn in deze provincie vooral bedrijven in de opengrondsgroenteteelt, de boomkwekerij en in mindere mate champignonteelt.

In meerdere provincies zien we een sterke overheersing van veelal 2 à 3 bedrijfstypen binnen het aantal korteketenbedrijven. Zo omvatten de melkveehouderij en overige graasdierhouderij in de provincies Friesland, Overijssel en Utrecht meer dan de helft van de korteketenbedrijven, op de voet gevolgd door Drenthe (zie figuur 3.5). In Zeeland en de Flevopolders (en in mindere mate Groningen) is de akkerbouw het bedrijfstype met het grootste aantal korteketenbedrijven.

Naast Noord-Brabant, bevinden zich in Noord-Holland en Limburg relatief veel korteketenbedrijven in de groep overig tuinbouw. In Limburg betreft dit vooral boomkwekerijen, opengrondsgroenteteelt en champignonteelt, in Noord-Holland bloembollenteelt, boomkwekerijen en opengrondsgroenteteelt. De korteketenbedrijven in de blijvende teelt (vooral fruitteelt en/of wijngaarden) bevinden zich vooral in de provincies Gelderland, Zeeland en Limburg.

Voor een uitgebreider beeld van de relevantie van de verschillende bedrijfstypen, met daarin ook aandacht voor de situatie per COROP-gebied (zie ook bijlage 3) wordt verwezen naar de factsheets per provincie.

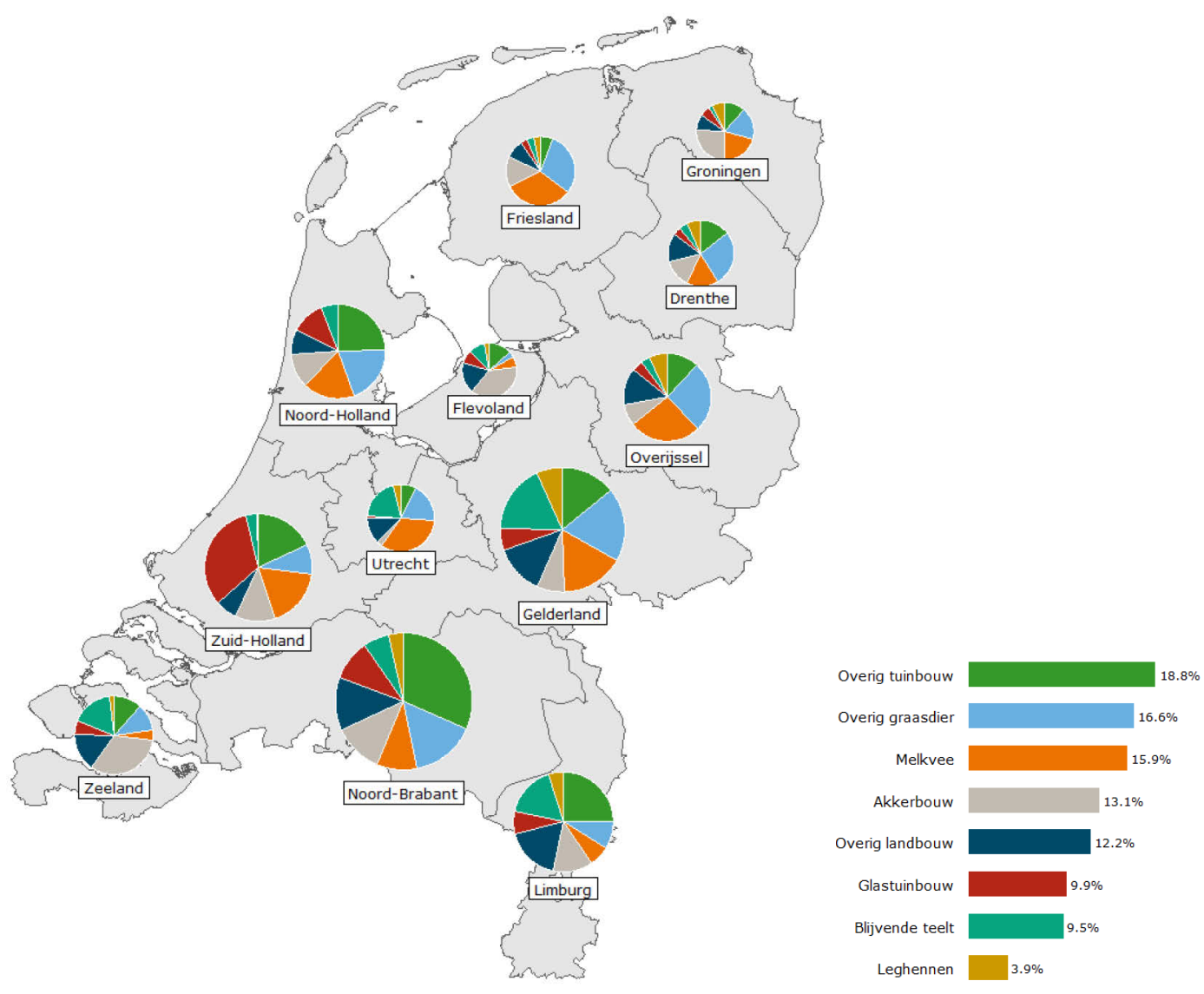

Figuur 3.5 Agrarische bedrijven met afzet via korte keten per provincie, ingedeeld naar aandeel bedrijfstype per provincie a), b), 2020

a) De omvang van een cirkel heeft een directe relatie met het aantal korteketenbedrijven;

b) percentage = aandeel bedrijfstype in totaal aantal korteketenbedrijven per provincie.

Bron: Landbouwtelling. 


\subsection{Omzet korte keten}

\subsubsection{Aandeel omzet korte keten in de bedrijfsomzet}

Alleen agrariërs die producten via een korte keten verkopen, hebben bij de opgave Landbouwtelling ingeschat hoeveel procent van hun bruto-opbrengsten (omzet) via een korte keten wordt gerealiseerd. Ze hebben daarbij kunnen kiezen tussen de volgende vier klassen: kleiner dan 10\%, 10-30\%, $30-50 \%$, en meer dan $50 \%$.

Opbrengst korte keten $\bullet<10 \% \bullet 10-30 \% \bullet 30-50 \% \bullet \geq 50 \%$

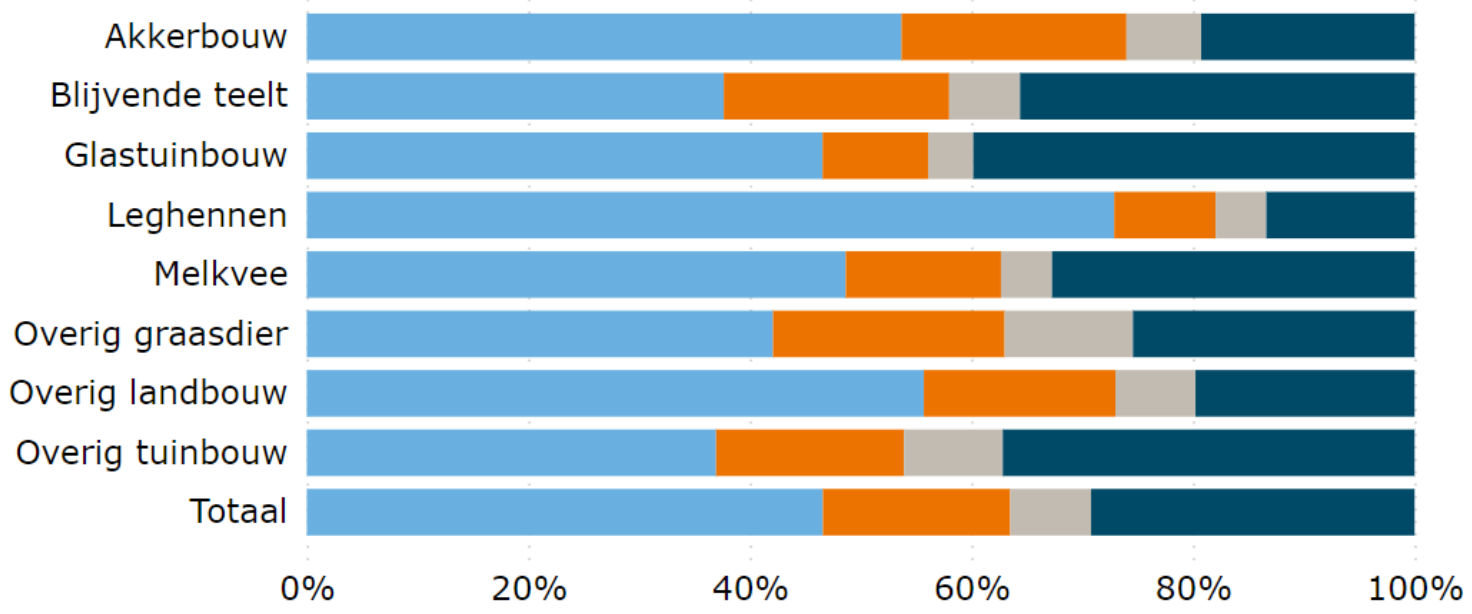

Figuur 3.6 Agrarische bedrijven (met afzet via korte ketens) naar percentage van de omzet dat via een korte keten wordt verkregen, ingedeeld naar bedrijfstype, 2020

Bron: Landbouwtelling.

Bijna de helft (47\%) van de korteketenbedrijven in Nederland geeft aan dat de opbrengst via afzet producten in korte ketens minder dan $10 \%$ van de totale opbrengst is (figuur 3.6). We zien dit hoge aandeel op bijna alle bedrijfstypen terug, wel in mindere mate binnen de groepen blijvende teelt en overig tuinbouw, en juist in sterkere mate in de leghennenhouderij (consumptie-eieren). Hier staat tegenover dat bijna drie op de tien bedrijfshoofden (30\%) heeft aangegeven dat meer dan de helft van de omzet via korte ketens binnenkomt. Dit aandeel in de klasse $>50 \%$ ligt in de drie onderscheiden tuinbouwsectoren (glastuinbouw, overig tuinbouw en blijvende teelt) het hoogst, en wel in de range tussen 35 tot $40 \%$ (figuur 3.6). Het is opvallend dat slechts een kwart van de agrarische bedrijfshoofden de klassen $10-30 \%$ (17\%) en 30 tot 50\% (7\%) heeft ingevuld. Voor veel bedrijven is de afzet via korte keten 'iets er bij', voor anderen ook echt een strategische weg voor (meer) bedrijfsperspectief.

Ruim een derde van de bedrijfshoofden op de zeer kleine bedrijven geeft aan dat minder dan $10 \%$ van de opbrengsten via de korte keten wordt gerealiseerd (zie figuur B3.4). Dit aandeel neemt geleidelijk met de bedrijfsomvang toe: van 45 en $47 \%$ op respectievelijk de kleine en middelgrote bedrijven naar 56 en $57 \%$ op de grote en zeer grote bedrijven. Op veel van deze bedrijven is (en blijft) verkoop via een korte keten een nevenactiviteit. Ook ongeveer een derde van de bedrijfshoofden op de zeer kleine bedrijven haalt meer dan de helft van de opbrengsten uit afzet via een korte keten. De overige grootteklassen blijven hier slechts een 4 tot 8 procentpunten op achter.

Van de subgroep die rechtstreekse verkoop in de Landbouwtelling heeft opgegeven (5.127 bedrijven) heeft $60 \%$ van deze bedrijven een aandeel van minder dan $10 \%$ ingevuld, $19 \%$ de klasse $10-30 \%$, $8 \%$ de klasse $30-50 \%$, en $13 \%$ geeft aan meer dan de helft van de opbrengsten via een korte keten te realiseren. Kijken we naar de subgroep die verkoopt via 1 tussenschakel (3.833 bedrijven), dan liggen deze percentages duidelijk anders: $37 \%$ vult minder dan $10 \%$ in, gevolgd door $18 \%$ de klasse $10-30 \%$, 
$10 \%$ de klasse $30-50 \%$, en ruim een derde (34\%) realiseert meer dan de helft van de opbrengsten via een korte keten. Opgemerkt hierbij dat 2.107 van deze korteketenbedrijven zowel rechtstreeks als via 1 tussenschakel producten hebben afgezet, en in beide subgroepen vertegenwoordigd zijn.

\subsubsection{Ruimtelijke verdeling omzetdichtheid}

De bedrijven met afzet via korte keten bevinden zich verspreid over heel het land. Dit zien we terug in de provinciale factsheets. Kijken we naar de aanwezigheid van de korteketenbedrijven in Nederland en hun geschatte opbrengsten via afzet korte ketens, dan krijgen we een indruk van de regionale omzetdichtheid (figuur 3.7). We zien een sterke concentratie van de omzet korte ketens in de glastuinbouwcentra: in (vooral) het Westland, regio Pijnacker/Nootdorp, de Haarlemmermeer, NoordHolland Noord, Noordoostpolder en de regio Kampen. Glastuinbouwbedrijven staan relatief dicht op elkaar, mede door de geringere bedrijfsoppervlakten ten opzichte van de grondgebonden bedrijven (zoals de akkerbouw en melkveehouderij). Daarnaast genereren glastuinbouwbedrijven gemiddeld veel omzet, zeker ten opzichte van de gemiddelde omzet in andere land- en tuinbouwsectoren. Een ander aspect is dat er in de glastuinbouw, een sector met veel schaalvergroting, in toenemende mate een korte lijn is tussen grote telers zelf en de grootwinkelbedrijven/ retail, met name voor de commodity-producten.

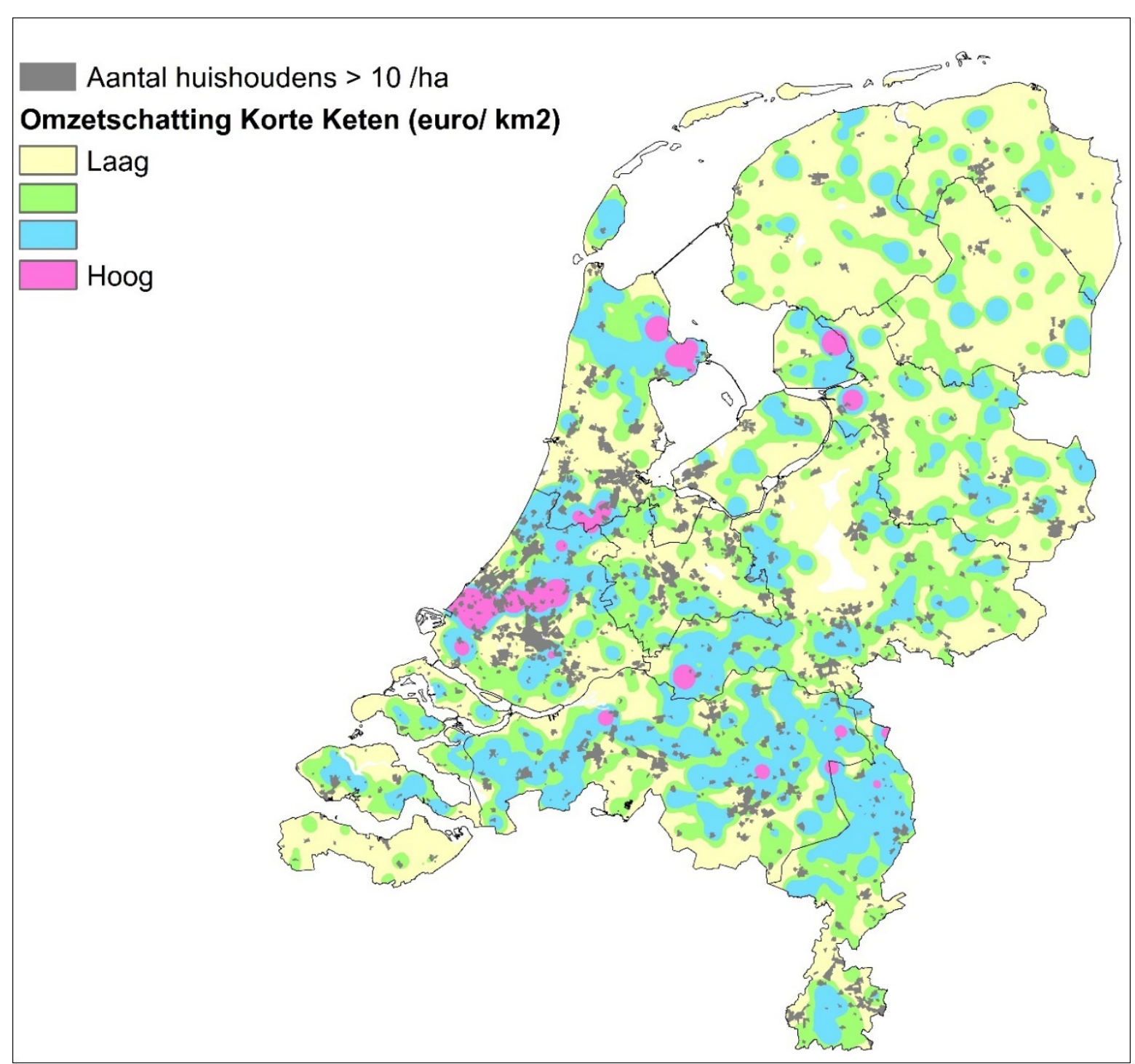

Figuur 3.7 Regionale spreiding omzet op agrarische bedrijven via korte ketens in Nederland, 2020 Toelichting: Dichtheidskaart: Kernel density, zoekstraal $5 \mathrm{~km}$ rond het bedrijf, output raster in hectare Bron: Landbouwtelling, bewerking Wageningen Economic Research. 
Ook relevant voor een hoge omzetdichtheid is de mate waarin bewerking van producten nodig is voordat het product aan de eindconsument verkocht kan worden. Denk daarbij aan tomaten en komkommers in de glastuinbouw en aan fruit in de Betuwe. Met name in de regio's met veel (grote) grondgebonden bedrijven (zoals akkerbouw, melkveehouderij) is de omzetdichtheid per km² lager. Dit heeft veel te maken met de gemiddelde bedrijfsgrootte in hectares van deze bedrijven, waardoor de omzet per ruimtelijke eenheid lager is. Ook is de bevolkingsdichtheid in deze regio's kleiner dan in veel andere regio's. De overheersing van grondgebonden landbouw zien we vooral terug in de Noordelijke provincies Zeeland en in Flevoland. Ook in Noord-Holland, Utrecht, Overijssel zijn regio's met veel grondgebonden bedrijven. In de provinciale factsheets staan de kaarten met de provinciale omzetdichtheid met een nadere toelichting.

\subsubsection{Totale omzet via korte ketens}

Op basis van de ingevulde percentages 'aandeel opbrengsten via korte ketens' en een berekening van de bruto-opbrengsten per bedrijf is een omzetschatting op bedrijfsniveau gemaakt. Voor de toegepaste methodiek wordt verwezen naar paragraaf 2.3 .

De totale opbrengsten uit afzet van voedings- en sierteeltproducten op agrarische bedrijven worden geschat op 1,359 miljard euro. Dit is gebaseerd op de bedrijven die vertegenwoordigd zijn in de Landbouwtelling 2020, en betreft de periode april 2019 t/m maart 2020 (in het vervolg wordt deze 12-maandelijkse periode als 2020 bestempeld).

Zoals in paragraaf 2.3 aangegeven zullen de cijfers over korte ketens op basis van de Landbouwtelling 2020 naar verwachting een onderschatting geven. In toenemende mate splitsen ondernemers hun bedrijven (als gevolg van bijvoorbeeld wetgeving, fiscale voordelen, of risicospreiding) in meerdere zelfstandige bedrijven met vaak een eigen rechtsvorm en boekhouding. Dit komt ook voor op agrarische bedrijven met multifunctionele activiteiten, waaronder ook rechtstreekse verkoop van agrarische producten.

Tabel 3.5 Schatting totale omzet via korte ketens op agrarische bedrijven, x 1 miljoen euro, 2020

\begin{tabular}{lc} 
Provincie & Opbrengst korte keten \\
Zuid-Holland & 356 \\
\hline Zeeland & 38 \\
\hline Utrecht & 31 \\
\hline Overijssel & 83 \\
\hline Noord-Holland & 177 \\
\hline Noord-Brabant & 212 \\
\hline Limburg & 115 \\
\hline Groningen & 29 \\
\hline Gelderland & 148 \\
\hline Friesland & 44 \\
\hline Flevoland & 84 \\
\hline Drenthe & 42 \\
\hline Totaal & 1.359 \\
\hline
\end{tabular}

Bron: Landbouwtelling, bewerking Wageningen Economic Research.

De hoogste opbrengst uit korte ketens wordt gerealiseerd in de provincie Zuid-Holland (356 miljoen euro). Ongeveer een $80 \%$ van de omzet is afkomstig uit de glastuinbouw, waar veel (zakelijke) afzet plaatsvindt via veelal een tussenschakel tussen producent en consument. In geen enkele andere provincie is het aandeel van een bedrijfstype zo sterk als in de glastuinbouw in Zuid-Holland. Een goede tweede is de provincie Noord-Brabant met 212 miljoen euro aan opbrengsten. De grootste bijdragen leveren hier de bedrijfstypen overig tuinbouw (ongeveer een derde deel) en de glastuinbouw (tussen de 20 en 25\%). Vervolgens wordt in Noord-Holland en in Gelderland de meeste omzet via korte ketens gerealiseerd. In de drie Noordelijke provincies, Utrecht en Zeeland liggen de geschatte opbrengstniveaus duidelijk lager, en lopen uiteen van 29 miljoen (Groningen) tot 44 miljoen 
(Friesland). De provincies Overijssel, Flevoland en Limburg vertegenwoordigen qua geschatte opbrengstwaarde de middengroep.

De verschillen per provincie hebben mede te maken met de mate van aanwezigheid van bedrijfstypen in de provincies. Met name de glastuinbouwregio's scoren een hoge omzetdichtheid (zie figuur 3.7 en de toelichting op deze figuur).

Bekijken we de aandelen van de hoofdbedrijfstypen in de totale omzet, dan scoort de glastuinbouw verreweg het hoogst met 44\% (595 miljoen euro). Dit heeft mede te maken met het feit dat veel bedrijven in de reguliere markt afzetten via 1 tussenschakel, en met de hoge gemiddelde bedrijfsopbrengsten van een glastuinbouwbedrijf. ${ }^{11}$

De glastuinbouw wordt gevolgd door de groep overig tuinbouw met bijna 210 miljoen euro. Hieronder vallen onder andere de opengrondgroentebedrijven, boomkwekerijen, champignonbedrijven en bloembollenbedrijven. Een goede derde is de melkveehouderij met een bedrag van 196 miljoen euro. Dit is ongeveer een derde deel van de opbrengsten gerealiseerd in de glastuinbouw. Een belangrijk onderdeel in de korte keten melkveehouderij is het zelfzuivelen van melk

Tabel 3.6 Schatting totale omzet via korte ketens op agrarische bedrijven, $x 1$ miljoen euro, 2020

\begin{tabular}{lr} 
Hoofidbedrifistype & Opbrengst korte keten \\
Akkerbouw & 55 \\
\hline Blijvende teelt & 595 \\
\hline Glastuinbouw & 79 \\
\hline Leghennen & 196 \\
\hline Melkvee & 90 \\
\hline Overig graasdier & 75 \\
\hline Overig landbouw & 209 \\
\hline Overig tuinbouw & 1.359 \\
\hline Totaal & \\
\hline
\end{tabular}

Bron: Landbouwtelling, bewerking Wageningen Economic Research.

De overige onderscheiden hoofdbedrijfstypen scoren totale opbrengsten tussen de 55 miljoen (akkerbouw) en 90 miljoen (overig graasdierhouderij). Gezien het relatief lage aantal leghennenbedrijven (548 bedrijven, waarvan 283 korteketenbedrijven) en blijvende teeltbedrijven ( 1.508 bedrijven, waarvan 683 een korte keten bedrijf) worden in deze beide groepen gemiddeld hoge opbrengsten per bedrijf via afzet korte ketens gerealiseerd.

\footnotetext{
${ }^{11}$ Het gemiddelde glastuinbouwbedrijf heeft in 2020 geraamde bedrijfsopbrengsten van 2.324 .000 euro. Ter vergelijking: voor het gemiddelde melkveebedrijf is dit 428.000 , voor het gemiddelde leghennenbedrijf 1.087 .000 en voor het gemiddelde fruitbedrijf 447.000 euro (Bron: Agrimatie.nl).
} 


\section{$4 \quad$ Suggesties voor stimulering korte ketens}

\subsection{Inleiding}

Via provinciale ambtenaren is gezocht naar gesprekspartners met een betrokkenheid bij korte ketens in hun provincie. Naast een reflectie op de gepresenteerde cijfers en ontwikkelingen met betrekking tot korte ketens in de betreffende provincie zijn genodigde personen ook gevraagd huidige belemmeringen en mogelijke handelingsperspectieven te benoemen. Dit is gedaan in eenmalige sessies zonder verdere voorbereiding. Onderstaand worden de belangrijkste punten uit deze sessies samengevat. Dit betreft alleen de input van de gesprekspartners.

In de Landbouwtelling is de volgende EU-definitie voor korte ketens aangehouden: Geen of maximaal één schakel (toeleveringsketenpartij) tussen producent (boer/tuinder) en consument. Rechtstreekse verkoop betreft de verkoop langs de weg, op de markt, via internet, via een eigen winkel en bezorging aan huis. Bij één schakel gaat het om directe leveringen aan retail, horeca $\&$ catering en markten. Het bestaan van verschillende definities kan ertoe hebben geleid dat er tijdens de Provinciale sessies verschillende interpretaties van de definitie als uitgangspunt zijn genomen door de genodigden.

\subsection{Aandacht voor (meervoudige) warde creatie}

Producenten zijn nog te veel bezig met de productie. Ze lijken de verkoop (zoals marketing) te onderschatten of moeten daarvoor (meer) gaan samenwerken. Er liggen meerdere kansen. Zo wordt in Zeeland onder andere horeca en recreatie benoemd als een geïnteresseerde afnemer. Maar wie neemt de eerste stap om een breed aanbod te organiseren en wie is risicodrager?

Ondernemers zouden meer kennis van de afzetmarkt (wie, waar, welke eisen) kunnen vergaren, aldus aanwezigen in diverse Provinciale sessies (december 2020-februari 2021). Dit in combinatie met het actief ontwikkelen van de eigen vaardigheden. Overheid kan hierbij ondersteunen met een tool box met keuzes.

Meervoudige waardecreatie biedt kansen waar de korte keten onderdeel van kan zijn. Je krijgt dan ook te maken met andere betalende partijen. Welke kansen bieden bijvoorbeeld kringlooplandbouw/circulaire economie of landschapsbeheer? De thema's bodem - voedselkwaliteit biodiversiteit - water en klimaat raken ook aan de (korte) keten. Overheden kunnen helpen om tot nieuwe initiatieven te komen. Bijvoorbeeld door de inzet van kennisvouchers. Dat verlaagt mogelijk de drempel bij het inwinnen van advies.

Niet moet worden vergeten dat producenten vaak 'vastzitten' in hun bestaande keten, Er moet bijvoorbeeld minimaal $x \%$ omzet aan de coöperatie worden geleverd of de eis is maximaal $10.000 \mathrm{~kg}$ melk per jaar zelf verzuivelen.

\subsection{Logistiek en organisatie}

Afnemers vragen meer dan alleen een onderscheidend product. Het zit ook in versheid en leveringszekerheid. Partijen willen erop aan kunnen dat je altijd kan leveren. Daarmee komen we op het aspect dat over alle provincies heen het meest wordt benoemd: logistiek. Dit is nog steeds een grote uitdaging voor veel korteketeninitiatieven. Wellicht nog niet eens zo zeer de beschikbaarheid 
van logistieke lijnen en middelen. Het is veel meer de wijze waarop dit binnen de korte keten logisch en efficiënt georganiseerd kan worden.

Logistieke problemen spelen uiteraard niet of nauwelijks bij boerderijverkoop, maar vooral bij verkoop op andere plaatsen dan het boerderijbedrijf en nemen toe bij opschaling (hoge kosten gevraagde fijnmazigheid van distributie, koeling in overeenstemming met voedselveiligheidsnormen, verwerkingscapaciteit).

Coördinatie en samenwerking is nodig bij opschaling/professionalisering, waarbij overheid kan ondersteunen. Maar ondernemers zullen dit in de eerste plaats vooral met elkaar moeten regelen. Krachten moeten bundelen, elkaar vertrouwen en transparante spelregels moeten toepassen.

Het is best lastig om je logistiek uit handen te geven. Zeker als je gewend bent om als ondernemer zelf je producten rond te rijden en uit eerste hand positieve en negatieve feedback krijgt welke bruikbaar is voor de verdere ontwikkeling van je product en/of service. Toch ligt hier veelal de uitdaging omdat veel afnemers een breder productpakket vragen dan wat de korteketenproducent zelf kan leveren. Dus hoe krijg je een bestelling het beste gebundeld, zodat het op 1 plek bewerkt of verwerkt wordt? Het helpt niet mee als je geen of een beperkt overzicht hebt van het aanbod in jouw regio. Het ontbreken hieraan - en daarmee het vinden van het juiste moment om op te schalen lijken nog wat complexer dan de vraag of je je logistiek wel of niet moet uitbesteden

\subsection{Regelgeving en hoge kosten}

Doordat de kosten ver voor de baten uit gaan in een nichesituatie, en de ondernemer in het begin nog geen structurele inkomsten kan genereren maar wel toegevoegde waarde ziet, is het inzetten van subsidie voor opstartende korteketenondernemers geen overbodige luxe. De toegankelijkheid voor deze subsidies zou wel beter kunnen. Procedures zijn vaak omslachtig en de boer vindt niet altijd de weg naar deze subsidies. Nieuwe initiatieven moeten een aanloopperiode (minstens 1 à 2 jaar) financieel kunnen overbruggen. Dat vraagt ook wat van ondernemers. Zij moeten echt bereid zijn in de korte keten te investeren.

Relatief hoge kosten worden er ook gemaakt voor keuring en monsterafname (met name voor kleine ambachtelijke bedrijven). Hier zou iets aan gedaan kunnen worden voor korteketenbedrijven. Een mooi voorbeeld is SKAL welke ook lagere prijzen heeft voor kleine producenten.

En wat kan er gedaan worden aan regelgeving? Is het bijvoorbeeld mogelijk om bestemmingsplannen aan te passen? Creëer daarmee lokale verkooppunten. Ook al is er geen retail bestemming. Biedt meer mogelijkheden voor boerderijwinkels. Anderzijds kunnen ondernemers ook met wat creativiteit afhaalpunten faciliteren (zonder financiële transacties), waarvoor de bereikbaarheid wordt vergroot.

\subsection{Kennisontwikkeling}

Kennisontwikkeling is van belang om de gehele korte keten (van producent tot consument) verder te ontwikkelen. Aanwezigen in diverse provinciale sessies benoemen hierbij onder meer dat:

- Er is een rol voor het onderwijs. Zo kan er samen met het onderwijs worden gekeken welke markt er gecreëerd kan worden met een nieuw systeem en hoe dit eruit komt te zien.

- Richt je op educatie. Waar komt je voeding vandaan? Verwerk dit ook in lesprogramma's voor kinderen.

- Overheden kunnen helpen door kennisvoorbeelden te delen, zodat daarmee succes en faalfactoren worden gedeeld. Hiermee kan vertrouwen worden gecreëerd.

- Voor banken, kennisinstellingen, ketenpartijen en burgerinitiatieven wordt een actieve rol gezien om korte keten initiatieven verder te ondersteunen. Er is echter te weinig ervaring met kengetallen voor een ander verdienmodel van boeren bij banken. Dat resulteert dan vaak in financiering die beschikbaar is. Meer kennis kan hierbij behulpzaam zijn. 
- Als een boer werkt aan een duurzaam product en de consument gooit het vervolgens weg, is er nog niks bereikt. Sterker nog, dan zijn we niet alleen heel veel voedsel, maar ook heel veel energie onnodig kwijt. Korte ketens kunnen een bijdrage leveren om de voedselverspilling terug te dringen door op maat aan te leveren of door specifieke producten te ontwikkelen. Daarvoor moet men wel kennis hebben van de eindgebruiker. Neem de consument ook hierin mee.

\subsection{Stimuleren van de vraag}

In een aantal provinciale sessies is ook nadrukkelijk de verdere ontwikkeling van de marktkant (pull) benoemd als belangrijk aandachtspunt om korte ketens verder te ontwikkelen. Hierbij is mogelijk ook een rol voor de overheid weggelegd. Hoewel dit onderzoek gericht is op de productiekant van de korte keten worden hieronder een aantal van de benoemde punten opgesomd. Er zijn veel overeenkomsten met aanbevelingen welke ook zijn terug te vinden in het rapport Korteketenproducten in Nederland (Tacken et al., februari 2021).

Het stimuleren van de vraag naar korteketenproducten bij consumenten kan via verschillende invalshoeken gebeuren:

- De genodigden geven aan dat de overheid en andere partijen vooral een taak hebben in het in beweging krijgen van de consument (en dat begint al bij de jeugd via onderwijs) welke veelal gericht is op gemaksvoedsel. Probeer actief de vraag te stimuleren. Hoe krijg je meer Nederlands (of regionaal) voedsel in de supermarkt? Beleid kan meer worden gericht op de omslag naar gezonde voeding als basis.

- Een regionaal product moet een gegarandeerde herkomst en duurzame productiewijze krijgen en niet vogelvrij op een etiket gezet worden.

- Campagne c.q. meer aandacht voor eten uit het seizoen, zodat een groter aandeel van dichtbij kan komen.

- True Pricing doorvoeren. De 'duurzaamheid' van korte ketens is vaak nog onduidelijk. Als producten in supermarkten de echte prijs zouden hebben worden korteketenproducten wellicht ook interessanter (ervan uitgaande dat de korte keten producten ook meerdere duurzaamheidaspecten ook echt beter scoren) qua prijs voor de consument.

- De overheden kunnen zelf meer een voorbeeldrol (voor bedrijfsleven) vervullen met de eigen duurzamere inkoop. Door provincies en LNV wordt hier al aan gewerkt door middel van de Greendeal Catering.

\subsection{Gezamenlijke verantwoordelijkheid}

Gezamenlijke verantwoordelijkheid in de korte keten is een punt dat veel werd benoemd in de Provinciale sessies. Zowel boeren, overheden en ketenpartijen moeten verantwoordelijkheid nemen om gezamenlijk succes te hebben. Samenwerking is daarbij uiterst belangrijk. Met clustervorming zou de korte keten een succes kunnen worden. Je hebt hierbij onder andere iemand nodig in die regio die kennis van vraag en aanbod bij elkaar brengt. De stakeholders in deze sessie geven aan dat overheden (hierbij is specifiek de provincie genoemd) kunnen helpen bij bijvoorbeeld het verstevigen van het netwerk, het aanstellen van bijvoorbeeld een voedselmakelaar of programma's door te zetten en uit te bereiden. Er zijn al mooie initiatieven gaande (zie box). 
- FoodUp Brabant (onderdeel provincie) werkt aan robuust voedselsysteem (gezond, eerlijk en lekker). Voedsel dat goed is voor mens, dier en omgeving én een eerlijke prijs oplevert voor de boer. Speerpunten: verbinden van boeren en burgers, nieuwe verdienmodellen, onderwijs en jongeren.

- Het innovatieve Limburgse programma LOF, waarbij het doel is om zoveel mogelijk lokaal, gezond geproduceerd voedsel op Limburgse werkvloer te krijgen, in onderwijs, sport en horeca. Daarbij krijgt iedere speler in de keten een eerlijke prijs betaald en worden duurzame investeringen beloond.

- De stichting Voedsel Verbindt heeft ten doel: het verwezenlijken van een robuust, duurzaam en gezond regionaal voedselsysteem ten behoeve van een leefbare metropoolregio Amsterdam en omliggende agrarische gebieden.

- DrentsGoed streekproducten werkt al 20 jaar samen met lokale boeren. Bij Drents goed zie je dat boeren elkaar niet beconcurreren en goed samenwerken. Nu samenwerking met DubbelDrents.

- Het is van groot belang om inzichtelijk te maken voor de consument waar je lokale producten kunt krijgen. Daarvoor zijn al meerdere initiatieven ontwikkeld zoals www.eetbaarfriesland.nl/Friese voedselbeweging 


\section{$5 \quad$ Slotbeschouwing}

\section{Belangrijkste resultaten}

De monitor korte ketens 2020 laat zien dat het aantal land- en tuinbouwbedrijven dat voedsel- of sierteeltproducten rechtstreeks of via 1 tussenschakel afzet bij de consument in de periode 1 april 2017 tot 1 april 2020 met meer dan een kwart ( +1.510 bedrijven) is gestegen tot 7.234 bedrijven. Dit is $13,7 \%$ van het totaal aantal bedrijven gepresenteerd in de database Landbouwtelling 2020. In 2017 was dit aandeel 10,5\%. De groei in het aantal korteketenbedrijven zien we terug in alle provincies in meer of mindere mate terug. In Limburg ligt het aandeel korte ketens het hoogst met $20 \%$.

Op $45 \%$ van de korteketenbedrijven zijn de opbrengsten minder dan $10 \%$ van de totale bedrijfsopbrengsten. Hier staat tegenover dat een kwart van de bedrijven aan geeft dat dit meer dan de helft is, en dus in grote mate gespecialiseerd is in afzet via korte ketens. In totaal wordt in de primaire land- en tuinbouw met de afzet via korte ketens 1,36 miljard euro aan opbrengsten gerealiseerd. Dit is rond de $5 \%$ van de agrarische productiewaarde in 2020. De hoogste omzet via korte ketens zien we terug in de provincie Zuid-Holland (356 miljoen euro, waarvan $80 \%$ in de glastuinbouw), gevolgd door Noord-Brabant, Noord-Holland en Gelderland. De grootste omzet via korte ketens vindt plaats in de glastuinbouw (bijna 600 miljoen), op afstand gevolgd door de groep overig tuinbouw (bijna 210 miljoen) en de melkveehouderij (196 miljoen) en de groep overig tuinbouw. Relatief veel korte keten omzet vindt plaats binnen kleinere bedrijfstypen met producten waarbij weinig bewerking nodig is tussen productie en consumptie. Dit geldt vooral voor de leghennenhouderij en fruitteelt.

\section{Opvallende resultaten}

- Het aandeel korteketenbedrijven in het totaal aantal bedrijven is het hoogst in de groep zeer grote bedrijven: bijna een op de vijf zeer grote bedrijven houdt zich bezig met korte keten verkoop. Dit kan mede te maken hebben met ondernemerschap en het realiseren van kansen bij de afzet van producten (met daarbij het hebben van een financiële buffer om te investeren in nieuwe strategieën). Ook is het zo dat zeer grote bedrijven (met name in de glastuinbouw) meer bewerkingsslagen van producten zelf organiseren en daardoor in toenemende mate via maximaal 1 tussenschakel de consument bereiken.

- Het aandeel korteketenbedrijven is hoog op bedrijven met multifunctionele activiteiten (nietagrarische activiteiten), en dan met name op bedrijven met educatiediensten, zorgverlening en dagof verblijfsrecreatie. Op deze bedrijven komen relatief veel (potentiële) consumenten op het erf die in toenemende mate vertrouwd raken met het productieproces van het bedrijf, of bij de lunch producten van het bedrijf of uit de regio eten.

- Afzet via een korte keten vindt op de biologische bedrijven op meer dan een op de drie bedrijven plaats. Op de bedrijven met gangbare productiesystemen is dit aandeel veel lager (13\%).

- Het aandeel korteketenbedrijven ligt het hoogst op bedrijven met een bedrijfshoofd tot 40 jaar $(17,3 \%)$. Ook in de provinciale sessies komt naar voren dat relatief veel jongeren inspringen op nieuwe kansen via afzet eigen producten in korte ketens. Op bedrijven met een bedrijfshoofd ouder dan 50 jaar zien we tussen de groepen met of zonder potentiële bedrijfsopvolger weinig verschil in het aandeel korteketenbedrijven.

- In provincies met veel korteketenbedrijven, zoals Noord-Brabant en Gelderland, zien we dat korteketenbedrijven op veel bedrijfstypen voor komen. Dit biedt ondernemers mogelijkheden breder samengestelde pakketten aan korte keten producten uit de regio aan te bieden. Consumenten vinden het in toenemende mate belangrijk dat een breed assortiment aan regionale producten op 1 locatie wordt aangeboden. Dit geldt zowel voor lokale burgers als - zij het in mindere mate - voor toeristen. In andere provincies (met name die met veel grondgebonden landbouw) zien we juist dat de korteketenbedrijven zich vooral binnen enkele bedrijfstypen bevinden. In deze regio's is het lastiger een breed assortiment aan regionale producten aan te bieden.

- De hoeveelheid bedrijven en de regionale spreiding van korteketenbedrijven wordt vooral bepaald door de aanwezigheid van bedrijfstypen, welke veelal voortkomt uit de aanwezige grondsoort (veen, 
klei, zavel, zand) in een gebied. Een ander bepalende factor is het aantal bewerkingsslagen voordat het product kan worden geconsumeerd. Ook de bevolkingsdichtheid, de aanwezigheid van recreatie (maar ook de aanwezigheid en inkoopbeleid van supermarkten en catering, zie Tacken et al., 2021) spelen aan de vraagkant een belangrijke rol. Daarnaast komen er in toenemende mate initiatieven (rondom steden) om tot meer regionale voedselvoorzieningssystemen te komen.

\section{Definitie en databron Landbouwtelling}

- De databron Landbouwtelling geeft een compleet beeld van bedrijven die als agrarisch bedrijf ingeschreven staan in de registers van de Kamer van Koophandel. Al deze bedrijven zijn verplicht de vragen in de Landbouwtelling in te vullen. Op een klein deel van de bedrijven, die activiteiten op het bedrijf splitsen in twee of meer zelfstandige bedrijven met eigen rechtsvormen, kunnen nietagrarische activiteiten, waaronder bijvoorbeeld ook een boerderijwinkel, daardoor niet volledig in beeld komen. Het is aan te bevelen nader onderzoek te verrichten naar de omvang van de niet door de Landbouwtelling gepresenteerde omzet via korte ketens.

- De resultaten van deze meting zijn gebaseerd op beschikbare data uit de Landbouwtelling. De definitie gericht op het aantal schakels tussen producent en consument heeft als voordeel dat het meetbaar is. Gezien de relatief korte omschrijving die bij deze vraag in de Landbouwtelling wordt gegeven kan het voor een deel van de ondernemers (mede afhankelijk van het type product) lastig interpreteerbaar zijn wanneer er sprake is van 1 of meer tussenschakels.

- Het voordeel van de databron Landbouwtelling is dat periodiek alle bedrijven in deze telling gegevens over korte ketens invullen, waardoor regelmatig een actueel beeld en de ontwikkeling van korte ketens kan worden gegeven.

- De Landbouwtelling 2020 geeft de situatie weer per 1 april 2020. Dit betekent dat de effecten van COVID-19 op de afzet via korte ketens niet of nauwelijks in deze meting zit. Met name na 1 april 2020 stond het kopen en consumeren van lokaal geproduceerde goederen volop in de belangstelling en hebben consumenten in toenemende mate producten in de regio gekocht (onder andere via rechtstreeks kopen bij de boer en tuinder). In een volgende meting korte ketens (of via nader onderzoek) kan worden vastgesteld of deze geconstateerde opleving blijvend is en zich verder zal ontwikkelen.

- Bij de totstandkoming van de Nationale Samenwerking rond korte ketens hebben de provincies, het ministerie van LNV en de TKK gezamenlijk besloten uit te gaan van de bredere EU-definitie van korte ketens: een toeleveringsketen met een beperkt aantal marktdeelnemers die zich inzetten voor samenwerking, lokale economische ontwikkeling en nauwe geografische en sociale betrekkingen tussen voedselproducenten, -verwerkers en consumenten.

- Een ander aandachtspunt is dat de visserij niet vertegenwoordigd is in de Landbouwtelling. Ook in deze sector vindt afzet plaats via korte ketens. Aanbeveling is te onderzoeken of deze voedingstak in een volgende meting kan worden meegenomen

\section{Overige punten}

- Nader onderzoek is gewenst naar het effect van afzet via korte ketens op het economisch perspectief van boer en tuinder: in hoeverre leidt deze afzet bijvoorbeeld tot structureel hogere prijzen en daarmee hogere inkomens?) En heeft meer afzet via korte ketens impact op de vitaliteit van het platteland? Eveneens is onderzoek naar de effecten van een toenemende verbinding tussen boer en burger interessant: ontstaat er door meer onderling contact en inkijk van burgers in productieprocessen meer begrip voor elkaars belangen?

- Zoals uit hoofdstuk 4 naar voren komt is meer onderlinge samenwerking tussen ondernemers op korteketenbedrijven (en ook met verwerkers en consumenten) een belangrijk aandachtspunt. Dit mede ook vanuit logistiek oogpunt. Welke stimulerende rol kunnen overheden en ketenpartijen hierbij spelen?

- Regelmatig wordt de vraag gesteld in welke mate productie met afzet via korte ketens bijdraagt aan een duurzamere land- en tuinbouwsector. Belangrijk daarbij is een goed afgebakende (meetbare) definitie van duurzaamheid. Meerdere aspecten spelen hierbij een rol, zoals uitstoot van $\mathrm{CO}_{2}$ en $\mathrm{NH}_{3}$, fijnstof, bodemkwaliteit, biodiversiteit, landschap, maar ook economische, sociale en logistieke aspecten.

- Een resultaat van deze nulmeting is dat het aandeel korteketenbedrijven in de duurzamer producerende biologische landbouw veel hoger ligt dan in de gangbare landbouw. Het kan 
interessant zijn voor gangbare bedrijven, die streven naar een verdere verduurzaming van het productieproces, te onderzoeken in hoeverre afzet via korte ketens daarbij een rol kan spelen.

- Meer inzicht in de effecten van provinciaal beleid bij het stimuleren van korte ketens. Heeft stimulering en facilitering door provinciaal beleid geleid tot meer ontwikkeling van korte ketens? Zien we verschillen tussen provincies?

- Meer inzicht in de verschillen tussen de groep korte keten bedrijven die rechtstreek afzet en de groep waarbij de afzet via 1 tussenschakel de consument bereikt. Vooral in de groep bedrijven met verkoop via 1 tussenschakel zitten grote primaire bedrijven (zoals in de glastuinbouw) die zelf bewerkingsactiviteiten voor hun rekening nemen. In dat geval komen de sociale en regionale componenten, verwerkt in de brede definitie van korte keten die LNV, provincies en TKK hanteren, minder nadrukkelijk naar voren.

- Provincies /regio's kunnen beleid gericht op stimulering korte ketens implementeren in:

- Toeristen strategie /visie

- Verdienvermogen boeren en toekomstperspectief boeren

- Vitaliteitsagenda platteland

- Aanbieden van een breed regionaal voedselpakket in bepaalde regio's (denk aan regio's in Gelderland en Noord-Brabant met veel regionale producten) aan toeristen, burgers, maar bijvoorbeeld ook aan zorginstellingen, gevangenissen etc.

Concluderend lijkt een gezamenlijke aanpak van Rijk, provincies, sector en de TKK belangrijk om afzet van agrarische producten via korte ketens verder te ontwikkelen. Vanuit de praktijk liggen de aandachtspunten vooral op meer onderlinge samenwerking tussen ondernemers, op logistiek en organisatie, het wegnemen van knelpunten in regelgeving, op kennisontwikkeling- en overdracht naar ondernemers, maar ook op het stimuleren van de vraag naar korte keten producten. Ook is er meer inzicht nodig in de directe effecten en impact van korte ketens op het economisch perspectief van bedrijven, op de verbinding boer-burger, de vitaliteit van plattelandsregio's, en de duurzaamheid van agrarische ketens (gedurende de productie, toelevering, verwerking en distributie). Een onderzoekagenda gericht op het stimuleren van korte ketens kan hierbij een belangrijke sturende en coördinerende rol spelen. 


\section{Literatuur en websites}

Agrimatie.nl

Https://www.cbs.nl/nl-nl/onze-diensten/methoden/onderzoeksomschrijvingen/korte-

onderzoeksbeschrijvingen/landbouwtelling

Meulen, H. van der, J. Jager, D. de Jong, R. Stokkers, G. Venema en M. Vijn (2019). Kijk op multifunctionele landbouw: omzet 2007-2018 (Ser. Wageningen Economic Research rapport, 2019-054). Wageningen Economic Research. https://doi.org/10.18174/476198.

Rabobank Food \& Agribusiness (2020). Blauwdruk Korte Ketens

Tacken, G., J. Galama, P. Jaspers, V. Immink en L. Aramyan (2021). Korteketenproducten in Nederland; Zijn horeca, catering en supermarkten geïnteresseerd in producten uit de regio. Wageningen, Wageningen Economic Research, Rapport 2021-013.

Van der Schans, J.W. en D. van Wonderen (2019). Korte ketens in Gelderland (No. 2019-072). Wageningen Economic Research.

Wisman, A. (2020). NSO-typering agrarische bedrijven 2020; Normen en uitgangspunten bij typering agrarische bedrijven in Nederland. Wageningen, Wageningen Economic Research, Nota 2021-012. 


\section{Bijlage 1 Begrippenlijst}

\section{Landbouwtelling}

De Landbouwtelling is een structuurenquête die onderdeel uitmaakt van de gecombineerde data inwinning (GDI) die door de Rijksdienst voor Ondernemend Nederland (RVO) wordt uitgevoerd. Het CBS beschrijft met de ingewonnen gegevens de structuur (onder andere bedrijven, veestapel en gewassen) van agrarische bedrijven in Nederland en stelt informatie beschikbaar aan onderzoek en beleid. De doelpopulatie omvat agrarische bedrijven met meer dan 3.000 euro Standaardopbrengst (SO).

Primaire Land- en tuinbouwbouwbedrijven: Bedrijven die land- en tuinbouwproducten voor de markt voortbrengen, met hoofdvestiging in Nederland, en een economische omvang $>=3.000$ euro so (Standaardopbrengst).

\section{Vraagstelling korte ketens in de Landbouwtelling}

- Verkoopt u rechtstreeks producten aan consumenten? Het gaat om producten die op uw bedrijf zijn geproduceerd of verwerkt.

In de toelichting staat: verkoop langs de weg, op de markt, via internet, via een eigen winkel, bezorging aan huis

- Verkoopt u via 1 tussenschakel producten aan consumenten? Het gaat om producten die op uw bedrijf zijn geproduceerd of verwerkt.

In de toelichting staat; Onder andere directe leveringen aan (streek)winkels, horecagelegenheden en markten. Het gaat hier niet om het gezamenlijk afzetten aan groothandels of veilingen.

Let op: 'rechtstreekse verkoop aan de consument' en 'verkoop via 1 tussenschakel' tellen niet op tot 'korteketenverkopen' omdat een bedrijf één of beide activiteiten kan hebben; deze tellen slechts $1 \times$ mee als verkoop aan huis.

- Aandeel opbrengst afzet via korte keten in totale omzet

Alleen bedrijven die producten afzetten rechtstreeks of via 1 tussenschakel aan de consument (in deze monitor korteketenbedrijven genoemd) hebben in de Landbouwtelling de volgende vraag ingevuld:

Hoeveel procent (\%) van de totale bruto-opbrengst van uw bedrijf (inclusief subsidies) ontvangt u uit de verkoop aan consumenten, rechtstreeks of via 1 tussenschakel?

De volgende klassen kunnen worden ingevuld:

Opbrengst minder dan 10\%;

Opbrengst 10-30\%;

Opbrengst 30-50\%;

Opbrengst meer dan $50 \%$

\section{Standaardopbrengst (SO)}

De SO-norm is een gestandaardiseerde opbrengst (in euro) per ha of per dier die met een gewas of diercategorie gemiddeld op jaarbasis wordt behaald. Opbrengsten uit bedrijfstoeslagen en subsidies zijn niet in de norm meegenomen. Voor biologische productiemethoden worden dezelfde SO-normen gehanteerd als voor gangbare productiemethoden. De SO-norm wordt vastgesteld voor elk agrarisch product dat in de Landbouwtelling wordt gevraagd. De SO-normen zijn gebaseerd op genormaliseerde vijfjaargemiddelde opbrengsten (zie verder Wisman, 2021)

\section{Standaardverdiencapaciteit (SVC)}

De bedrijfsomvang in SO is over bedrijfstypen heen niet altijd even sterk gerelateerd met de arbeidsinzet of met de toegevoegde waarde. Op een akkerbouwbedrijf blijft bijvoorbeeld van 100.000 euro opbrengsten gemiddeld veel meer toegevoegde waarde over dan op een vleesvarkensbedrijf (respectievelijk ongeveer 33\% en circa 11\%), doordat in de varkenshouderij de 
toegerekende kosten (vooral veevoer) relatief hoog zijn. Met het kengetal standaardverdiencapaciteit (SVC) wordt daarmee rekening gehouden. Voor vergelijking van bedrijven uit verschillende sectoren op basis van schaalgrootte naar arbeidsbehoefte of toegevoegde waarde is de omvang in SVC beter te gebruiken dan de omvang in SO, dat wordt hieronder uitgelegd.

De SVC geeft een beeld van de vergoeding voor de inzet van arbeid en kapitaal die een bedrijf op basis van standaarden gemiddeld in een jaar behaalt met de agrarische productie, los van wie de arbeid of het kapitaal heeft geleverd. Opbrengsten uit bedrijfstoeslagen, betaalrechten, subsidies of multifunctionele landbouw zijn daarin dan niet meegenomen. De werkelijk gerealiseerde toegevoegde waarde van een bedrijf zal vrijwel nooit gelijk zijn aan de berekende SVC, vanwege verschillen in prijsvorming, technisch resultaat, productbewerking, subsidies, intern verkeer of opbrengsten uit multifunctionele activiteiten in vergelijking tot de gebruikte standaarden.

De SVC van een bedrijf wordt berekend door de Standaardopbrengst van vastgestelde SO-groepen te vermenigvuldigen met de Verdiencoëfficiënt van die SO-groep. Die coëfficiënt geeft aan welk deel van de Standaardopbrengst (SO) gemiddeld als vergoeding voor arbeid en kapitaal resteert voor die specifieke groep van agrarische producten (SO-groep). In 2020 is de SVC geactualiseerd (prijsniveau 2017).

Voor gebruik van de SVC zijn 'standaardgrootteklassen' vastgesteld om bedrijven in te delen. De gehanteerde grenzen van die klassen zijn gebaseerd op de gemiddelde gerealiseerde verhouding van de SVC per arbeidskracht (zoals uit de Landbouwtelling naar voren komt) en zijn dus gebaseerd op een gemiddeld-efficiënte arbeidsinzet. De werkelijke arbeidsinzet van een individueel agrarisch bedrijf hangt onder andere af van de efficiëntie van de arbeidsinzet, de mate van mechanisering en de multifunctionele activiteiten. Omdat de werkelijke toegevoegde waarde van een bedrijf af kan wijken van de norm is het mogelijk dat de omschrijving bij de grootteklasse niet van toepassing is op elk individueel bedrijf. De uitkomsten moeten dan ook vooral als een (globale) richtlijn worden gezien.

Er zijn 5 klassen gedefinieerd op basis van het bedrag aan SVC:

1. <25.000 euro: zeer kleine bedrijven

Deze bedrijven vragen voor de agrarische activiteit volgens de in gebruik zijnde standaarden een arbeidsinzet van maximaal 0,75 arbeidsjaareenheden (aje), tenzij de arbeid duidelijk minder efficiënt of tegen een lagere vergoeding dan gemiddeld wordt ingezet.

2. 25.000-60.000 euro: kleine bedrijven

Deze bedrijven vragen voor de agrarische activiteit volgens de in gebruik zijnde standaarden een arbeidsinzet van 0,75 tot maximaal 1,5 aje, afhankelijk van de mate van automatisering en de efficiëntie waarmee de arbeid kan worden ingezet.

3. 60.000-100.000 euro: middelgrote bedrijven

Deze bedrijven zijn van dusdanige omvang dat voor 1,5 tot 2,5 aje een gemiddelde vergoeding (toegevoegde waarde) kan worden gerealiseerd.

4. 100.000-250.000 euro: grote bedrijven

Deze bedrijven zijn van dusdanige omvang dat voor 2,5 tot 5 aje een gemiddelde toegevoegde waarde kan worden gerealiseerd.

5. $>=250.000$ euro: zeer grote bedrijven

Deze bedrijven kunnen aan meer dan 5 aje arbeid bieden tegen een gemiddelde vergoeding.

De indeling en naamgeving van de grootteklassen is mede gekozen vanuit meerdere vragen over de volwaardigheid van bedrijven, en is gebaseerd op de verdeling van bedrijven in de totale populatie van land- en tuinbouwbedrijven. Voor 2019 geldt bijvoorbeeld dat van de 53.233 bedrijven ongeveer $35 \%$ als zeer klein moet worden beschouwd en ongeveer $9 \%$ als zeer groot. Tussen de agrarische bedrijfstypen bestaan grote verschillen in verdeling van bedrijven over de grootteklassen. Van de akkerbouwbedrijven valt in 2019 de helft in de groep zeer kleine bedrijven en minder dan $5 \%$ bij de zeer grote bedrijven, terwijl dat bij de glastuinbouwbedrijven juist andersom is. Ook in vergelijking met bedrijven uit andere (niet-agrarische) sectoren kan het zijn dat een bedrijf met 6 werknemers niet als 'zeer groot' wordt beoordeeld, maar bijvoorbeeld als 'klein' wordt gezien. Zie voor meer informatie over de SVC: Wisman, 2021. 


\section{Bijlage 2 Typering bedrijven}

In tabel B2.1 wordt het volgende overzicht gegeven:

- Onder welk NSO-hoofdtype (kolom 1) de verschillende NSO-bedrijfstypen (kolom 2) vallen.

- Welke NSO-bedrijfstypen (kolom 2) onder de in dit onderzoek (monitor korte ketens) gehanteerde hoofdtypen (kolom 3) vallen.

Tabel B2.1 Relatie tussen NSO-bedrijfstypen en hoofdtypen in de monitor korte ketens

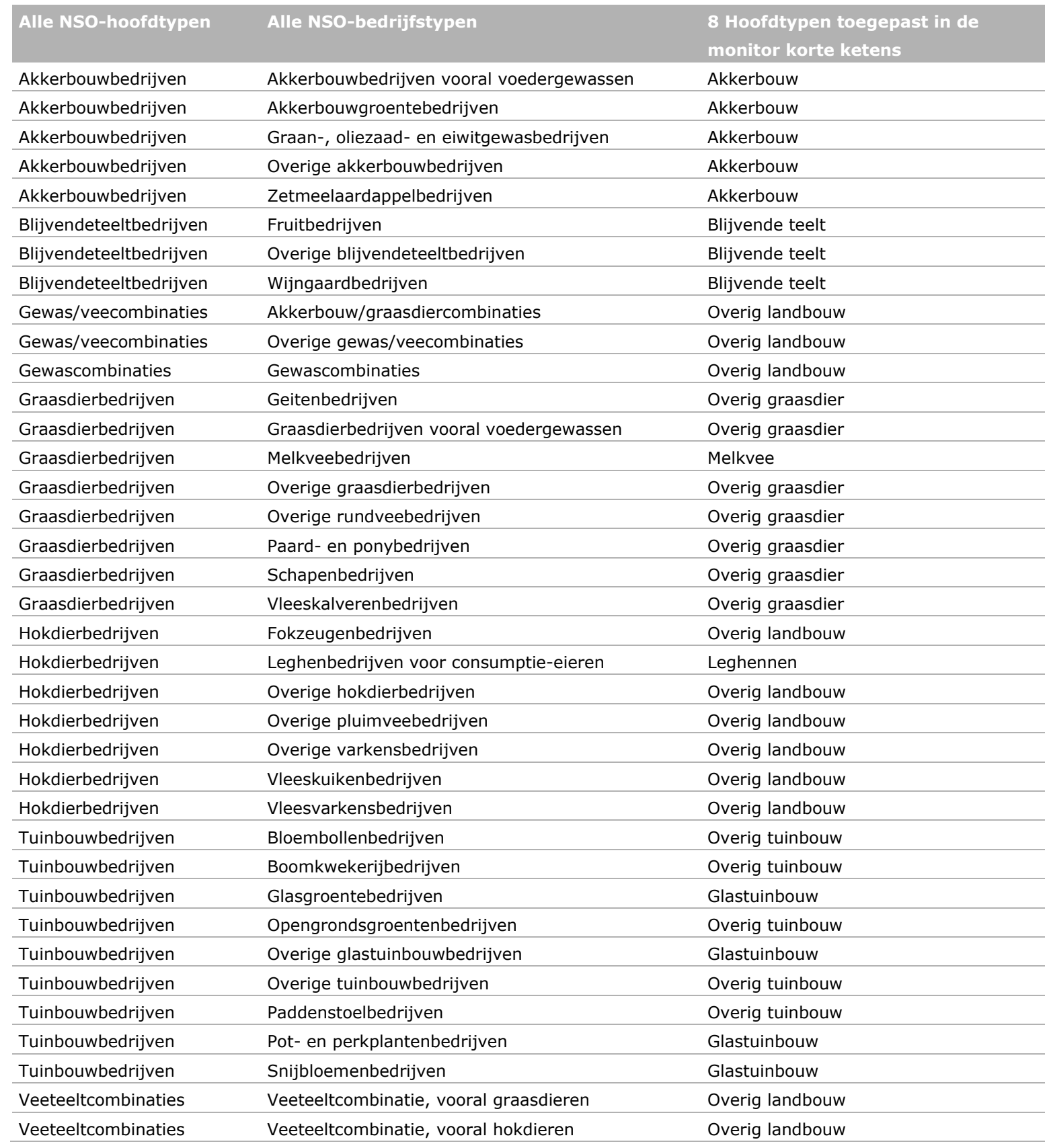




\section{Bijlage 3 Detaillering resultaten}

In de monitor korteketenbedrijven zijn de primaire agrarische bedrijven ingedeeld naar een achttal hoofdbedrijfstypen (zie bijlage 2). In deze bijlage worden meerdere resultaten per NSO-bedrijfstype weergegeven:

- Tabel B3.1: aantallen en aandeel korteketenbedrijven weergegeven voor alle NSO-bedrijfstypen

- Tabel B3.2: Aantal korteketenbedrijven, met rechtstreekse verkoop aan consument en verkoop via 1 tussenschakel, ingedeeld naar NSO-bedrijfstypen

- Figuur B3.1: Ontwikkeling in het percentage korteketenbedrijven per NSO-bedrijfstype, in 2017 en in 2020

- Figuur B3.2: Indeling agrarische bedrijven (met afzet via korte ketens) naar percentage van de omzet dat via een korte keten wordt verkregen, naar NSO-bedrijfstype, in Nederland (2000)

In deze bijlage ook:

Opbrengsten korte ketens in \% totaal opbrengsten

- Figuur B3.3. Verdeling korteketenbedrijven naar opbrengsten korte keten in \% totaal opbrensten, ingedeeld naar economische omvang in standaardverdiencapaciteit (SVC) in 2020

- Figuur B3.4. Verdeling korteketenbedrijven naar opbrengsten korte keten in \% totaal opbrensten, ingedeeld naar hoofdbedrijfstype, 2020

Regionale detaillering korte ketens

- Tabel B3.3 Agrarische bedrijven naar COROP-regio (alle bedrijven, korteketenbedrijven, percentage korte ketenbedrijven), 2020

- Tabel B3.4 Agrarische bedrijven naar provincie (alle bedrijven, percentage korteketenbedrijven), 2020 
Tabel B3.1 Indeling agrarische bedrijven naar NSO-bedrijfstype (aantallen alle bedrijven en korteketenbedrijven, percentage korteketenbedrijven), 2020

\begin{tabular}{|c|c|c|c|c|}
\hline NSO-hoofdbedrijfstype & NSO-bedrijfstype & $\begin{array}{r}\text { Aantal } \\
\text { bedrijven }\end{array}$ & $\begin{array}{r}\text { Aantal korte } \\
\text { keten } \\
\text { bedrijven }\end{array}$ & $\begin{array}{r}\% \text { korte } \\
\text { keten } \\
\text { bedrijven }\end{array}$ \\
\hline Akkerbouwbedrijven & Akkerbouwbedrijven met vooral voedergewassen & 2.716 & 108 & 4,0 \\
\hline Akkerbouwbedrijven & Akkerbouwgroentenbedrijven & 1.306 & 147 & 11,3 \\
\hline Akkerbouwbedrijven & Graan-, oliezaad- en eiwitgewasbedrijven & 810 & 31 & 3,8 \\
\hline Akkerbouwbedrijven & Overige akkerbouwbedrijven & 5.536 & 621 & 11,2 \\
\hline Akkerbouwbedrijven & Zetmeelaardappelbedrijven & 849 & 43 & 5,1 \\
\hline Blijvende teeltbedrijven & Fruitbedrijven & 1.345 & 581 & 43,2 \\
\hline Blijvende teeltbedrijven & Overige blijvende teeltbedrijven & 139 & 74 & 53,2 \\
\hline Blijvende teeltbedrijven & Wijngaardbedrijven & 42 & 33 & 78,6 \\
\hline Gewas-veecombinaties & Akkerbouw - graasdieren gecombineerd & 891 & 108 & 12,1 \\
\hline Gewas-veecombinaties & Overige gewas-veecombinaties & 571 & 150 & 26,3 \\
\hline Gewascombinaties & Gewascombinaties & 1.159 & 364 & 31,4 \\
\hline Graasdierbedrijven & Geitenbedrijven & 414 & 75 & 18,1 \\
\hline Graasdierbedrijven & Graasdierbedrijven met vooral voedergewassen & 732 & 51 & 7,0 \\
\hline Graasdierbedrijven & Melkveebedrijven & 14.572 & 1149 & 7,9 \\
\hline Graasdierbedrijven & Overige graasdierbedrijven & 564 & 70 & 12,4 \\
\hline Graasdierbedrijven & Overige rundveebedrijven & 4.722 & 618 & 13,1 \\
\hline Graasdierbedrijven & Paard- en ponybedrijven & 1.846 & 136 & 7,4 \\
\hline Graasdierbedrijven & Schapenbedrijven & 1.678 & 204 & 12,2 \\
\hline Graasdierbedrijven & Vleeskalverenbedrijven & 1.280 & 46 & 3,6 \\
\hline Hokdierbedrijven & Leghennenbedrijven voor consumptie-eieren & 551 & 284 & 51,5 \\
\hline Hokdierbedrijven & Overige hokdierbedrijven & 167 & 14 & 8,4 \\
\hline Hokdierbedrijven & Overige pluimveebedrijven & 403 & 25 & 6,2 \\
\hline Hokdierbedrijven & Overige varkensbedrijven & 596 & 41 & 6,9 \\
\hline Hokdierbedrijven & Vleeskuikenbedrijven & 507 & 45 & 8,9 \\
\hline Hokdierbedrijven & Vleesvarkensbedrijven & 1.241 & 52 & 4,2 \\
\hline Hokdierbedrijven & Zeugenbedrijven & 679 & 27 & 4,0 \\
\hline Tuinbouwbedrijven & Bloembollenbedrijven & 568 & 83 & 14,6 \\
\hline Tuinbouwbedrijven & Boomkwekerijbedrijven & 1.813 & 600 & 33,1 \\
\hline Tuinbouwbedrijven & Glasgroentebedrijven & 875 & 269 & 30,7 \\
\hline Tuinbouwbedrijven & Opengrondsgroentebedrijven & 853 & 329 & 38,6 \\
\hline Tuinbouwbedrijven & Overige glastuinbouwbedrijven & 282 & 50 & 17,7 \\
\hline Tuinbouwbedrijven & Overige tuinbouwbedrijven & 919 & 301 & 32,8 \\
\hline Tuinbouwbedrijven & Paddenstoelbedrijven & 115 & 43 & 37,4 \\
\hline Tuinbouwbedrijven & Pot- en perkplantenbedrijven & 679 & 223 & 32,8 \\
\hline Tuinbouwbedrijven & Snijbloemenbedrijven & 921 & 171 & 18.6 \\
\hline Veeteeltcombinaties & Veeteeltcombinatie, vooral graasdieren & 169 & 30 & 17,8 \\
\hline Veeteeltcombinaties & Veeteeltcombinatie, vooral hokdieren & 201 & 29 & 14,4 \\
\hline
\end{tabular}

Bron: Landbouwtelling, voorlopige cijfers 2020. 
Tabel B3.2 Aantal korteketenbedrijven, met rechtstreekse verkoop aan consument en verkoop via 1 tussenschakel, ingedeeld naar NSO-bedrijfstypen, 2020

\begin{tabular}{|c|c|c|c|}
\hline & Rechtstreeks & Via 1 tussenschakel a)I & Totaal via korte keten \\
\hline Akkerbouwbedrijven & 654 & 504 & 946 \\
\hline Akkerbouwbedrijven met vooral voedergewassen & 78 & 50 & 108 \\
\hline Graan-, oliezaad- en eiwitgewasbedrijven & 23 & 9 & 31 \\
\hline Overige akkerbouwbedrijven & 437 & 338 & 617 \\
\hline Blijvendeteeltbedrijven & 556 & 369 & 683 \\
\hline Fruitbedrijven & 458 & 312 & 577 \\
\hline Overige blijvende teeltbedrijven & 66 & 34 & 73 \\
\hline Wijngaardbedrijven & 32 & 23 & 33 \\
\hline Gewascombinaties & 286 & 181 & 365 \\
\hline Graasdierbedrijven & 1.605 & 1.252 & 2.362 \\
\hline Geitenbedrijven & 52 & 45 & 75 \\
\hline Graasdierbedrijven met vooral voedergewassen & 23 & 14 & 33 \\
\hline Melkveebedrijven & 713 & 670 & 1.146 \\
\hline Overige graasdierbedrijven & 76 & 48 & 105 \\
\hline Overige rundveebedrijven & 431 & 257 & 573 \\
\hline Paard- en ponybedrijven & 124 & 46 & 134 \\
\hline Schapenbedrijven & 150 & 158 & 252 \\
\hline Overige varkensbedrijven & 20 & 30 & 41 \\
\hline Vleeskuikenbedrijven & 27 & 28 & 45 \\
\hline Vleesvarkensbedrijven & 37 & 26 & 52 \\
\hline Zeugenbedrijven & 20 & 11 & 27 \\
\hline Tuinbouwbedrijven & 1.370 & 1.195 & 2.069 \\
\hline Bloembollenbedrijven & 45 & 49 & 83 \\
\hline Boomkwekerijbedrijven & 364 & 402 & 601 \\
\hline Glasgroentebedrijven & 170 & 161 & 269 \\
\hline Opengrondsgroentenbedrijven & 258 & 156 & 328 \\
\hline Overige glastuinbouwbedrijven & 42 & 28 & 55 \\
\hline Overige tuinbouwbedrijven & 236 & 158 & 307 \\
\hline Paddenstoelbedrijven & 24 & 33 & 46 \\
\hline Pot- en perkplantenbedrijven & 121 & 122 & 209 \\
\hline Snijbloemenbedrijven & 110 & 86 & 171 \\
\hline Veeteeltcombinaties & 49 & 18 & 58 \\
\hline Veeteeltcombinatie, vooral graasdieren & 22 & 9 & 28 \\
\hline Veeteeltcombinatie, vooral hokdieren & 27 & 9 & 30 \\
\hline
\end{tabular}

a) Een deel van de bedrijven dat rechtstreeks verkoopt aan de consument, doet dit eveneens via 1 tussenschakel.

b) Een deel van de bedrijven dat via 1 tussenschakel afzet aan de consument, verkoopt eveneens rechtstreeks.

Bron: Landbouwtelling. 


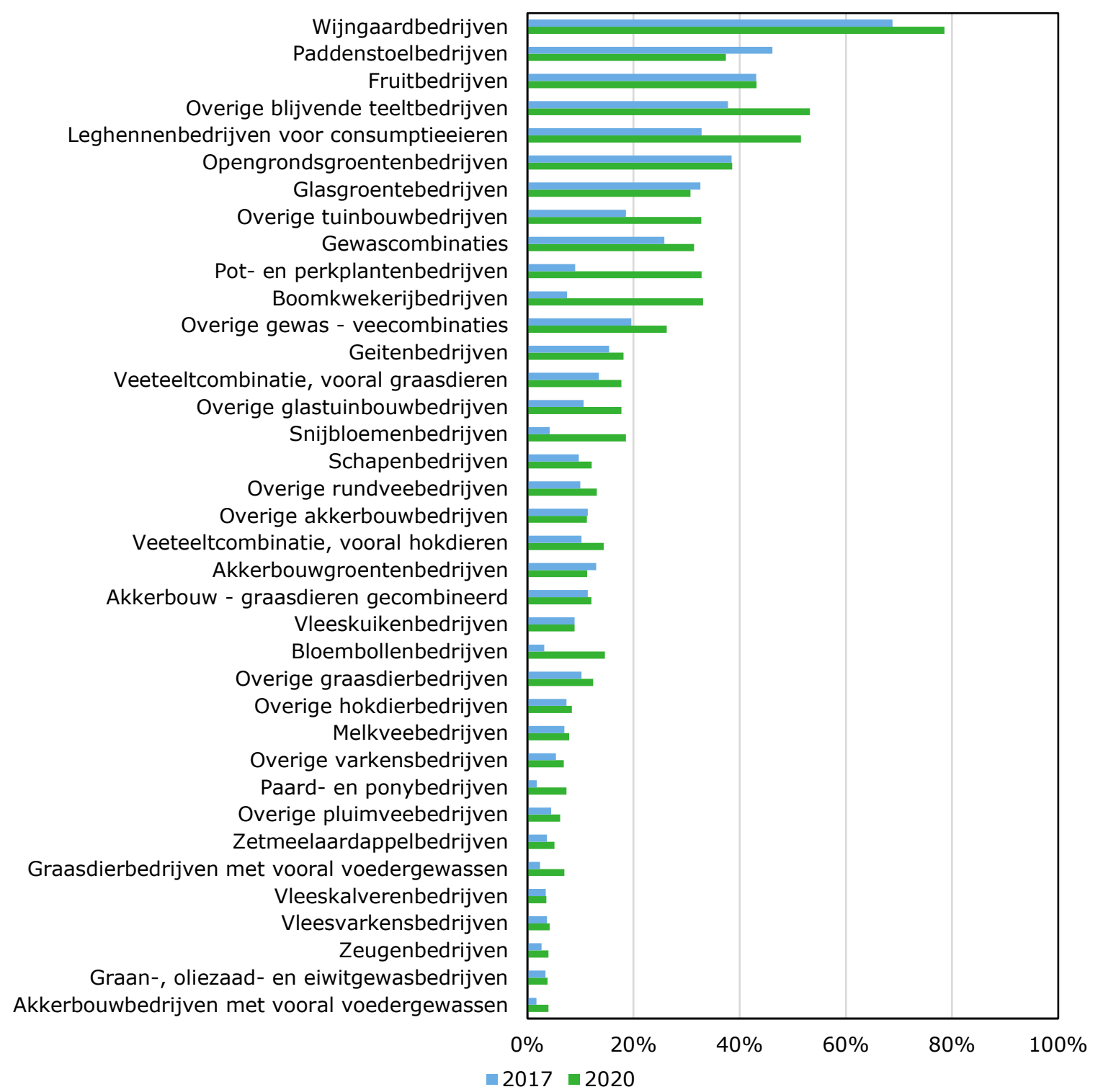

Figuur B3.1 Ontwikkeling in het percentage korteketenbedrijven per NSO-bedrijfstype, 2017 en 2020 Bron: Landbouwtelling (voorlopige cijfers 2020). 
Akkerbouw - graasdieren gecombineerd Akkerbouwbedrijven met vooral voedergewassen Akkerbouwgroentenbedrijven Bloembollenbedrijven Boomkwekerijbedrijven

Fruitbedrijven Geitenbedrijven

Gewascombinaties Glasgroentebedrijven Graan-, oliezaad- en eiwitgewasbedrijven Graasdierbedrijven met vooral voedergewassen Leghennenbedrijven voor consumptieeieren

Melkveebedrijven Opengrondsgroentenbedrijven Overige akkerbouwbedrijven Overige blijvende teeltbedrijven Overige gewas - veecombinaties Overige glastuinbouwbedrijven Overige graasdierbedrijven Overige hokdierbedrijven Overige pluimveebedrijven Overige rundveebedrijven Overige tuinbouwbedrijven Overige varkensbedrijven Paard- en ponybedrijven Paddenstoelbedrijven Pot- en perkplantenbedrijven Schapenbedrijven Snijbloemenbedrijven Veeteeltcombinatie, vooral graasdieren Veeteeltcombinatie, vooral hokdieren Vleeskalverenbedrijven Vleeskuikenbedrijven Vleesvarkensbedrijven Wijngaardbedrijven Zetmeelaardappelbedrijven Zeugenbedrijven

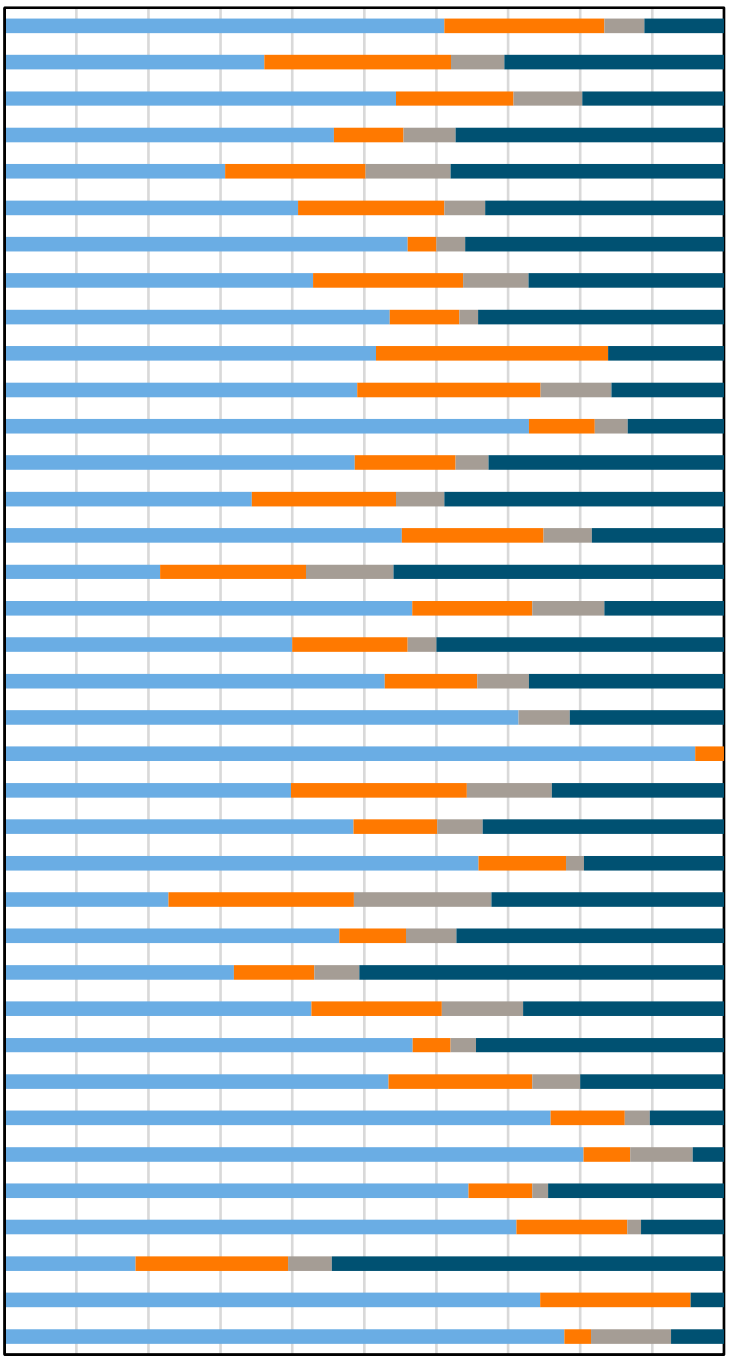

0\% 10\% 20\% 30\% 40\% 50\% 60\% 70\% 80\% 90\%100\%

$=<10 \% \quad-10-30 \% \quad-30-50 \% \quad->50 \%$

Figuur B3.2 Indeling agrarische bedrijven (met afzet via korte ketens) in Nederland naar percentage van de omzet dat via een korte keten wordt verkregen, naar NSO-bedrijfstype, 2000 Bron: Landbouwtelling (voorlopige cijfers 2020). 


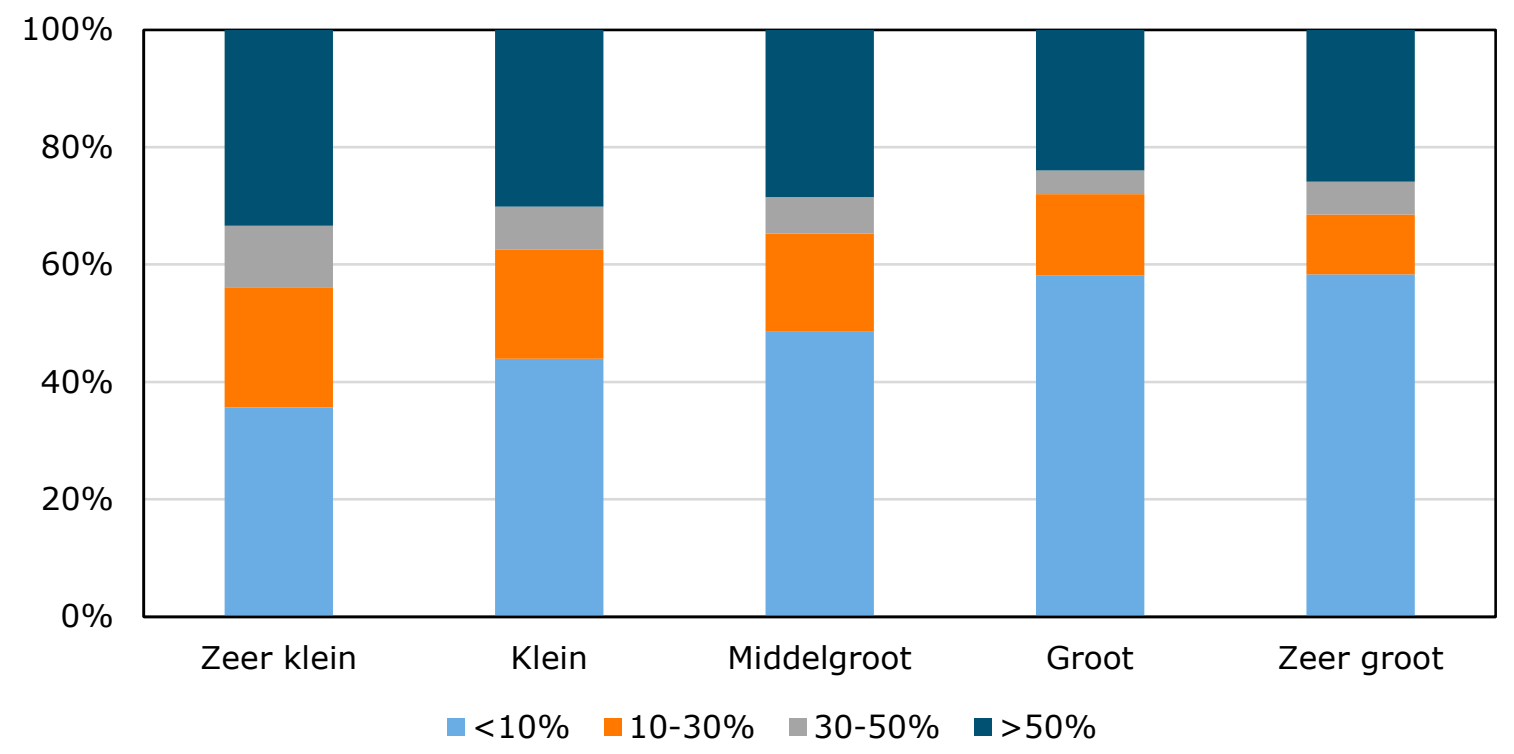

Figuur B3.3 Verdeling korteketenbedrijven naar opbrengsten korte keten in \% totaal opbrengsten, ingedeeld naar economische omvang in standaardverdiencapaciteit (SVC), 2020 Bron: Landbouwtelling, bewerking Wageningen Economic Research.

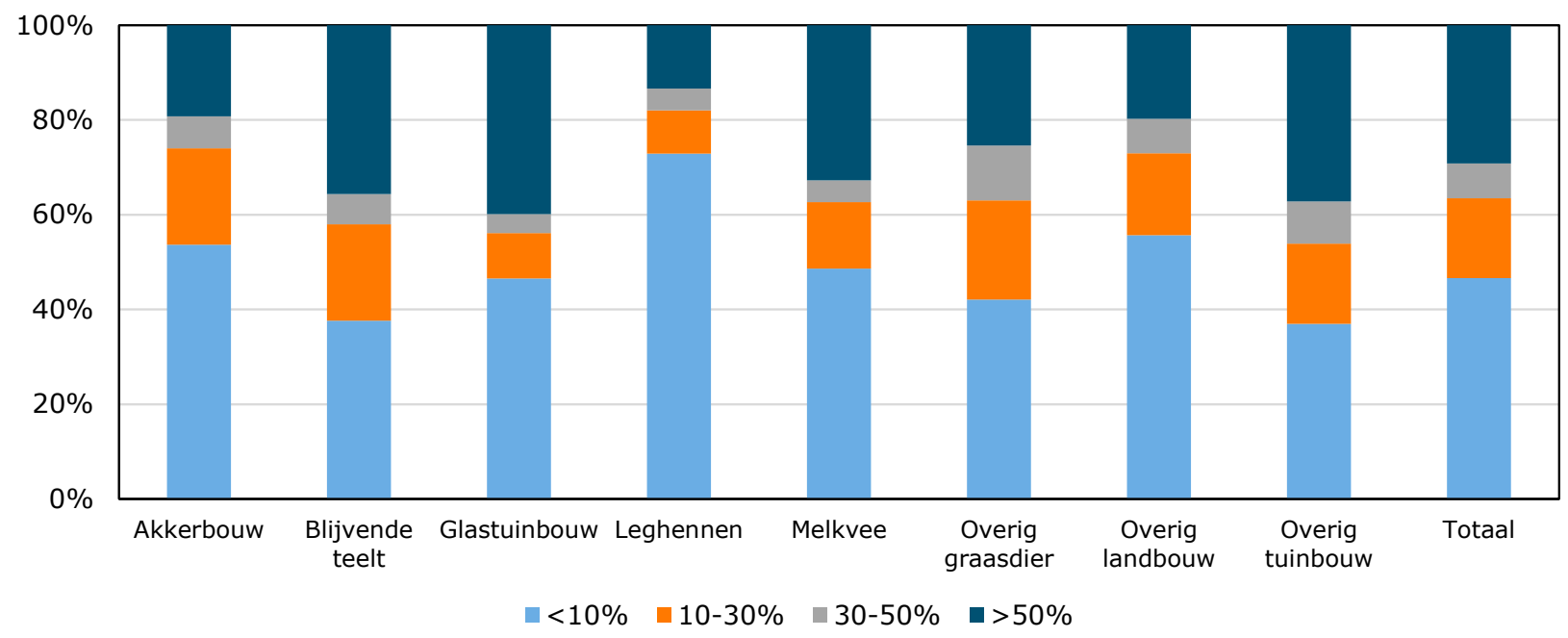

Figuur B3.4 Verdeling korteketenbedrijven naar opbrengsten korte keten in \% totaal opbrengsten, ingedeeld naar hoofdbedrijfstype, 2020

Bron: Landbouwtelling, bewerking Wageningen Economic Research. 
Regionale detaillering korte ketens: aantallen en \% korteketenbedrijven per COROP-gebied

Tabel B3.3 Agrarische bedrijven naar COROP-regio (alle bedrijven, korteketenbedrijven, percentage korte ketenbedrijven), 2020

\begin{tabular}{|c|c|c|c|c|}
\hline Provincie & COROP-regio & $\begin{array}{r}\text { Aantal agrarische } \\
\text { bedrijven }\end{array}$ & $\begin{array}{r}\text { Aantal korte } \\
\text { keten bedrijven }\end{array}$ & $\begin{array}{r}\% \text { korte } \\
\text { keten }\end{array}$ \\
\hline Drenthe & Noord-Drenthe & 981 & 136 & 13.9 \\
\hline Drenthe & Zuidoost-Drenthe & 951 & 85 & 8.9 \\
\hline Drenthe & Zuidwest-Drenthe & 828 & 99 & 12 \\
\hline Friesland & Noord-Friesland & 1.723 & 184 & 10.7 \\
\hline Friesland & Zuidoost-Friesland & 1.215 & 89 & 7.3 \\
\hline Friesland & Zuidwest-Friesland & 1.276 & 78 & 6.1 \\
\hline Groningen & Delfzijl en omgeving & 313 & 26 & 8.3 \\
\hline Groningen & Oost-Groningen & 713 & 67 & 9.4 \\
\hline Groningen & Overig Groningen & 1.490 & 151 & 10.1 \\
\hline Flevoland & Flevoland & 1.654 & 219 & 13.2 \\
\hline Gelderland & Achterhoek & 3.265 & 308 & 9.4 \\
\hline Gelderland & Arnhem/Nijmegen & 1.105 & 222 & 20.1 \\
\hline Gelderland & Veluwe & 2.814 & 292 & 10.4 \\
\hline Gelderland & Zuidwest-Gelderland & 1.670 & 317 & 19 \\
\hline Overijssel & Noord-Overijssel & 2.491 & 230 & 9.2 \\
\hline Overijssel & Twente & 3.200 & 247 & 7.7 \\
\hline Overijssel & Zuidwest-Overijssel & 957 & 89 & 9.3 \\
\hline Noord-Holland & Agglomeratie Haarlem & 17 & 6 & 35.3 \\
\hline Noord-Holland & Alkmaar en omgeving & 358 & 67 & 18.7 \\
\hline Noord-Holland & Groot-Amsterdam & 810 & 140 & 17.3 \\
\hline Noord-Holland & Het Gooi en Vechtstreek & 126 & 27 & 21.4 \\
\hline Noord-Holland & IJmond & 131 & 30 & 22.9 \\
\hline Noord-Holland & Kop van Noord-Holland & 1.895 & 363 & 19.2 \\
\hline Noord-Holland & Zaanstreek & 120 & 21 & 17.5 \\
\hline Utrecht & Utrecht & 2.338 & 334 & 14.3 \\
\hline Zeeland & Overig Zeeland & 1.575 & 322 & 20.4 \\
\hline Zeeland & Zeeuws-Vlaanderen & 1.198 & 129 & 10.8 \\
\hline Zuid-Holland & Agglom. Leiden/Bollenstreek & 596 & 131 & 22 \\
\hline Zuid-Holland & Agglom. 's-Gravenhage & 238 & 44 & 18.5 \\
\hline Zuid-Holland & Delft en Westland & 781 & 153 & 19.6 \\
\hline Zuid-Holland & Groot-Rijnmond & 1.313 & 292 & 22.2 \\
\hline Zuid-Holland & Oost-Zuid-Holland & 1.033 & 172 & 16.7 \\
\hline Zuid-Holland & Zuidoost-Zuid-Holland & 494 & 56 & 11.3 \\
\hline Limburg & Midden-Limburg & 1.136 & 222 & 19.5 \\
\hline Limburg & Noord-Limburg & 1.624 & 304 & 18.7 \\
\hline Limburg & Zuid-Limburg & 893 & 206 & 23.1 \\
\hline Noord-Brabant & Midden-Noord-Brabant & 1.487 & 211 & 14.2 \\
\hline Noord-Brabant & Noordoost-Noord-Brabant & 3.103 & 400 & 12.9 \\
\hline Noord-Brabant & West-Noord-Brabant & 2.113 & 455 & 21.5 \\
\hline Noord-Brabant & Zuidoost-Noord-Brabant & 2.670 & 310 & 11.6 \\
\hline
\end{tabular}

Bron: Landbouwtelling, voorlopige cijfers 2020. 
Tabel B3.4 Agrarische bedrijven naar provincie (alle bedrijven, percentage korteketenbedrijven), 2020

\begin{tabular}{l|rr} 
Provincie & Aantal bedrijven & Percenta \\
& 2754 & $11,6 \%$ \\
Drenthe & 1656 & $13,2 \%$ \\
Flevoland & 4204 & $8,3 \%$ \\
Friesland & 8861 & $12,8 \%$ \\
Gelderland & 2513 & $9,7 \%$ \\
Groningen & 3659 & $20,0 \%$ \\
Limburg & 9380 & $14,7 \%$ \\
Noord-Brabant & 3461 & $18,9 \%$ \\
Noord-Holland & 6637 & $8,5 \%$ \\
Overijssel & 2321 & $14,3 \%$ \\
Utrecht & 2776 & $16,2 \%$ \\
Zeeland & 4489 & $18,9 \%$ \\
Zuid-Holland & $\mathbf{5 2 7 1 1}$ & $\mathbf{1 3 , 7} \%$ \\
Totaal & &
\end{tabular}

Bron: Landbouwteling, voorlopige cijfers 2020. 
Wageningen Economic Research Postbus 29703

2502 LS Den Haag

T 0703358330

Ecommunications.ssg@wur.nl

www.wur.nl/economic-research

Wageningen Economic Research RAPPORT

2021-067
De missie van Wageningen University \& Research is 'To explore the potential of nature to improve the quality of life'. Binnen Wageningen University \& Research bundelen Wageningen University en gespecialiseerde onderzoeksinstituten van Stichting Wageningen Research hun krachten om bij te dragen aan de oplossing van belangrijke vragen in het domein van gezonde voeding en leefomgeving. Met ongeveer 30 vestigingen, 6.800 medewerkers (6.000 fte) en 12.900 studenten behoort Wageningen University \& Research wereldwijd tot de aansprekende kennisinstellingen binnen haar domein. De integrale benadering van de vraagstukken en de samenwerking tussen verschillende disciplines vormen het hart van de unieke Wageningen aanpak. 



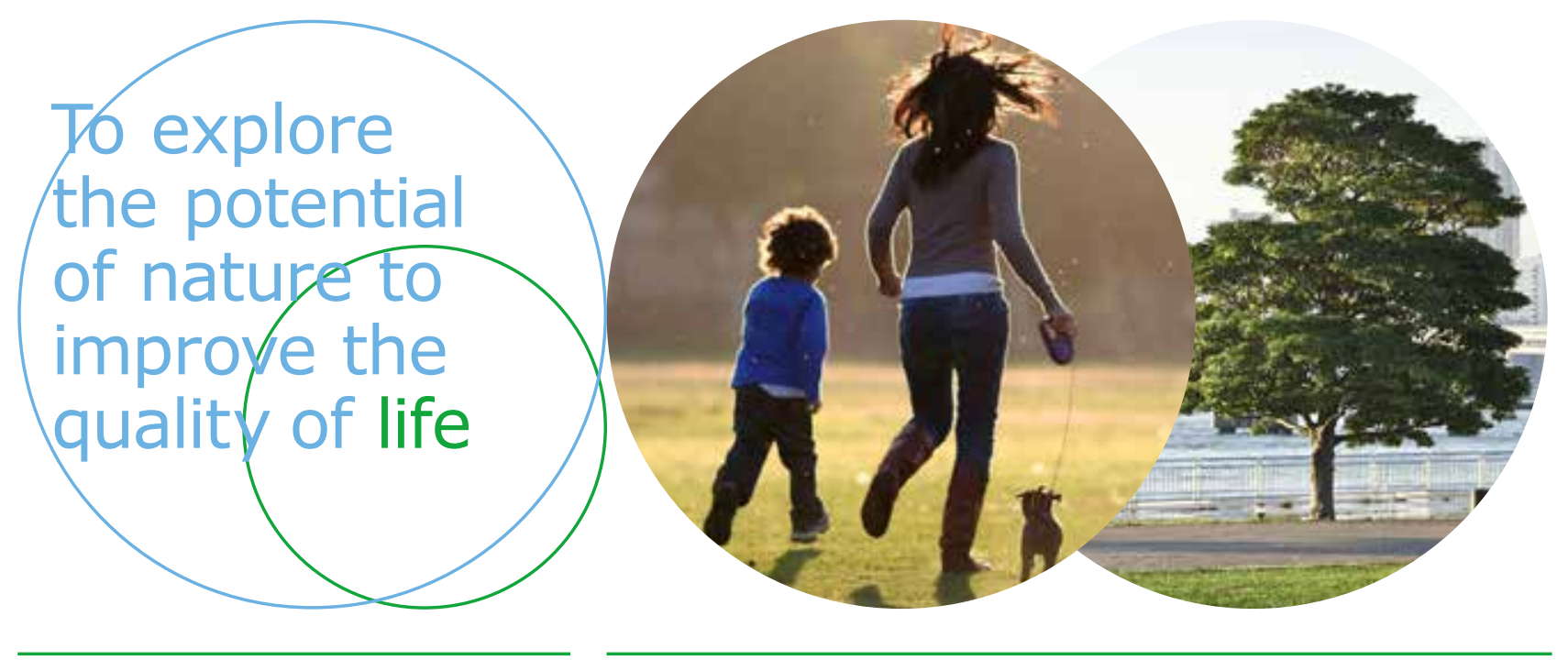

Wageningen Economic Research Postbus 29703

2502 LS Den Haag

T 0703358330

E communications.ssg@wur.nl www.wur.nl/economic-research

Rapport 2021-067

ISBN 978-94-6395-852-3
De missie van Wageningen University \& Research is 'To explore the potential of nature to improve the quality of life'. Binnen Wageningen University \& Research bundelen Wageningen University en gespecialiseerde onderzoeksinstituten van Stichting Wageningen Research hun krachten om bij te dragen aan de oplossing van belangrijke vragen in het domein van gezonde voeding en leefomgeving. Met ongeveer 30 vestigingen, 6.800 medewerkers ( $6.000 \mathrm{fte}$ ) en 12.900 studenten behoort Wageningen University \& Research wereldwijd tot de aansprekende kennisinstellingen binnen haar domein. De integrale benadering van de vraagstukken en de samenwerking tussen verschillende disciplines vormen het hart van de unieke Wageningen aanpak. 